\title{
Bounded Rationality, Standard Form Contracts, and Unconscionability
}

\author{
Russell Korobkin $\dagger$
}

Economic theory suggests that, in most circumstances, market forces will ensure that standard form contracts contain terms that are not only socially efficient but also beneficial to nondrafting parties as a class compared to other possible combinations of price and terms. This analysis in turn suggests that courts should enforce all form terms or, at a minimum, all form terms that non-drafting parties read and understand. Relying on social science research on decisionmaking, this Article argues that non-drafting parties (usually buyers) are boundedly rational decisionmakers who will normally price only a limited number of product attributes as part of their purchase decision. When contract terms are not among these attributes, drafting parties will have a market incentive to include terms in their standard forms that favor themselves, whether or not such terms are efficient. Thus, there is no a priori reason to assume form contract terms will be efficient. The Article then argues that the proper policy response to this conclusion is greater use of mandatory contract terms and judicial modification of the unconscionability doctrine to better respond to the primary cause of contractual inefficiency.

\section{INTRODUCTION}

More than thirty years ago, W. David Slawson estimated that 99 percent of all contracts did not resemble the Platonic ideal of a list of jointly negotiated terms but were instead presented by one party to the other on a pre-printed form.' If anything, the dominance of form contracts over negotiated contracts has increased in the intervening decades. The terms of mergers, joint ventures, and very large transactions are sometimes dickered, one at a time in the classic fashion, but nearly all commercial and consumer sales contracts are form driven. ${ }^{2}$ While a few terms-price often being one-might be negotiated on a

$\dagger$ Professor, UCLA School of Law. This Article benefited tremendously from the comments of workshop participants at the Max Planck Institute's Common Goods Project Group, the University of Pennsylvania Law School, the University of Southern California Law Center, and the University of Nevada-Las Vegas Boyd School of Law; as well as from Jennifer Arlen, Rachel Croson, Christoph Engel, Sam Fraidin, Chris Guthrie, Bentley MacLeod, Jeff Rachlinski, Dan Simon, Eric Talley, Tom Ulen, and Stephen Ware; and the research assistance of Heather Richardson and Dominik Sklenar.

1 W. David Slawson, Standard Form Contracts and Democratic Control of Lawmaking Power, 84 Harv L Rev 529, 529 (1971).

2 See, for example, Robert A. Hillman and Jeffrey J. Rachlinski, Standard-Form Contracting in the Electronic Age, 77 NYU L Rev 429, 435 (2002) ("People encounter standard forms in most of their contractual endeavors. ... [S]tandard forms govern [most] contractual relationships."). 
deal-by-deal basis, the boilerplate "fine print" usually specifies the breadth of the parties' obligations to one another, including, to use some prominent examples, terms that govern the extent of the seller's warranties, which party will bear the risk of various types of losses, the extent to which the buyer or seller may recover damages in the event of breach, and the type and location of forums available to resolve disputes between the parties. 'Such forms are often referred to as "contracts of adhesion," as one party presents the terms to the other on a take-it-or-leave-it basis with no opportunity for negotiation, although form terms are not necessarily adhesive and not all adhesive terms are presented on a pre-printed form."

Contract law generally provides for the enforcement of the terms in form contracts, thus essentially allowing the drafting party (almost always the seller in consumer contracts but sometimes the buyer in commercial contracts) to create its own private law to govern its transactions.' If the non-drafting party indicates his general assent to the form, courts will enforce the terms contained therein whether or not that party approves of the terms provided, understands those terms, has read them, or even has the vaguest idea what the terms might be about. Limited exceptions are made to this rule, most notably if the terms are found to be "unconscionable.",

The prevailing rule of form-term enforcement upsets many scholars, who recommend law reform. These critics decry the "unfairness"

3 In 1999, the New Jersey Law Revision Commission surveyed the terms of fifty common types of form contracts and determined that the following terms appeared with regularity and could potentially be abusive: (1) warranty; (2) damages; (3) attorneys' fees; (4) refund and repair; (5) indemnification; (6) risk of loss; and (7) waiver of rights. See John J.A. Burke, Contract as Commodity: A Nonfiction Approach, 24 Seton Hall Leg J 285, 293 (2000).

4 See, for example, Rudhart v North Jersey District Water Supply Commission, 127 NJ 344, 605 A2d 681, 685 (1992); Todd D. Rakoff, Contracts of Adhesion: An Essay in Reconstruction, 96 Harv L Rev 1174, 1177 (1983).

5 See Arthur Allen Leff, Unconscionability and the Code-The Emperor's New Clause, 115 U Pa L Rev 485, 505 (1967) (noting that a form contract is a symptom of adhesion but not its "essence").

6 See, for example, Graham v Scissor-Tail, Inc, 28 Cal 3d 807, 623 P2d 165, 172 (1981) (" $[\mathrm{A}]$ contract of adhesion is fully enforceable ... unless certain other factors are present which, under the established legal rules ... operate to render it otherwise."). For a more complete discussion of the exceptions to the rule, see Part IV.

7 See Slawson, 84 Harv L Rev at 536 (cited in note 1).

8 See Part IV. Courts occasionally invoke other related doctrines such as "reasonable expectations" or "public policy" to invalidate terms in form contracts, but to the extent that those doctrines relate specifically to form contract terms, they have for the most part either become part of unconscionability analysis or indistinguishable from it. Thus, these "related doctrines" are discussed along with unconscionability in Part IV.

9 See, for example, W. David Slawson, The New Meaning of Contract: The Transformation of Contracts Law by Standard Forms, 46 U Pitt L Rev 21, 23 (1984) (recommending that the reasonable expectations of the parties be enforced); Rakoff, 96 Harv L Rev at 1180-83 (cited in note 4) (arguing that form terms should be presumptively unenforceable); K.N. Llewellyn, Book Review, 52 Harv L Rev 700, 704 (1939) (arguing that unreasonable form terms should not be en- 
of the ability of drafting parties (hereinafter "sellers," although the drafting party is not always a seller) to impose adhesive terms on nondrafting parties (hereinafter "buyers" or "purchasers"). Two specific objections to the enforceability of terms embedded in form contracts are most plausible.

First, some critics argue that the enforcement of form terms is objectionable because it undermines individual autonomy, as the buyer finds herself obligated to terms to which she did not voluntarily agree. ${ }^{10}$ Freedom of contract demands freedom from contract, and just as no party has the ability to force another into a contract," no party should have the ability to force another party to accept specific terms. ${ }^{12}$

The problem with this argument is that, given the complexity of modern commerce, the alternative to form contracts is almost certainly not the resurgence of fully dickered, obligationally complete contracts, but rather law-imposed default terms invoked to fill gaps in the contract the parties negotiate. ${ }^{13}$ Actual assent to each contract term in a transaction of any complexity simply is not possible; if terms are not imposed on one party by the other, some terms will almost certainly be imposed on both parties by the government.

The alternative objection is consequentialist in nature: The routine enforcement of form terms results in contracts being less favorable to buyers than they otherwise would be. By seeding the "fine print" with pro-seller terms and then refusing to negotiate those terms, sellers capture more of the cooperative surplus created by the agreement than they would if terms were negotiated.

forced), reviewing O. Prausnitz, The Standardization of Commercial Contracts in English and Continental Law (Sweet and Maxwell 1937); Michael I. Meyerson, The Reunification of Contract Law: The Objective Theory of Consumer Form Contracts, 47 U Miami L Rev 1263, 1299 (1993) (claiming that consumers should be bound only to the terms they know and understand); Alex Y. Seita, Uncertainty and Contract Law, 46 U Pitt L Rev 75, 132 (1984) (proposing that contracts should be governed by default terms some of which may only be overcome when the disadvantaged party has given "intelligent and meaningful approval"); Jeffrey L. Harrison, Class, Personality, Contract, and Unconscionability, $35 \mathrm{Wm} \&$ Mary L Rev 445, 489 (1994) (calling for an "expanded notion of unconscionability" to prevent "uneven exchanges").

10 See, for example, Rakoff, 96 Harv L Rev at 1237 (cited in note 4) ("[E]nforcing boilerplate terms trenches on the freedom of the adhering party."); Slawson, 84 Harv L Rev at 530, 542 (cited in note 1) (stating that most standard form contracts do not embody the democratic consent of the parties). But see Charles Fried, Contract as Promise: A Theory of Contractual Obligation 1-2 (Harvard 1981) (arguing that preserving party autonomy should be the primary goal of contract law).

11 But see Hobbs v Massasoit Whip Co, 158 Mass 194, 33 NE 495, 495 (1893) (Holmes) (stating that a course of dealings between parties might change the background rule that a recipient of unrequested goods is not forced to return them or pay for them).

12 See, for example, Rakoff, 96 Harv L Rev at 1238 (cited in note 4) (arguing that a concern for the freedom of the adhering party "push[es] toward the conclusion that such terms should be completely unenforceable").

13 See, for example, id at $1246-47$. 
The problem with this argument is that standard law-andeconomics reasoning suggests that, if buyers and sellers behave in accordance with assumptions of rational choice theory, the operation of the market usually will provide drafting parties with an incentive to include only efficient terms in form contracts. ${ }^{14}$ Counterintuitively, a well-functioning market should ensure that buyers and sellers actually prefer the same contract terms. If they do, buyers are best served if courts enforce all terms in form contracts, even when those terms are adhesive. Consequently, to establish that form terms disadvantage buyers, and thus make out a prima facie case that a policy of routinely enforcing form terms is undesirable on that ground, a theory of market failure is required that explains why, contrary to the predictions of standard economic theory, sellers would have a profit incentive to place inefficient rather than efficient terms in form contracts.

This Article provides such a theory. Terms that govern the contractual relationship between buyers and sellers are attributes of the product in question, just as are the product's price and its physical and functional characteristics. Because buyers are boundedly rational rather than fully rational decisionmakers, when making purchasing decisions they take into account only a limited number of product attributes and ignore others. While sellers have an economic incentive to provide the efficient level of quality for the attributes buyers consider ("salient" attributes), they have an incentive to make attributes buyers do not consider ("non-salient" attributes) favorable to themselves, as doing so will not affect buyers' purchasing decisions. Assuming that price is always a salient product attribute for buyers, market competition actually will force sellers to provide low-quality non-salient attributes in order to save costs that will be passed along to buyers in the form of lower prices. Ironically, the consequence of market forces in a world of boundedly rational buyer decisionmaking is that contracts will often include terms that are socially inefficient, leave buyers as a class worse off (judged from the perspective of buyers' subjective preferences) ${ }^{15}$ than they would be if their contracts included only efficient terms, and leave sellers as a class worse off as well.

Courts can increase utility for buyers and sellers, as well as promote social efficiency, by enforcing efficient terms in form contracts and refusing to enforce inefficient terms. Courts' present use of unconscionability and related doctrines to strike objectionable terms

14 See Part I.A.

15 Although the argument can be made that individuals are incapable of determining what is best for them, and thus the paternalistic intervention of the state is appropriate. See, for example, Duncan Kennedy, Distributive and Paternalist Motives in Contract and Tort Law, with Special Reference to Compulsory Terms and Unequal Bargaining Power, 41 Md L Rev 563, 624-29 (1982). 
from form contracts is not well calibrated to produce this outcome, as the factual circumstances that trigger findings of unconscionability under the doctrine are, at best, weakly correlated with the main cause of inefficiency in form terms. By recognizing purchasers' bounded rationality as the most important root cause of inefficiency in form contracts, courts can modify their use of unconscionability analysis to increase both social welfare generally and buyer welfare specifically.

Courts' initial analytical step should be an analysis of whether a challenged contract term is salient to a significant number of buyers. When a contract term is salient to purchasers, the market can be trusted to provide an efficient version of the term: Absent fraud, duress, or significant third-party externalities, no judicial intervention is necessary. When a contract term is non-salient to most purchasers, the market check on seller overreaching is absent, and courts should be suspicious of the resulting term. Put slightly differently, whenever a term in a form contract is non-salient to most purchasers, those purchasers are incompetent to protect their interests vis-à-vis that term. In that situation, legislatures should mandate efficient terms ex ante when possible, and courts should police ex post for clearly inefficient terms.

This Article presents this argument in the following manner. Part I describes how, assuming basic postulates of economic analysis, the market should ensure that terms in form contracts are both socially efficient and desirable for both buyers as a class and sellers as a class. Without market failure, there is no valid consequentialist argument for non-enforcement of any contract terms, whether provided on a pre-printed form or offered on an adhesive basis.

Part II argues that the reason form terms deserve scrutiny is that buyers are not fully rational, but rather make decisions in a boundedly rational manner, and that this provides sellers with an incentive to draft non-salient contract terms to their own advantage, whether or not such terms are efficient.

Part III considers alternative conceptual approaches to policing the terms of form contracts in light of the incentives created by buyer bounded rationality. It concludes that ex ante legislative regulation of form contracts by promulgating mandatory terms should be a part of the response but cannot be the complete response. In addition, ex post regulation of form terms by courts is also necessary.

Part IV critically examines the doctrinal tools that courts currently use to police the enforcement of form contract terms-most prominently the unconscionability doctrine-and finds that current judicial doctrine is not well calibrated to the goal of mitigating the pernicious effects of form contracts. 
Part V provides specific recommendations for how courts can and should modify the unconscionability doctrine to better police inefficient form terms. It contends that (1) "procedural unconscionability" analysis should be motivated by an inquiry into a term's salience, (2) "substantive unconscionability" determinations should depend on whether terms are more costly to buyers than they are beneficial to sellers ex ante, (3) courts should require buyers to meet an exacting burden of proof before finding a term unconscionable under this criterion, and (4) courts should liberally refuse to enforce terms found unconscionable under this standard, and even refuse to enforce entire contracts on some occasions, in order to provide an incentive to sellers to draft efficient form contract terms ex ante when the market fails to provide such an incentive.

This Article concludes with brief discussions of whether "bounded rationality," as the term is used here, is or is not "rational" behavior and the importance of comparative institutional analysis in devising any legal policy response to bounded rationality in a variety of contexts.

\section{RATIONAL ACTORS AND FORM CONTRACT TERMS}

Economic analysis suggests that in a perfectly functioning market with complete information contracts between buyers and sellers will contain only efficient terms, ${ }^{16}$ defined as those for which the differential between benefits and costs is greatest, regardless of how distributed between buyers and sellers. " Economic theory also suggests that substituting an inefficient term into the contract would make both buyers and sellers worse off. ${ }^{18}$ The implication of these two propositions is that, in the absence of significant negative externalities to third parties, courts should never refuse to enforce contract terms, even if the terms are embedded in pre-printed forms and offered on an adhesive basis. To do so would be socially inefficient, and it would make buyers, as well as sellers, worse off than they otherwise would be." Sec-

16 See, for example, R. Ted Cruz and Jeffrey J. Hinck, Not My Brother's Keeper: The Inability of an Informed Minority to Correct for Imperfect Information, 47 Hastings L J 635, 638 (1996); Eric A. Posner, Contract Law in the Welfare State: A Defense of the Unconscionability Doctrine, Usury Laws, and Related Limitations on the Freedom to Contract, $24 \mathrm{~J}$ Legal Stud 283, 284 (1995).

17 For the definition of efficiency in this context, see Richard Craswell, Passing on the Costs of Legal Rules: Efficiency and Distribution in Buyer-Seller Relationships, 43 Stan L Rev 361, 363 (1991).

18 In economic language, terms for which the net marginal benefits outweigh the net marginal costs will be Pareto efficient as well as Kaldor-Hicks efficient.

19 See Hillman and Rachlinski, 77 NYU L Rev at 432 (cited in note 2) ("[F]ailure to enforce standard terms can harm both consumers and businesses."); Alan Schwartz and Louis L. Wilde, Imperfect Information in Markets for Contract Terms: The Examples of Warranties and Security Interests, 69 Va L Rev 1387, 1392-93 (1983) ("[A]ssuming a given distribution of wealth, 
tion A of this Part describes this reasoning-which relies fundamentally on the market discipline established by the ability of buyers to shop among sellers for the most desirable package of product attributes, including contract terms - in greater detail. ${ }^{20}$

Shopping among sellers, of course, is not costless for buyers: Shopping requires time and effort. Thus, some or all buyers might decide not to shop. However, relaxing the assumption of perfect information to take account of the fact that acquiring such information is costly does not, by itself, affect the conclusion that sellers will offer only socially efficient contract terms. Section B explains that if some or all buyers do not shop among multiple sellers, but, importantly, all buyers learn the contract terms offered by sellers that they do investigate and integrate that information into their purchase decisions, the unregulated market should still ensure that (a) sellers will provide only efficient terms and (b) refusal to enforce these terms would reduce the utility of both buyers and sellers.

\section{A. Perfect Information among Buyers}

1. Perfect competition, homogenous preferences.

Consider the following simple example, in which all widget sellers operate in a competitive market and buyers have identical preferences for contract terms, but not necessarily the underlying product:

Widget sellers must choose whether to include a complete warranty term (generically, "high quality") or a limited warranty term (generically, "low quality") in the contract that accompanies sales of their product. If sellers provide a high-quality warranty, rather than a low-quality warranty, their costs will increase by $\$ 10$ per widget. ${ }^{22}$ Buyers, for their part, enjoy the peace of mind of knowing that their widgets are fully warranted. They are willing to pay $\$ 15$ more for widgets that come with a high-quality warranty than for widgets that come with only a low-quality warranty.

In this example, all sellers will provide a high-quality warranty. ${ }^{23}$ If one seller ("Firm") were to provide a low-quality warranty but not re-

\footnotetext{
consumers cannot do better than purchase in competitive markets.").

20 Section A relies heavily on Craswell, 43 Stan L Rev 361 (cited in note 17).

21 Section B relies heavily on Schwartz and Wilde, 69 Va L Rev 1387 (cited in note 19).

22 If there is even the slightest possibility of widget malfunction, a full warranty is more costly to sellers than a limited warranty because a complete warranty term will require them to repair or replace at least some widgets.

23 See Schwartz and Wilde, 69 Va L Rev at 1398-99 (cited in note 19) ("[A]ssuming that consumers minimize net costs, firms maximize profits, and information is costless; sellers will offer optimally efficient warranty terms."). See also Alan Schwartz and Louis L. Wilde, Intervening in Markets on the Basis of Imperfect Information: A Legal and Economic Analysis, $127 \mathrm{U} \mathrm{Pa} \mathrm{L}$ Rev 630,640 (1979) (describing the Nash equilibrium in a "purely competitive market").
} 
duce its price, no buyers would choose to purchase from Firm. Even if Firm were to offer widgets at $\$ 10$ less than competitors and pass along the full $\$ 10$ it would save by providing the low-quality warranty, no buyers would choose to purchase from Firm, because any buyer that did so would save $\$ 10$ in cash but lose $\$ 15$ in value. Theoretically, Firm could market widgets with a low-quality warranty term successfully if it were to charge $\$ 15$ less than competitors that provided a highquality warranty. The cost of providing such a large discount, however, would bankrupt Firm; in a competitive market, by definition, sellers offering efficient terms at the market price make a sufficient profit to remain in business, but no more. ${ }^{24}$

If, in contrast, the high-quality warranty were worth only $\$ 5$ to buyers, no seller would provide a high-quality warranty. Doing so would cause Firm to either (a) lose all of its customers (if it were to increase its price by more than $\$ 5$ ) or (b) go bankrupt (if it were to increase its price by $\$ 5$ or less).

Note that whether the warranty term is adhesive is irrelevant to the analysis. For market forces to operate, it is not necessary for buyers to be able to negotiate with sellers over the content of the warranty term. It is only necessary for buyers to be able to shop amongst different firms. The threat of customers defecting to a competitor that offers the efficient warranty term will prohibit Firm from offering an inefficient warranty term - at least for very long. ${ }^{25}$

Because market pressure will force Firm to offer the efficient warranty term, courts should not refuse to enforce warranty terms, whether they turn out to be high or low quality. This is true regardless of whether courts favor efficiency (without regard to distribution) or buyers. ${ }^{26}$ To see why, assume again that buyers value a high-quality warranty at only $\$ 5$, but a court refuses to enforce a low-quality term, thus effectively mandating that all sellers provide a high-quality warranty. The judicial mandate will cause the widget industry's supply curve to shift upward by $\$ 10$ to reflect the increased cost of providing widgets at every quantity level. The mandate will also cause the consumer demand curve to shift upward because widgets are now more valuable. But the demand curve will shift up only $\$ 5$. The consequence of the supply curve shifting up by a greater amount than the demand

24 See, for example, James D. Gwartney and Richard L. Stroup, Economics: Private and Public Choice 67-68 (Dryden 7th ed 1995).

25 See Richard A. Posner, Economic Analysis of Law $\$ 4.8$ at 116 (Aspen 6th ed 2003) (stating that, in a competitive market, sellers will be forced to offer optimal form contract terms).

26 For a more detailed description of this important insight, see Craswell, 43 Stan L Rev at 369-72 (cited in note 17). See also Christine Jolls, Accommodation Mandates, 53 Stan L Rev 223, 237 (2000). 
curve is that the equilibrium price will increase by less than $\$ 10$ and equilibrium quantity will decline.

Less intuitively, each individual buyer will be worse off than he would have been with a low-quality warranty and a lower price. ${ }^{27}$ Marginal buyers - those who would have just barely been willing to buy a widget with a low-quality warranty - will choose not to buy a widget with a high-quality warranty, because the new price exceeds the total value to those buyers. (The exit of these buyers from the widget market is what causes equilibrium quantity to fall. $)^{28}$ These marginal buyers will be worse off if the courts mandate high-quality warranties because, by leaving the market, they will not capture the consumer surplus they would have enjoyed had they been permitted to purchase a widget with a low-quality warranty at the lower market price. Inframarginal buyers - those who would have enjoyed substantial consumer surplus (in this case, at least $\$ 5$ ) had they been permitted to buy a widget with a low-quality warranty - will still purchase widgets, but they will enjoy less consumer surplus than they would have had they been permitted to purchase a widget with a low-quality warranty for a lower price..$^{29}$ This is because, under the assumptions presented, the market price of widgets will increase by more than the $\$ 5$ that the high-quality warranty is worth to the inframarginal consumers.

\section{Monopoly sellers.}

Relaxing the assumption of perfect competition and instead assuming a single monopolist seller (or a small group of oligopolist sellers) does not affect the conclusions presented above: Sellers will still provide efficient terms in form contracts and buyers would be made worse off if courts were to refuse to enforce those terms. ${ }^{3.0}$ Although sellers with market power will capture some of the consumer surplus that buyers would enjoy under conditions of market competition, under reasonable assumptions," rational monopolists will offer the same non-price terms as would competitive sellers. ${ }^{32}$ By offering only terms

27 See Craswell, 43 Stan L Rev at 372 (cited in note 17).

28 Id at 369-70.

29 Id at 370.

30 See id at 369 ("[The assumption of perfect competition] is not very significant [to the analysis of the efficiency of terms], as the presence or absence of a monopoly seller would have little effect on most of the conclusions.").

31 The assumptions are that marginal and inframarginal buyers have the same preferences and that monopolist and competitive sellers have the same cost structure. For a more complete explanation, see Alan Schwartz, A Reexamination of Nonsubstantive Unconscionability, 63 Va L Rev 1053, 1071-76 (1977).

32 This is not to say that monopolies are efficient-only that when choosing between providing a high-quality and low-quality term, monopolists have a profit incentive to provide the high-quality term if and only if buyers value the high-quality term at a price greater than the 
that buyers value more than such terms cost to provide, sellers maximize the willingness of buyers to pay relative to the costs of production. By first providing efficient terms and then raising price above its competitive-market level, sellers can maximize total profits."

Assume again that the cost to sellers of providing a high-quality warranty exceeds the cost of providing a low-quality warranty by $\$ 10$ per widget, and that buyers value the marginal benefits of a highquality warranty at $\$ 15$ per widget (thus, a high-quality warranty would be efficient). A monopolist seller has two options. It can provide a low-quality warranty and save $\$ 10$ in production costs. If it does this, however, there will be fewer buyers willing to purchase widgets at any price the seller might set. Even when the seller is a monopolist, buyers have the option of not purchasing the goods or services in question. ${ }^{34}$ Alternatively, the seller can provide a high-quality warranty. This will increase its production costs by $\$ 10$, but it will also significantly increase the quantity of widgets sold at any price because the widgets are now more valuable to buyers. As long as high-quality warranties are efficient - that is, value to buyers exceeds cost to sellersthe monopolist can maximize profits by offering a high-quality warranty, rather than by offering a low-quality warranty.

\section{Heterogeneous buyers.}

To this point, the analysis has assumed that all buyers place the same value on a high-quality term. In the real world, of course, buyers often will have heterogeneous preferences for contract terms. This creates two complications for the basic economic model. First, a term that is efficient for some buyers may not be efficient for all buyers. Second, a court's refusal to enforce some form terms could make some buyers better off than they would otherwise be.

Imagine two buyers: Customer A values a high-quality warranty at $\$ 15$ more than a low-quality warranty, whereas Customer $B$ values

marginal cost to the seller of providing it.

33 See, for example, Eric A. Posner, Economic Analysis of Contract Law after Three Decades: Success or Failure?, 112 Yale L J 829, 843 (2003) ("[G]enerally the most efficient way [for sellers] to exploit market power is through the price term."); Kennedy, $41 \mathrm{Md} \mathrm{L} \mathrm{Rev} \mathrm{at} 608$ (cited in note 15) ("[E]ven a monopolist has an interest in providing contract terms if buyers will pay him their cost, plus as much in profit as he can make for alternative uses of his capital."); Cruz and Hinck, 47 Hastings $\mathrm{L} \mathrm{J}$ at 638 (cited in note 16) (Efficient terms are obtainable "even if the seller is a monopolist, because a perfectly informed consumer would accurately value all contract terms, and a rational monopolist would simply extract monopoly profits directly through the price.") (footnote omitted); George L. Priest, A Theory of the Consumer Product Warranty, 90 Yale L J 1297, 1321 (1981) ("[M]onopoly profits are maximized by selling a product identical in all respects (except price) to the product offered under competition."); Avery Weiner Katz, Standard Form Contracts, in Peter Newman, ed, 3 The New Palgrave Dictionary of Economics and the Law 502, 502 (Macmillan 1998).

34 See Posner, Economic Analysis of Law $\$ 4.8$ at 116 (cited in note 25). 
the extra protection at only $\$ 5$. If high-quality warranties cost sellers $\$ 10$ more to provide, a high-quality warranty is by definition efficient for Customer A, but not for Customer B. Assume that the seller cannot discriminate between the two types of customers, as is usually the case in consumer transactions and often the case even in business-tobusiness transactions. By definition, when a seller offers a single form contract it cannot discriminate between buyers; it must offer the same term to all. Whichever type of warranty term a seller chooses to offer will be efficient for Customer A and inefficient for Customer B, or vice versa.

If Customer A types and Customer B types are distributed randomly among the class of buyers ${ }^{35}$ and there is a single monopolist seller, the seller will maximize profit by choosing to provide the warranty that is efficient for the most customers. This might be said to be the globally efficient term, given the constraint that it is impractical for the seller to offer different warranty terms to different customers. If a court refused to enforce the market-created warranty term, thus effectively mandating that sellers provide the opposite term, the majority of resulting contracts would be inefficient and the majority of buyers made worse off, although some buyers would be made better off.

If there is a competitive market with many sellers, market forces should cause some sellers to offer a high-quality warranty at a higher price, efficient for, and thus appealing to, Customer A types, and other sellers to offer a low-quality warranty at a lower price, efficient for, and thus appealing to, Customer B types. ${ }^{36}$ In a competitive market, then, all contracts should be efficient. If a court refused to enforce the low-quality warranty term, contracts that would otherwise include a low-quality warranty term would be rendered inefficient, and the buyers who would have selected sellers offering a low-quality warranty term would be made worse off.

35 The analysis becomes more complicated-and more complicated than is necessary for this Article - if marginal buyers have systematically different preferences for warranties than inframarginal buyers, or, for that matter, if marginal and inframarginal sellers have systematically different cost structures for providing warranties. For general discussions, see Craswell, $43 \mathrm{Stan} \mathrm{L}$ Rev at 377-83 (cited in note 17); Kennedy, $41 \mathrm{Md} \mathrm{L} \mathrm{Rev} \mathrm{at} \mathrm{610-12} \mathrm{(cited} \mathrm{in} \mathrm{note} \mathrm{15).} \mathrm{For} \mathrm{a} \mathrm{par-}$ ticular application in the context of housing, see Bruce Ackerman, Regulating Slum Housing Markets on Behalf of the Poor: Of Housing Codes, Housing Subsidies and Income Redistribution Policy, 80 Yale L J 1093 (1971).

36 See Priest, 90 Yale $\mathrm{L} \mathrm{J}$ at 1347 (cited in note 33) (claiming that if consumers have heterogeneous preferences firms should offer different warranties, and reporting empirical evidence supporting this claim). 


\section{B. Shopping as a Costly Activity}

The analysis above assumes that buyers have costless access to information about the terms provided in each seller's form contract, such that the terms sellers offer will be constrained by the implicit threat that buyers will purchase from a competitor if one provides a more desirable package of product attributes, including contract terms. Information about sellers' contract terms is costly to obtain, however, and buyers might rationally choose not to shop amongst multiple sellers if the costs of doing so exceed the expected benefits. Different buyers are likely to have different opportunity costs of shopping and to receive different amounts of positive or negative utility from the activity as well. Thus, in any particular product market, some buyers might shop multiple sellers, while others shop only a single seller. Whether all buyers, no buyers, or some buyers shop among multiple sellers, however, economic reasoning predicts that all sellers will still retain an incentive to offer efficient contract terms. This section explains this reasoning.

\section{All buyers shop.}

Assume first that shopping amongst multiple sellers has a positive cost, but the cost is relatively small (perhaps shopping can be done quickly on the internet or buyers enjoy browsing in multiple stores). As a result, all buyers shop multiple sellers before determining whether and from whom to purchase a widget.

In this situation, sellers should behave as they were expected to behave in section $\mathrm{A}$, when it was assumed that buyers had costless access to the product attributes of all sellers. Sellers will offer the efficient terms at a competitive price. Sellers that offer inefficient terms (at a competitive price given those terms) or efficient terms (at a supracompetitive price) will lose customers to competitors and will face the choice of quickly changing their behavior or going out of business.

\section{No buyers shop.}

Assume now that shopping is an extremely costly activity for buyers, such that no buyers shop among multiple sellers. Instead, each buyer interested in a widget visits a single seller, learns about the product attributes (including contract terms) offered by that seller, and then decides whether to purchase the widget or do without.

In this situation, each seller is effectively a monopolist relative to each buyer who considers that seller's widgets, and sellers should de-

37 For a general discussion, see George J. Stigler, The Economics of Information, $69 \mathrm{~J}$ Polit Econ 213 (1961). 
termine contract terms and price as would any other monopolist. That is, each seller should offer the efficient set of contract terms and charge a supracompetitive price designed to maximize profits. ${ }^{3 .}$ Should a seller offer inefficient terms, it either will earn less profit per widget sold (because the difference between the cost of producing the widget and buyers' willingness to pay declines), or, if it attempts to reap the same amount of profit per widget, it will sell fewer widgets (because the price will exceed the maximum that more buyers are willing to pay).

\section{Some buyers shop.}

Finally, assume that some buyers decide to spend the resources necessary to shop multiple widget sellers, while other buyers choose to shop only a single seller. In most markets, this is the most realistic assumption. ${ }^{39}$ In this situation, each seller faces a competitive market relative to the "shoppers," but is a monopolist relative to the "nonshoppers" who choose to investigate only its widgets.

Assuming that the seller cannot discriminate between shoppers and non-shoppers, it must offer a single set of terms, including price, to all buyers. If it wishes to appeal to shoppers, the seller will offer efficient terms and a competitive price. This will maximize sales, but the seller will earn less profit per non-shopper than it potentially could earn. If the seller instead targets non-shoppers, it will offer efficient terms at a monopoly price, thus maximizing its revenue from nonshoppers but forfeiting potential sales to shoppers, who will buy elsewhere. Which of these two strategies is optimal depends on two factors: the percentage of shoppers versus non-shoppers ${ }^{41}$ and the size of the potential monopoly profits that can be earned from sales to the non-shoppers. Since sellers might have different production costs and a different mix of shoppers and non-shoppers, all sellers may not adopt the same strategy.

38 See Part I.A.2.

39 See Schwartz and Wilde, 127 U Pa L Rev at 648 (cited in note 23) (concluding from studies that in a variety of markets some, but not all, customers shopped at more than one store before making a purchase).

41) Notice that because shopping is costly to (most) shoppers and creates benefits for nonshoppers by reducing the likelihood that sellers will deem it desirable to set prices at monopoly levels, shoppers might choose to free-ride on the beneficial actions of other shoppers while avoiding the costs of shopping themselves, meaning that shopping is an activity that the market as a whole is likely to inefficiently underproduce. See Hillman and Rachlinski, 77 NYU L Rev at 447 (cited in note 2 ).

41 If some, but not all, customers shop, prices will be distributed from the competitive price to the monopoly price. If the number of shoppers is significant, prices will cluster toward the competitive level. If there are few shoppers, prices will cluster toward the monopoly level. See Schwartz and Wilde, $127 \mathrm{U}$ Pa L Rev at 650 (cited in note 23). 
Whichever strategy, or mix of strategies, sellers select, however, they will have an incentive to offer efficient non-price terms. Monopolistic pricing strategies will be worse for shoppers than competitive pricing strategies, of course, since the former will result in marginal non-shoppers deciding not to purchase widgets and inframarginal non-shoppers paying more for widgets than they otherwise would. But buyers as a class could not be made better off if courts refused to enforce the non-price terms offered by sellers. ${ }^{42}$

\section{Conclusion}

Standard economic reasoning suggests that form contract terms provided by sellers should be socially efficient. Less obviously, economic reasoning also leads to the conclusion that those terms will be beneficial to buyers as a class, in the sense that buyers would prefer the price/term combination offered by sellers to any other economically feasible price/term combination. These conclusions are valid whether all, some, or no buyers shop multiple sellers for the best combination of product attributes and whether the market is competitive or dominated by a monopolist seller. ${ }^{43}$ From a consequentialist perspective, then, a policy preference for courts to enforce all terms in form contracts drafted by sellers appears not only plausible, but practically required. ${ }^{44}$ Any persuasive argument against the enforcement of form contract terms must begin by challenging the behavioral assumptions that underlie economic theory. Specifically, some form of "market failure" must be identified. Part II does just this.

\section{Bounded Rationality AND PRoduct CHOICE}

The "rational choice" assumptions of economics, and the implications that flow logically from those assumptions, suggest that the market, not state intervention, will ensure the provision of contract terms that are socially efficient and optimal for buyers as a class. From this perspective, the state's refusal to enforce terms provided in form contracts, either as a result of ex ante legislation or case-by-case judicial analysis, threatens to make the world a worse place-measured from

42 If buyers have heterogeneous preferences for terms, of course, it is possible that terms offered by sellers will be inefficient for some buyers, and thus that a court determination not to enforce those terms would make those buyers better off.

43 Although a monopolist will offer an inefficiently high price, buyers will prefer the price/term combination offered voluntarily by the monopolist to the price/term combination whose terms were regulated.

44 As noted in the Introduction, even a libertarian argument against the enforcement of form terms would be difficult to defend, since any practical alternative would require courts to impose gap-filling terms on both parties that were drafted or proposed by neither. 
either a perspective of social efficiency or buyer welfare-than a regime in which all form terms are enforced.

Over the years, commentators have routinely observed that buyers often fail to read the terms in standard form contracts, ${ }^{45}$ and some have argued that a failure to read could theoretically prevent markets from guaranteeing the production of efficient form terms. ${ }^{46}$ This critique of form contracts, while correct as far as it goes, suffers from two shortcomings. The first is that it raises but does not answer the question of why buyers seem to read form contract terms rarely, if ever. The second is that the failure-to-read critique implies that resulting market failures would disappear if buyers were to read form terms or if other institutions mediated the communication of the information in those terms to buyers - in other words, the principal problem is one of information acquisition.

This Part draws on research in the fields of judgment and decisionmaking and consumer behavior to argue that the fundamental cause of inefficient terms in form contracts lies in the boundedly rational approaches buyers use to evaluate information and make choices in the marketplace. ${ }^{48}$ Efficiency requires not only that buyers

45 See, for example, Rakoff, 96 Harv L Rev at 1179 (cited in note 4) (claiming that "[v]irtually every scholar who has written about contracts of adhesion" accepts the claim that "the adhering party is in practice unlikely to have read the standard terms"); Cruz and Hinck, 47 Hastings L J at 635-36 (cited in note 16) ("[F]ine-print terms are frequently not read by those that sign the contracts."); Burke, 24 Seton Hall Leg J at 299 (cited in note 3) ("Courts know that parties sign or manifest assent to standard form contracts that they have not read, understood or negotiated."). There appears to be little direct empirical data on this point. One court recently reported that AT\&T found that only 30 percent of its customers would read its entire form agreement updating contract terms, 10 percent would not read it at all, and 25 percent would throw away the mailing without even opening it. Ting $v A T \& T, 182 \mathrm{~F}$ Supp 2d 902, 930 (ND Cal 2002). A related argument is that adhering parties, especially consumers, will find it irrational to bear both the "search and deliberation" costs necessary to understand the form terms. See Melvin Aron Eisenberg, The Limits of Cognition and the Limits of Contract, 47 Stan L Rev 211, 243-44 (1995).

46 See, for example, Slawson, 84 Harv L Rev at 530-31 (cited in note 1) (claiming form terms will be inefficient and unfair because consumers do not read them); Lee Goldman, $M y$ Way and the Highway: The Law and Economics of Choice of Forum Clauses in Consumer Form Contracts, 86 Nw U L Rev 700, 716-21 (1992) (arguing that the economic model is flawed because consumers are unlikely to read form terms or understand the terms they do read); Michael I. Meyerson, The Efficient Consumer Form Contract: Law and Economics Meets the Real World, 24 Ga L Rev 583, 595 (1990) ("[I]nefficient transactions occur because consumers do not read form contracts, or do not understand their terms."); Victor P. Goldberg, Institutional Change and the Quasi-Invisible Hand, 17 J L \& Econ 461, 485 (1974) (stating that unless firms advertise the content of terms, sellers will compete on price rather than terms).

47 See, for example, Katz, Standard Form Contracts at 504 (cited in note 33) (noting that asymmetric information can result in inefficient terms in form contracts); Meyerson, $24 \mathrm{Ga} \mathrm{L}$ Rev at 585 (cited in note 46) ("[I]mperfect consumer information causes a tendency toward inefficiency in transactions involving consumer form contracts."); Eisenberg, 47 Stan L Rev at 241 (cited in note 45) (blaming the "phenomenon of rational ignorance" for problems with form contracts).

48 Despite the central importance to the subject of contract law of how buyers select prod- 
be aware of the content of form contracts, but also that they fully incorporate that information into their purchase decisions. Because buyers are boundedly rational rather than fully rational decisionmakers, they will infrequently satisfy this requirement. The consequence is that market pressure will not force sellers to provide efficient terms. In addition, under plausible assumptions, market pressure actually will force sellers to provide low-quality form terms, whether or not those terms are either socially efficient or optimal for buyers as a class. This Part further describes these positive conclusions. Subsequent Parts consider potential policy responses.

\section{A. The Behavioral Assumptions of Cost-Benefit Analysis}

The economic theory of form contracts, as described above, assumes a type of "rational" behavior" on the part of buyers, often referred to as "expected utility theory," according to which buyers are expected to use the marketplace to maximize their expected utility as they define it." This behavioral assumption seems unobjectionable at its simplest level: namely, that different individuals have different goals, but all will attempt to satisfy their goals as cheaply as possible. Lurking beneath the surface of the utility-maximization assumption, however, are stringent assumptions about the human decisionmaking processes that are difficult to defend. This section describes these assumptions.

ucts, this literature has rarely been explored in the contract law literature. Two exceptions are Russell Korobkin, The Efficiency of Managed Care "Patient Protection" Laws: Incomplete Contracts, Bounded Rationality, and Market Failure, 85 Cornell L Rev 1 (1999), and David M. Grether, Alan Schwartz, and Louis L. Wilde, The Irrelevance of Information Overload: An Analysis of Search and Disclosure, 59 S Cal L Rev 277 (1986).

49 The concept of rationality often means somewhat different things to different scholars. For a typology, see Russell B. Korobkin and Thomas S. Ulen, Law and Behavioral Science: Removing the Rationality Assumption from Law and Economics, $88 \mathrm{Cal} \mathrm{L}$ Rev 1051, 1060-70 (2000).

50) See id at 1062-64.

51 See, for example, Gary S. Becker, The Economic Approach to Human Behavior 4 (Chicago 1976) (stating that the "maximizing behavior" assumptions are "at the heart of the economic approach"). The classic theory of consumer choice is consistent with this assumption. See, for example, James R. Bettman, Mary Frances Luce, and John W. Payne, Constructive Consumer Choice Processes, 25 J Consumer Rsrch 187, 187 (1998) (claiming that rational choice assumptions have "contributed greatly to the prediction of consumer decisions"); Ravi Dhar, Consumer Preference for a No-Choice Option, 24 J Consumer Rsrch 215, 216 (1997) ("[T]he classical theory of choice assumes that ... information processing is costless."); Eric J. Johnson and Robert J. Meyer, Compensatory Choice Models of Noncompensatory Processes: The Effect of Varying Context, $11 \mathrm{~J}$ Consumer Rsrch 528, 528 (1984) (observing that in most consumer choice analysis, "consumers are hypothesized to choose the option with the highest overall utility or value"); Peter Wright, Consumer Choice Strategies: Simplifying vs. Optimizing, 12 J Marketing Rsrch 60,61 (1975) (noting that "a common assumption has been that [the consumer] picks the option offering [the] highest utility"). 
The argument that an unregulated market will produce efficient contract terms, as described in Part I, assumes that buyers will always make purchasing decisions that maximize their expected utility, at least given the choices presented. By comparison shopping, buyers will identify the widget with the combination of attributes, including terms and price, that maximizes their utility. ${ }^{52}$ This behavior in turn disciplines sellers, forcing them to offer combinations of product attributes, including terms and price, that buyers most desire. Buyers obviously will refuse to buy from sellers that offer a low-quality widget at a high price. But buyers will also abandon sellers that offer a high-quality widget at a high price if the buyers do not value the high quality at the cost of producing it, and they will abandon sellers that offer a low price if the attendant product quality is lower than that for which they are willing to pay.

Non-shoppers have a more limited set of choices. They must choose between the widget offered by the single seller that they visit and the option of not purchasing a widget at all. But between these two choices, buyers are expected to select the one that maximizes their utility. That is, they are expected to purchase the widget if doing so would provide them with more utility than any alternative use of the money that the widget would cost but not if that money could otherwise provide more utility.

Put more simply, the standard economic model assumes buyers will conduct a thorough cost-benefit analysis of product choices (including the choice of purchasing no product) and select the one that offers the optimal (that is, most desirable) combination of attributes, including price. Such exacting buyer behavior drives out of the market all products with undesirable attributes and all products with attributes that are desirable but cost more to produce than buyers are willing to pay. Products that remain have the optimally efficient combination of attributes, at least for a segment of buyers that is large enough to support the minimum effective scale of production."

52 But see Schwartz and Wilde, 69 Va L Rev at 1389 (cited in note 19) (recognizing that their analysis and conclusions rest on the assumption that "consumers always know what their contracts say"- a necessary precondition to making an expected utility calculation).

53 Notice that the results of the standard economic model do not depend on as heroic assumptions about seller behavior as they do about buyer behavior. For the model's results to occur, sellers must attempt to maximize their profits, but to accomplish this they need not have perfect information ex ante about how to do so. The buyers' choices provide sellers with constant feedback. A seller that initially fails to offer a combination of product attributes that is optimal for a substantial number of buyers will have few, if any, customers-a result that will serve as instant notification of its mistake and provide an opportunity to make necessary adjustments. Thus, this Article focuses on the boundedly rational nature of buyer decisionmaking because it is buyers that drive the economic model of form contracts, not because of any assumption or belief that sellers are not also boundedly rational decisionmakers. 
For buyers to enforce such effective market discipline on sellers, their comparative analysis of product choices must be both nonselective and compensatory. Non-selective decisionmaking requires that the buyer compare all attributes of each available product before deciding which he prefers. ${ }^{54}$ Not only, for example, does the buyer have to compare a red car to one with a stereo; he must compare a red car with a sun roof, a generous financing provision, and a warranty disclaimer, to a blue car with an advanced technology steering system, anti-lock brakes, no financing, and an arbitration clause. In a competitive market for an even moderately complex product, a truly nonselective approach could require the decisionmaker to compare a large number of alternatives on an even larger number of attributes.

Compensatory analysis requires the decisionmaker to trade off the desirable attributes of one product against the desirable attributes of a competing product." If an automobile buyer values a red car and a stereo, and one available car is red but has no stereo while another has a stereo but is not red, he must be able to determine which of the two cars is more desirable. If the buyer values both a low price and the ability to take the manufacturer to court should a dispute arise under the contract, and one car comes with a mandatory arbitration provision while another has no such provision and is $\$ 100$ more expensive, he must be able to determine whether he prefers the extra $\$ 100$ in his pocket to keeping the courthouse door open.

Fully non-selective and compensatory decisionmaking, as it turns out, is quite difficult to execute. To make decisions that satisfy these requirements, a decisionmaker must employ something similar to what decision theorists call the "weighted-adding" strategy. ${ }^{56}$ To employ this strategy, the decisionmaker assigns an importance weight to each different attribute that defines the product in question: Very important attributes are awarded large weights; less important attributes are given smaller weights. He then assigns each alternative product a quality score on each attribute, with an alternative receiving a high score if it is highly desirable as concerns that attribute. By then multiplying the attribute weight by the attribute score for each alternative and then summing the products, each alternative can be assigned a single numerical score representing its relative utility to the decision-

\$4 See, for example, Bettman, Luce, and Payne, $25 \mathrm{~J}$ Consumer Rsrch at 189 (cited in note 51 ).

55 See id at 190; John W. Payne, James R. Bettman, and Eric J. Johnson, The Adaptive Decision Maker 29 (Cambridge 1993).

56 See Bettman, Luce, and Payne, 25 J Consumer Rsrch at 190 (cited in note 51); Payne, Bettman, and Johnson, The Adaptive Decision Maker at 24 (cited in note 55). 
maker. ${ }^{57}$ A buyer using this strategy then selects the product with the highest score, thus maximizing his utility given the available options.

To see how weighted adding is accomplished, consider a relatively simple hypothetical choice between three product alternatives, each of which has six different attributes of varying importance, as provided in Figure 1 below. In this example, the weighted-adding approach, which gives each attribute its appropriate weight and compares all three alternatives on each attribute, tells us that the decisionmaker will maximize his expected utility by selecting Alternative C. Although Alternative $\mathrm{C}$ is the least attractive of the choices on the most important attribute, it is so much more attractive than the other alternatives on attributes 3-6 that it is the optimal choice overall.

\section{Figure 1}

\begin{tabular}{|l|l|l|l|l|l|l|l|}
\hline \multicolumn{2}{|l|}{ Alternative } & \multicolumn{2}{l|}{ A } & \multicolumn{2}{l|}{ B } & \multicolumn{2}{l|}{} \\
\hline Attribute & Weight & Score & $\begin{array}{l}\text { Score } \mathrm{x} \\
\text { Weight }\end{array}$ & Score & $\begin{array}{l}\text { Score x } \\
\text { Weight }\end{array}$ & Score & $\begin{array}{l}\text { Score } \mathrm{x} \\
\text { Weight }\end{array}$ \\
\hline 1 & $30 \%$ & 100 & 30 & 90 & 27 & 10 & 3 \\
\hline 2 & $25 \%$ & 40 & 10 & 80 & 20 & 60 & 15 \\
\hline 3 & $20 \%$ & 10 & 2 & 20 & 4 & 100 & 20 \\
\hline 4 & $10 \%$ & 10 & 1 & 30 & 3 & 100 & 10 \\
\hline 5 & $10 \%$ & 30 & 3 & 30 & 3 & 100 & 10 \\
\hline 6 & $5 \%$ & 20 & 1 & 20 & 1 & 100 & 5 \\
\hline \multicolumn{2}{|l|}{ Total Score } & & $\mathbf{4 7}$ & & $\mathbf{5 8}$ & & $\mathbf{6 3}$ \\
\hline
\end{tabular}

When buyers use the weighted-adding strategy - or any similar approach that also compares each alternative on each attribute ${ }^{59}-$ to

57 Bettman, Luce, and Payne, 25 J Consumer Rsrch at 190 (cited in note 51).

58 This is not quite accurate. The weighted-adding approach, as described here and in Figure 1 , is not guaranteed to maximize the buyer's expected utility because it implicitly assumes that the utility provided by each attribute is independent of other attributes. In reality, the utility created by an attribute of a particular product will often depend on what other attributes that product has. Thus, to guarantee that the buyer's product choice would maximize his expected utility, his decisionmaking process would have to be even more complex than the one described here. See Robin M. Hogarth, Judgement and Choice: The Psychology of Decision 73-74 (Wiley 2d ed 1987).

59 "Weighted adding" is also called the "linear compensatory" model. See, for example, id at 73-75; J. Kevin Ford, et al, Process Tracing Methods: Contributions, Problems, and Neglected Research Questions, 43 Org Beh \& Human Dec Processes 75, 77 (1989). The "additive difference" strategy is applied slightly differently as a matter of procedure but leads to the same result. See, for example, Hogarth, Judgement and Choice at 75 (cited in note 58). These approaches are forms of what is commonly known as multi-attribute utility analysis, see, for example, Ralph $\mathrm{L}$. Keeney and Howard Raiffa, Decisions with Multiple Objectives: Preferences and Value Tradeoffs 282-353 (Wiley 1976), although the weighted-adding approach assumes that the value of each 
evaluate competing products in a competitive market, market pressures will force sellers to provide efficient form contract terms (as well as other product features). This, in turn, suggests that courts will make buyers as a class, as well as society as a whole, better off by enforcing those terms rather than substituting alternative terms. But decision theorists consider the weighted-adding strategy to be a normative rather than a positive approach to decisionmaking in most circumstances." That is, it will lead to the optimal choice given the decisionmaker's preferences," but it is not how decisionmakers-even those who are "shoppers" - actually go about making purchasing choices."

\section{B. Boundedly Rational Decisionmaking}

One way to think about fully compensatory and non-selective approaches to choice, such as weighted adding, is that they maximize the accuracy of choice-defined as the fit between the product selected and the preferences of the chooser. As the description of the weighted-adding strategy and the accompanying example suggest, however, maximizing accuracy is no easy task: It requires expending a large amount of effort, in terms of both time and mental attention.

The problem that buyers face of choosing among product alternatives thus can be reframed as a problem of balancing the desire to make accurate choices with the mutually exclusive desire to minimize effort. $^{\text {th }}$ On one end of the spectrum of strategies lies weighted adding, which yields very high accuracy but requires a very high degree of effort." On the other end of the spectrum lies "random choice"perhaps selecting a product by throwing darts at a list of the available alternatives. $^{\text {66 }}$ Random choice requires little effort. It is neither compensatory nor non-selective: The decisionmaker need not consider all the available information about product alternatives or compare different types of attributes to one another. But random choice also

choice attribute is independent, whereas multi-attribute utility analysis need not necessarily have this feature.

6) See Bettman, Luce, and Payne, $25 \mathrm{~J}$ Consumer Rsrch at 195 (cited in note 51); Raanan Lipshitz, et al, Focus Article: Taking Stock of Naturalistic Decision Making, $14 \mathrm{~J}$ Beh Dec Making 331,333 (2001).

61 See Bettman, Luce, and Payne, $25 \mathrm{~J}$ Consumer Rsrch at 190 (cited in note 51).

62 See, for example, Hogarth, Judgement and Choice at 74 (cited in note 58) ("[A]s a description of choice processes, the linear model is often inadequate."); Hillman and Rachlinski, 77 NYU L Rev at 451 (cited in note 2) ("[P]sychologists long have believed that when making a decision, such as whether to enter into a contract, people rarely invest in a complete search for information, nor do they fully process the information they receive.").

63 See Bettman, Luce, and Payne. 25 J Consumer Rsrch at 195 (cited in note 51).

64 Id at 192. See also Payne, Bettman, and Johnson, The Adaptive Decision Maker at 11 (cited in note 55).

65 See Figure 2.

6h Id. 
promises little accuracy, in that it is unlikely to result in a buyer purchasing the product that maximizes his utility.

\section{Figure 2}

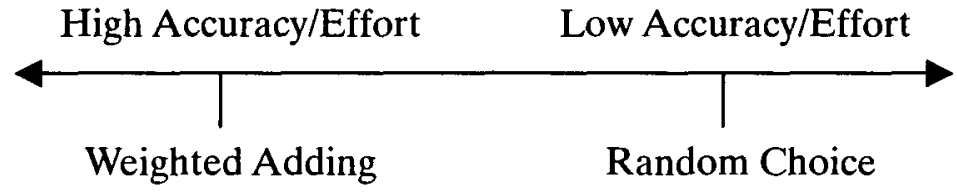

While most buyers employ decision strategies that require more effort than the random choice approach, they rarely use strategies as accurate as weighted adding. Like other individuals, they usually solve problems using heuristics, or mental short-cuts, that provide solutions with less than maximum effort, as opposed to algorithms, which require patient and often lengthy calculation." Decision theorists have proposed numerous descriptive models of choice that fall between weighted adding and random choice on the accuracy/effort spectrum, all of which are simpler than weighted adding but more complex than random choice. A brief review of a few of these is useful to illustrate how all choice strategies that are less accurate than weighted adding are either selective, non-compensatory, or both.

The lexicographic strategy calls for the decisionmaker to select the product alternative with the highest score on the most important attribute. ${ }^{67}$ For example, if "body style" is the most important attribute to a car buyer, the buyer will purchase the car with the most pleasing styling, regardless of how that car ranks on other design attributes, price, or contract terms. In the example provided in Figure 1, the decisionmaker using the lexicographic approach would select Alternative $A$, because it is the most desirable alternative on Attribute 1, the most important attribute. This approach is both selective, in that it requires the chooser to examine only a single attribute across product alternatives, and non-compensatory, in that different features do not have to be compared to each other. For buyers, the approach requires relatively little effort and promises relatively little accuracy, at least as compared to other plausible strategies. As the example in Figure 1 indicates, Alternative $A$ actually will provide the least amount of ex-

67 See C. Mantzavinos, Individuals, Institutions, and Markets 36 (Cambridge 2001) ("Heuristics are to be understood as general strategies that provide quick solutions with little effort .... Heuristics are to be contrasted to 'algorithms,' methodical procedures that guarantee success by solving problems through their lengthy, patient application.").

68 See Bettman, Luce, and Payne, 25 J Consumer Rsrch at 190 (cited in note 51); Wright, 12 J Marketing Rsrch at 61 (cited in note 51). 
pected utility for the decisionmaker, since it earns the lowest total score under the weighted-average strategy.

Herbert Simon long ago hypothesized that, rather than optimizing, decisionmakers define a minimum aspiration level and opt for the first alternative that reaches it. ${ }^{\text {. }}$ A number of decisionmaking models attempt to operationalize Simon's insight. The conjunctive strategy assumes that the decisionmaker will select an alternative that exceeds a minimum acceptable level on all attributes, without regard to whether it exceeds those thresholds by a small or large amount. ${ }^{70}$ This approach is non-selective, because all attributes are considered, but noncompensatory, because a high score on one attribute is not compared to a high score on a different attribute. In the hypothetical described in Figure 1, assuming that the minimum acceptable value for each attribute is twenty, only Alternative B could be selected.

Using an elimination-by-aspects strategy - a variation of the conjunctive strategy - the decisionmaker examines all product alternatives on the attribute most important to him and eliminates from consideration any alternatives for which that attribute does not meet a minimum acceptable level. ${ }^{71}$ If multiple alternatives remain under consideration, the decisionmaker goes on to the next most important attribute and eliminates from consideration all alternatives that fail to score satisfactorily on that attribute, and so on. When all products but one have been eliminated by this procedure, the decisionmaker selects the one that remains. Elimination by aspects is non-compensatory, like the conjunctive approach, but also selective because not all of the relevant data will be considered.

Again consider the hypothetical described in Figure 1, and assume that a score of twenty represents the minimum acceptable quality of each attribute to the decisionmaker. A decisionmaker employing the elimination-by-aspects strategy first would compare each alternative on Attribute 1, eliminating from consideration Alternative $C$, which has a score below twenty on that attribute. She would then consider the value of the remaining Alternatives, $\mathrm{A}$ and $\mathrm{B}$, according to

69 See Herbert A. Simon, A Behavioral Model of Rational Choice, 69 Q J Econ 99, $104-05$ (1955); Herbert A. Simon, Rational Choice and the Structure of the Environment, 63 Psych Rev 129 (1956). See also James G. March and Herbert A. Simon, Organizations 140-41 (Wiley 1958) ("Most human decision-making ... is concerned with the discovery and selection of satisfactory alternatives; only in exceptional cases is it concerned with the discovery and selection of optimal alternatives.") (emphasis omitted).

70 See John W. Payne, Task Complexity and Contingent Processing in Decision Making: An Information Search and Protocol Analysis, 16 Org Beh \& Human Performance 366, 367 (1976).

71 The term "elimination by aspects" was coined in Amos Tversky's Elimination by Aspects: A Theory of Choice, 79 Psych Rev 281 (1972). The precise contours of the approach have been altered slightly by different theorists. See, for example, Bettman, Luce, and Payne, $25 \mathrm{~J}$ Consumer Rsrch at 190 (cited in note 51 ). 
their scores on the second most important attribute. Because the score of Alternative $\mathrm{A}$ is below the threshold of twenty points, that option would be eliminated, and Alternative B again would be selected, although on the basis of less information than would be required for the conjunctive model.

The structured choice strategies described above are highly stylized and probably used infrequently in their pure form by many buyers. The leading descriptive work on decision strategies concludes that decisionmakers are more likely to combine elements from many different choice strategies than to adopt a single one in its entirety. ${ }^{72}$ The important insights, for purposes of this Article, are that (1) in many circumstances, decisionmakers use selective and/or non-compensatory decision strategies that are thus inconsistent with the decision strategies assumed in the standard economic approach to the analysis of form contract terms; and (2) if buyers rely on decisionmaking strategies that are simpler than weighted adding, some information is ignored that must be considered if market incentives are to force sellers to offer only efficient product attributes.

For any given buyer, I refer to product attributes that are evaluated, compared, and implicitly priced as part of the purchase decision as "salient" attributes and product attributes that are not evaluated, compared, and priced as part of the purchase decision as "non-salient" attributes. As section D explains, this distinction is of crucial importance, because market pressures should insure that salient form terms are efficient, whereas there is no reason to assume that non-salient terms will be efficient.

\section{Salience and Form Contract Terms}

One of the principal findings of decision research is that decisionmaking behavior is highly contingent on context, ${ }^{73}$ which makes it impossible to identify a single, specific strategy that buyers will use when making purchasing choices in the marketplace or a precise list of which attributes will be salient to them and which will be non-salient. Decision research does provide a basis, however, for predicting that terms found in form contracts frequently will be nonsalient to most buyers. This prediction relies on two factual premises. First, purchase decisions involving products with form contracts are sufficiently complex that buyers usually will be selective in their con-

72 Payne, Bettman, and Johnson, The Adaptive Decision Maker at 28-29 (cited in note 55).

73 See, for example, John W. Payne, Contingent Decision Behavior, 92 Psych Bull 382 (1982) (reviewing research); Johnson and Meyer, $11 \mathrm{~J}$ Consumer Rsrch at 529 (cited in note 51) (noting as an example that people use comparisons of attributes when faced with a choice between two alternatives, but use elimination strategies when faced with many alternatives). 
sideration of product attributes. That is, at least some attributes will be non-salient. Second, relative to other product attributes, form terms are particularly likely to be non-salient because their usual content makes them unlikely to attract buyers' voluntary or involuntary attention. This section defends these two premises.

\section{Complexity and selectivity.}

As the amount of relevant information increases, decisions increase in complexity and demand higher levels of cognitive effort. ${ }^{74}$ Because individuals' selection of choice strategies can be viewed as balancing the desire to achieve accuracy with the desire to minimize effort, it follows logically that as decisions become more complex, decisionmakers will tend to adopt simpler choice strategies to cope with that complexity. ${ }^{75}$ The research of decision theorists confirms this reasoning, ${ }^{76}$ suggesting that increased information load causes increased selectivity in the information processed."

74 See Payne, Bettman, and Johnson, The Adaptive Decision Maker at 85-86 (cited in note 55) (finding that experimental subjects evaluated more complex decisions as requiring more effort).

75 See, for example, Ford, et al, 43 Org Beh \& Human Dec Processes at 105 (cited in note 59) (calling the "most robust finding[]" of their review of studies that "as the number of dimensions and alternatives increase, there is a greater likelihood that the decision maker will use nonlinear strategies," and noting that this conclusion has been found with different types of subjects, different choice tasks, and different research protocols); Richard W. Olshavsky, Task Complexity and Contingent Processing in Decision Making: A Replication and Extension, 24 Org Beh \& Human Performance 300, 300 (1979).

76 See, for example, Sheena S. Iyengar and Mark R. Lepper, When Choice Is Demotivating: Can One Desire Too Much of a Good Thing?, 79 J Personality \& Soc Psych 995, 999 (2000) ("[W]hen people have 'too many' options to consider, they simply strive to end the choicemaking ordeal by finding a choice that is merely satisfactory, rather than optimal."); Ellen C. Garbarino and Julie A. Edell, Cognitive Effort, Affect, and Choice, 24 J Consumer Rsrch 147, 148 (1997) ("As environments require more cognitive effort to process information fully, decision makers often switch to decision strategies or heuristics that are easier to implement .... [P]eople are willing to forgo some benefits to conserve cognitive effort."); Barbara E. Kahn and Jonathan Baron, An Exploratory Study of Choice Rules Favored for High-Stakes Decisions, 4 J Consumer Psych 305, 306-07 (1995) (commenting that as decisions increase in complexity, observed decision strategies deviate from the normative strategy); Payne, Bettman, and Johnson, The Adaptive Decision Maker at 34 (cited in note 55) ("[A]s decisions become more complex, people will tend to use simplifying decision heuristics."); Naresh K. Malhotra, Information Load and Consumer Decision Making, 8 J Consumer Rsrch 419, 427 (1982); James R. Bettman, An Information Processing Theory of Consumer Choice 221 (Addison-Wesley 1979); Peter Wright, 12 J Marketing Rsrch at 62 (cited in note 51).

77 See Bettman, Luce, and Payne, 25 J Consumer Rsrch at 200 (cited in note 51) ("[W]e believe that the essence of consumer response to information load is selectivity."); Ford, et al, 43 Org Beh \& Human Dec Processes at 99 (cited in note 59) (reviewing forty-five studies and concluding that " $[\mathrm{t}]$ he results indicate that increasing task complexity (increasing the number of alternatives, dimensions, or both alternatives and dimensions) increases the likelihood that subjects use simplifying nonlinear strategies to make their decision task more manageable") (citations omitted). 
Two obvious sources of complexity that can cause buyers to adopt simpler decision strategies are the number of alternatives available, and the number of relevant attributes for each alternative. ${ }^{78} \mathrm{Al}$ though the evidence is robust that the presence of a large number of alternatives causes decisionmakers to employ relatively simple decisionmaking strategies," this finding will not be emphasized here for two reasons. First, when choosing between product options, buyers might or might not face a large number of alternatives, depending on the particular market and whether they are "shoppers" or "nonshoppers." Second, when buyers face a large number of alternatives initially, they often use one decisionmaking strategy to pare down the number of alternatives to a more manageable number and then switch strategies when making their choice among the reduced set of options. ${ }^{\text {*I }}$ For both reasons, the evidence of how buyers act in the face of large numbers of options may not have universal application to the context of buyers making a final purchasing decision.

More important for the analysis of form contracts is the empirical research that suggests the number of attributes decisionmakers are likely even to investigate - much less actually price as part of the decisionmaking procedure - when choosing between alternatives is surprisingly modest by contemporary product standards, ${ }^{81}$ perhaps as few as five $e^{12}$ (although this number can certainly vary depending on the individual, ${ }^{83}$ the importance of the choice, and the time allotted to make

78 See, for example, Barry Schwartz, Self-Determination: The Tyranny of Freedom, 55 Am Psychologist 79,86 (2000) ("It is hard enough to ... go through the deliberations needed to make the best choice among six options. To choose the best among 30 options is truly daunting.").

79 See, for example, Johnson and Meyer, $11 \mathrm{~J}$ Consumer Rsrch at 539 (cited in note 51) (finding that larger numbers of alternatives increases the likelihood of subjects using "elimination" decision strategies); Clyde Hendrick, Judson Mills, and Charles A. Kiesler, Decision Time as a Function of the Number and Complexity of Equally Attractive Alternatives, $8 \mathrm{~J}$ Personality \& Soc Psych 313, 317 (1968) (finding subjects spent less time choosing between four alternatives than two alternatives, which suggests the use of simpler decision strategies).

80 See, for example, Grether, Schwartz, and Wilde, 59 S Cal L Rev at 281-82 (cited in note 48); James R. Bettman and C. Whan Park, Effects of Prior Knowledge and Experience and Phase of the Choice Process on Consumer Decision Processes: A Protocol Analysis, $7 \mathrm{~J}$ Consumer Rsrch 234,244 (1980) (finding subjects switched from non-compensatory to compensatory strategies when alternatives were eliminated).

81 See Payne, Bettman, and Johnson, The Adaptive Decision Maker at 36 (cited in note 55); Bettman, Luce, and Payne, $25 \mathrm{~J}$ Consumer Rsrch at 199 (cited in note 51) (noting that an increased number of attributes may lead to increased selectivity).

82 See Denis A. Lussier and Richard W. Olshavsky, Task Complexity and Contingent Processing in Brand Choice, $6 \mathrm{~J}$ Consumer Rsrch 154, 155 (1979) ("Judging from past research, three brands and five attributes [are] approximately what consumers really consider[]."). See also Grether, Schwartz, and Wilde, $59 \mathrm{~S} \mathrm{Cal} \mathrm{L} \mathrm{Rev} \mathrm{at} 300$ (cited in note 48) (concluding from a number of studies that "the number of salient or determinant product attributes ... does not exceed five, and often is less").

83 See, for example, Olshavsky, 24 Org Beh \& Human Performance at 314 (cited in note 75) (finding considerable variation of choice strategies among subjects in a decisionmaking experiment); James Onken, Reid Hastie, and William Revelle, Individual Differences in the Use of 
the decision $\left.{ }^{\mathrm{k} 4}\right)$. In one experiment, researchers found that subjects asked to choose among alternative brands of typewriters, each of which with multiple attributes, tended to employ a two-step decision process. First, the subjects used a selective and non-compensatory approach to reduce the number of brands under consideration to a maximum of three or four. ${ }^{87}$ Second, they conducted a compensatory analysis of the remaining brands that selectively included only five or fewer attributes, even when information on more attributes was available."

In another experiment, subjects exposed to information about either six or fifteen product attributes of condominium units or stereos were asked to select one of several alternatives, reasoning through their choice process verbally. ${ }^{\mathrm{k} 9}$ In the fifteen-attribute condition, the experimenters concluded that "nearly all subjects" ignored certain product attributes in their decisionmaking process." Subjects in another experiment were asked to choose from among two or more alternative apartments, each of which was rated on four, eight, or twelve attributes." Faced with only two alternatives of four attributes each, the subjects consulted all of the available information before making a choice. ${ }^{2}$ Even with only two alternatives, some subjects facing eight or twelve attributes did not consult (much less make use of) all of the attribute information prior to choosing. ${ }^{93}$ With more alternatives, subjects consulted even less information. ${ }^{94}$ Yet another study found that the number of attributes per alternative considered by decisionmakers

Simplification Strategies in a Complex Decision-Making Task, $11 \mathrm{~J}$ Exp Psych: Human Perception \& Performance 14 (1985) (postulating that decision strategy selection is influenced by individual differences in speed and reliability of memory and speed with which processing operations are performed).

84 As time allotted to make decisions becomes more condensed, decisionmakers at first become more selective in the information they consider and then adopt non-compensatory decisionmaking strategies. See Bettman, Luce, and Payne, $25 \mathrm{~J}$ Consumer Rsrch at 200 (cited in note 51).

85 As a sign of how much technology has changed in the two decades since this study was published, the experimenters selected typewriters as the product for the experiment because of their "high degree of relevance to student[] [subjects]. In a pretest, it was found that approximately 70 percent of the students use a typewriter." Lussier and Olshavsky, $6 \mathrm{~J}$ Consumer Rsrch at 155 (cited in note 82).

86 Id at 160 .

87 Id at $160-62$.

88 Id at 162.

89 Olshavsky, 24 Org Beh \& Human Performance at 305 (cited in note 75).

90 Id at 311.

91 Payne, 16 Org Beh \& Human Performance at 374 table 2 (cited in note 70 ).

92 Id.

93 Id. Interestingly, all subjects with two alternatives appeared to use compensatory (although not always non-selective) choice processes, whereas subjects facing more than two alternatives tended to use non-compensatory strategies. Id at 373-74.

94 Id at 374. 
ranged only from 3.0 to $6.6 .{ }^{9.5}$ Even expert decisionmakers, it seems, are similarly selective in the amount of information consulted when making decisions."

In one particularly revealing study, experimenters first interviewed subjects, collecting information about their preferences concerning a variety of features of houses. ${ }^{97}$ They then asked the subjects to select their preferred house from five alternative choices. Subjects' ability to choose the alternative that would maximize their utility (based on the information they provided in the earlier interviews) was constant when descriptions contained between five and ten attributes for each alternative. But when the experimenters increased the number of attributes described to fifteen or more, the subjects made fewer accurate choices, ${ }^{\text {g8 }}$ thus suggesting that subjects employed simpler decision strategies when the number of attributes became large.

Faced with extremely simple choices defined by few attributes, individuals probably can be counted on, generally, to engage in nonselective and compensatory processing that will result in utility maximization. ${ }^{\text {wo }}$ Nearly all products and services provided by the modern economy that are accompanied by form contracts, however, are characterized by a relatively large number of attributes concerning functionality, aesthetics, cost, and terms. Because buyers routinely take account of only a handful of attributes, whenever buyers make purchase decisions where form contracts are involved, a number of product attributes will usually be non-salient. ${ }^{100}$

\section{Salience and attention.}

Psychological research divides the concept of attention into two categories: voluntary and involuntary. ${ }^{101}$ In other words, people pay attention to environmental stimuli either because we voluntarily choose

95 Danielle Timmermans, The Impact of Task Complexity on Information Use in Multiattribute Decision Making, 6 J Beh Dec Making 95, 100 exhibit 1 (1993).

96 See, for example, Ruth H. Phelps and James Shanteau, Livestock Judges: How Much Information Can an Expert Use?, 21 Org Beh \& Human Performance 209, 209-10 (1978).

97 See Malhotra, $8 \mathrm{~J}$ Consumer Rsrch at 421 (cited in note 76).

98 Id at 422-23 table 1.

99 See Kahn and Baron, $4 \mathrm{~J}$ Consumer Psych at 306, 314 (cited in note 76) (citing studies showing that subjects' choices approach normative outcomes when problems are very simple).

100 Grether, Schwartz, and Wilde argue that (1) decision research experiments demonstrate that "when choice sets are small or otherwise not complex, people are good at making decisions that are in their own best interests," and (2) "the best inference from the evidence is that consumers do not experience serious problems as a result of the amount of information that the markets and the state now generate." 59 S Cal L Rev at 294 (cited in note 48). The first of their claims-based on research - is defensible; the second of their claims - the inference that they draw from the research - seems impossible to defend, at least for any product complex enough to be accompanied by form contract terms.

101 See Bettman, Luce, and Payne, 25 J Consumer Rsrch at 193 (cited in note 51). 
to do so, or because aspects of the environment are intrinsically noticeable and capture our attention involuntarily: For a product attribute to be salient to buyers, the attribute must capture the limited attention of those buyers. But the nature of form contract terms suggests that they often will not be the focus of voluntary attention or capable of capturing attention involuntarily.

Individuals devote voluntary attention to information when doing so will help them to obtain their goals. Because buyers usually will wish to maximize the accuracy of their purchase decisions given a fixed amount of effort expended, buyers who focus attention on a limited number of product attributes can be expected to attempt to focus that attention on the attributes that are most important to them. Experience suggests that the terms found in form contracts often, although not always, will be less important to buyers than other attributes such as price, functionality, and physical appearance, and thus will be a less likely focus of attention.

Somewhat more speculatively, the nature of certain types of terms prevalent in form contracts also suggests that buyers might often choose to focus their attention elsewhere, but for a very different reason. Research suggests that individuals experience conflict when forced to compare dissimilar attributes to each other, ${ }^{112}$ that is, compensatory decisionmaking is emotionally difficult. ${ }^{113}$ This general problem is perhaps most acute, however, when comparing dissimilar attributes would require the decisionmaker to put an implicit price on attributes that she intuitively feels should not be commodified ${ }^{114}$ or trade off attributes that she feels should not be sacrificed. ${ }^{105}$ For example, a decisionmaker is likely to face more stress when forced to make a tradeoff between lives saved and dollars spent on highway maintenance than between the size of an apartment and the dollars spent on

102 See Dhar, $24 \mathrm{~J}$ Consumer Rsrch at 217 (cited in note 51) (reviewing literature). See generally Amos Tversky and Eldar Shafir, Choice under Conflict: The Dynamics of Deferred Decision, 3 Psych Sci 358 (1992); Roger N. Shepard, On Subjectively Optimum Selection among Multiattribute Alternatives, in M.W. Shelly and G.L. Bryan, eds, Human Judgments and Optimality 257 (Wiley 1964).

103 See Hogarth, Judgement and Choice at 77 (cited in note 58).

104 See Mark Kelman, Consumption Theory, Production Theory, and Ideology in the Coase Theorem, 52 S Cal L Rev 669, 692 (1979) (observing that people avoid placing some goods in "the realm of marginalism and calculation").

105 Bettman, Luce, and Payne, $25 \mathrm{~J}$ Consumer Rsrch at 196 (cited in note 51). See generally Jonathan Baron and Mark Spranca, Protected Values, 70 Org Beh \& Human Dec Processes 1, 4 (1997). 
rent. ${ }^{106}$ Decision researchers have labeled choices that require particularly uncomfortable tradeoffs as "emotion laden."

A plausible inference drawn from this research is that two typical types of contract terms, usually found buried in the text of standard forms, are likely to cause elevated stress levels for buyers. The first type places limitations on the ability of buyers to recover damages for personal injuries caused by the product, such as liability waivers and exclusions of consequential damages. The second type causes buyers to waive traditional means of legal redress, such as mandatory arbitration provisions and forum selection clauses. If buyers believe that personal safety or the right to seek redress of legal wrongs in a court of law are entitlements that should be inalienable and not subject to commodification, explicitly trading off these types of entitlements against a product's price and physical features might create elevated stress levels.

Research further suggests that decisionmakers often respond to the presence of emotion-laden choices by adopting non-compensatory choice strategies, which alleviate the burden of making explicit tradeoffs between attributes that are stressful to compare. ${ }^{118}$ For example, a car buyer might adopt a strategy of purchasing the cheapest car or, alternatively, purchasing only a car with air bags and anti-lock brakes no matter what the cost, in order to avoid the emotionally stressful task of "putting a price on safety." Buyers are likely to respond to the stress caused by sellers' attempts to force them to commodify personal safety or legal rights by employing non-compensatory decisionmaking strategies that allow them to avoid making such tradeoffs-by

106 The example is from Jane Beattie and Jonathan Baron, Investigating the Effect of Stimulus Range on Attribute Weight, 17 J Exp Psych: Human Perception \& Performance 571, 571 (1991).

107 See Bettman, Luce, and Payne, 25 J Consumer Rsrch at 196-97 (cited in note 51).

108 See Mary Frances Luce, James R. Bettman, and John W. Payne, Choice Processing in Emotionally Difficult Decisions, 23 J Exp Psych: Learning, Memory, \& Cognition 384, 402 (1997). See also Bettman, Luce, and Payne, $25 \mathrm{~J}$ Consumer Rsrch at 197 (cited in note 51); Payne, Bettman, and Johnson, The Adaptive Decision Maker at 30 (cited in note 55); Baron and Spranca, 70 Org Beh \& Human Dec Processes at 4-5 (cited in note 105). Another apparent consequence of choices with a high emotional content is that individuals are likely to spend more time and examine more information before making a decision. Luce, Bettman, and Payne, $23 \mathrm{~J}$ Exp Psych: Learning, Memory, \& Cognition at 401. The apparent contradiction between this finding and the finding that emotion-laden choices lead to more non-compensatory decisionmaking strategies can be reconciled by realizing that negative emotion provides an incentive to decisionmakers to make accurate choices, and therefore to work hard at making the decision, but to simultaneously seek to minimize the conflict causing the negative emotion, and therefore adopt a decisionmaking strategy that is not particularly accurate. Id at 401-02 (speculating that as task-related emotion increases, decision accuracy will decrease).

109 See Beattie and Baron, 17 J Exp Psych: Human Perception \& Performance at 571 (cited in note 106). 
effectively ignoring these terms during the selection process and thus rendering them non-salient.

Another reason that form terms seem unlikely to garner attention stems from the fact that many such terms govern eventualities that are extremely unlikely to occur. One of the most robust findings of social science research on judgment and decisionmaking is that individuals are quite bad at taking into account probability estimates when making decisions." ${ }^{111}$ For low-probability risks, individuals often either overweigh the possibility of harm, taking excessive precaution relative to the actual risk, or ignore the risk altogether. This is a consequence of translating probabalistic risks into judgments that situations are either "safe" or "unsafe." For example, one study shows that people are willing to pay either virtually nothing to insure against a risk or else pay far more than the risk's expected cost. ${ }^{112}$

One explanation for why individuals might treat certain lowprobability risks as if they were virtually non-existent is that they are excessively confident in their likelihood of avoiding harm. ${ }^{113}$ Such overconfidence cannot be the complete story, however, since there is strong evidence that individuals also exaggerate low-probability risks in some circumstances. ${ }^{114}$ A more likely explanation for the phenomenon is that, naturally poor at conducting implicit probability calculations, people often assess risk via the "availability heuristic,"11

110 This is often referred to as the "heuristics and biases" research. See generally Jeffrey J. Rachlinski, The Uncertain Psychological Case for Paternalism, 97 Nw U L Rev 1165, 1170-73 (2003) (reviewing social science research). It is based on the pioneering research of Amos Tversky and Daniel Kahneman and their successors. See, for example, Amos Tversky and Daniel Kahneman, Judgment under Uncertainty: Heuristics and Biases, 185 Sci 1124 (1974). Others have argued that, in real world situations, individuals are not as bad at making decisions concerning probabilities as some laboratory experiments suggest. See Gerd Gigerenzer, Peter M. Todd, and the ABC Research Group, Simple Heuristics That Make Us Smart (Oxford 1999).

111 See Cass R. Sunstein, Probability Neglect: Emotions, Worst Cases, and Law, 112 Yale L J 61,74 (2002).

112 Gary H. McClelland, William D. Schulze, and Don L. Coursey, Insurance for LowProbability Hazards: A Bimodal Response to Unlikely Events, 7 J Risk \& Uncertainty 95 (1993).

113 See, for example, Neil D. Weinstein, Unrealistic Optimism about Future Life Events, $39 \mathrm{~J}$ Personality \& Soc Psych 806 (1980) (demonstrating overconfidence in predictions about the likelihood of subjects experiencing positive and negative events); Lynn A. Baker and Robert E. Emery, When Every Relationship Is Above Average: Perceptions and Expectations of Divorce at the Time of Marriage, $17 \mathrm{~L} \&$ Human Beh 439, 443 (1993) (noting that the modal subject said his probability of getting divorced was 0 percent).

114 See, for example, Jon D. Hansen and Douglas A. Kysar, Taking Behavioralism Seriously: The Problem of Market Manipulation, 74 NYU L Rev 630,693-721 (1999) (reviewing literature demonstrating that individuals both underestimate and overestimate the risk of injury from defective products).

115 See generally Amos Tversky and Daniel Kahneman, Judgment under Uncertainty: Heuristics and Biases, in Daniel Kahneman, Paul Slovic, and Amos Tversky, eds, Judgment under Uncertainty: Heuristics and Biases 3, 11-14 (Cambridge 1982). 
judging risk to be high when the type of harm is familiar or easily imagined and low when it is not."

Many of the terms commonly specified in standard form contracts govern what will happen if a low-probability risk comes to pass: if the seller's product does not function; if the buyer does not pay on time; if the parties become embroiled in a dispute that leads to litigation; if the buyer is injured; etc. If these possible but unlikely outcomes are not readily "available" to buyers, they are likely to respond to the risk of these harms by treating them as if they do not exist at all."17 If buyers are disposed to substantially discount the risks implied by form contract terms, buyers operating in a content-rich environment in which they must consider information only selectively might allocate their attention elsewhere, rendering the form terms that concern low-probability risks non-salient.

If buyers are not likely to focus their limited attention in complex decision environments on form contract terms voluntarily, those terms are also unlikely to capture buyers' attention involuntarily. The way in which sellers display information affects the attention paid to it ${ }^{110}$ and thus the likelihood of its being salient in the decision process. Form terms are usually displayed in ways that make them hard to read, hard to understand, and hard to compare to the terms accompanying competing products, ${ }^{119}$ thus making them particularly unlikely to be salient product attributes to buyers.

If buyers adopt selective choice strategies that make use of only some product attributes and form terms are rarely among these attributes, it is not difficult to explain the common observation that buyers rarely read the terms in form contracts. ${ }^{121}$ It is not simply the fact that reading the terms (and sometimes understanding them) is time-consuming, as many commentators point out, ${ }^{121}$ although it is no

116 See Sunstein, 112 Yale L J at 70 (cited in note 111) ("When it comes to risk, a key question is whether people can imagine or visualize the worst-case outcome."). See also Hogarth, Judgement and Choice at 108 (cited in note 58) (claiming that overestimation of risk is likely when harms are "easy . . to imagine," such as nuclear power plant accidents and airplane crashes).

117 As one commentator put the point, "no one buying a cruise line ticket (save perhaps a lawyer) is thinking about his or her future slip-and-fall case. People expect disasters to happen to others." Paul D. Carrington, The Dark Side of Contract Law, 36 Trial 73, 76 (May 2000).

118 See J. Edward Russo, The Value of Unit Price Information, 14 J Marketing Rsrch 193, 194 (1977) (claiming that consumers make more accurate decisions when information is displayed in a convenient way); J. Edward Russo, et al, Nutritional Information in the Supermarket, 13 J Consumer Rsrch 48, 49-52 (1986) (same).

119 See Henningsen v Bloomfield Motors, Inc, 32 NJ 358, 161 A2d 69, 92 (1960) (asserting that a jury might find the seller's use of fine print was to "promote lack of attention rather than sharp scrutiny").

120) See note 46.

121 See, for example, Schwartz and Wilde, $127 \mathrm{U} \mathrm{Pa}$ L Rev at 660 (cited in note 23) ("Evaluating terms is more costly than evaluating prices or search characteristics such as color, size, or 
doubt true that in some cases the time investment required outweighs the benefits in terms of accuracy that can come from learning about the content of even salient attributes. ${ }^{122}$ More importantly, if a buyer is confident that the content of form terms will not be salient, there is no reason to read those terms, whether or not doing so will be difficult or time-consuming.

An important implication of this insight is that a non-salient term will not automatically become salient just because its content is communicated to the buyer. A form term calling for arbitration of disputes in an inconvenient state, for example, is likely to be non-salient to the vast majority of buyers unless the type of contract in question commonly results in disputes. This fact is not necessarily changed if the seller takes steps to inform the buyer about this term-for example, by orally informing the buyer or requiring him to write his initials next to the term on the contract to signal his actual knowledge and assent. "Notice" is a prerequisite of salience, but notice is not a sufficient condition of salience.

\section{The Link between Salience and Market Discipline}

The distinction between salient and non-salient product attributes is essential to the analysis of the efficiency of form contracts. Although market forces should ensure that sellers will offer efficient salient contract terms, non-salient attributes are subject to inefficiencies driven by the strategic behavior of sellers attempting to increase their profits at the expense of unknowing buyers. Far from operating as an invisible hand that promotes efficiency, market forces combined with the presence of non-salient product attributes can perversely enforce a regime of inefficiency. Assuming that the price of a product is a salient product attribute for buyers-surely a highly realistic assumption-market pressures will force sellers in competitive markets to offer low-quality non-salient contract terms, whether or not such terms are efficient. ${ }^{123}$ Except in the unlikely circumstance in which all efficient terms are low quality, then, there is reason to suspect that form contracts will contain some terms that reduce both the welfare of buyers and social welfare generally. The refusal by courts to enforce such terms would therefore increase social efficiency and buyer welfare. In a competitive market, such action would also increase sellers' welfare. The remainder of this Part explains these contentions.

fit.").

122 See Seita, 46 U Pitt L Rev at 134-35 (cited in note 9) (explaining the conditions in which a rational consumer should study contract terms).

123 Compare Jon D. Hanson and Douglas A. Kysar, Taking Behavioralism Seriously: Some Evidence of Market Manipulation, 112 Harv L Rev 1420, 1551 (1999) (arguing that market pressures will force sellers to manipulate consumers in order to remain competitive). 
1. Market pressure.

Assume, for the moment, that any particular product attribute is either salient to all buyers or non-salient to all buyers. Assume also that red widgets cost sellers $\$ 50$ more per unit to build than white widgets, but that buyers prefer red widgets and would be willing to pay $\$ 100$ more for a red widget than a white widget if forced to make that direct comparison. (Alternatively, the high-quality attribute could be a high-quality warranty and the low-quality attribute a limited warranty.) In this example, it is efficient for sellers to produce red widgets, and the market will provide them an incentive to do so, assuming that buyers price widget color as part of their purchase decisions. If color is not a salient attribute to buyers, however, sellers will have an incentive to sell only white widgets. Providing the inefficient color will not cause any customers to avoid the seller and buy elsewhere, but it will allow sellers to produce widgets more cheaply, boosting seller profits, at least in the short run before new competitors enter the market.

Now add one additional assumption: Although color is not a salient product attribute for buyers, price is a salient attribute. Given this realistic assumption, ${ }^{124}$ the incentives faced by sellers become even more pernicious. In a competitive market, sellers cannot remain in business if they produce red widgets. Because they consider price but not color, all buyers will purchase a white widget rather than a red widget, if the white widget is even slightly cheaper. Because sellers can reduce production costs by $\$ 50$ per unit by producing only white widgets, competition will drive the price of white widgets down $\$ 50$ (compared to the counterfactual price of red widgets). A producer of red widgets would be faced with a Hobson's choice: either (1) selling no widgets or (2) losing $\$ 50$ per unit sold. ${ }^{125}$ Economists will recognize this result as a type of "lemons" problem: When buyers cannot verify quality, the market will produce lower-quality goods. ${ }^{126}$ Ironically, far from guaranteeing a market equilibrium of efficient terms, competition can guarantee an equilibrium of inefficient terms.

This outcome is not only socially inefficient, it is undesirable for both buyers and sellers, as classes. In a competitive market, because buyers are offered only white widgets when red widgets could be pro-

124 See, for example, Hillman and Rachlinski, 77 NYU L Rev at 452 (cited in note 2) (hypothesizing that consumers will focus their attention on the "important' terms, such as price" while ignoring the boilerplate in contracts).

125 See Seita, 46 U Pitt L Rev at 145 (cited in note 9) (providing a similar explanation when consumers do not understand a contract term and the market is price competitive).

126 See generally George A. Akerlof, The Market for "Lemons": Quality Uncertainty and the Market Mechanism, 84 Q J Econ 488 (1970). See also Eisenberg, 47 Stan L Rev at 244 (cited in note 45) (arguing that competition can drive down the quality of pre-printed terms about which consumers are rationally ignorant). 
duced for less than their marginal value, buyers enjoy less consumer surplus than would be possible if sellers offered red widgets. Buyers who would be marginal purchasers of red widgets will not purchase white widgets, thus enjoying no consumer surplus rather than some. Sellers as a class will earn a market rate of return, but no more, whether they produce white or red widgets. But if sellers produce white widgets, fewer widgets will be sold, thus reducing sellers' total income.

\section{Heterogeneous but random salience.}

There is, no doubt, some positive correlation between the product attributes that are salient to one buyer and those that are salient to another. ${ }^{127}$ For example, in most product markets, price is probably salient to nearly all buyers, and whether the form contract includes a severability clause is probably salient to none (or almost none). Even so, it is undoubtedly the case that buyers will differ at times as to which attributes are salient and which are not, just as they will have different preferences for the content of those attributes. Relaxing the assumption that attributes salient to one buyer are salient to all buyers is thus necessary to make the analysis of the problem caused by buyer bounded rationality more realistic.

Assume that each buyer is willing to pay $\$ 15$ more for a highquality warranty term than a low-quality warranty term, and that a high-quality warranty costs sellers $\$ 10$ more to provide per customer. Thus, in this example, a high-quality warranty term is efficient. Assume also that the warranty term is salient to some buyers but nonsalient to others, and that each type of buyer is randomly distributed in the general population of buyers. Sellers in a competitive environment will then have to choose whether to appeal to the former type of buyer by offering widgets with a high-quality warranty at a higher price, or to appeal to the latter type by offering widgets with only a low-quality warranty for a lower price. If the warranty term is salient to nearly all buyers, of course, all sellers should offer a high-quality warranty-the efficient term. If the warranty term is salient to very few buyers, all sellers should offer low-quality warranties. If there are a substantial number of buyers of each type, it is likely that some sellers will offer high-quality warranties and others low-quality warranties, with each type of seller appealing to one of the two groups of buyers. While buyers for whom the warranty term is salient will re-

127 See Olshavsky, 24 Org Beh \& Human Performance at 311 (cited in note 75) (finding in an experimental setting that some product attributes were ignored by virtually all subjects). 
ceive an efficient warranty, buyers for whom the term is non-salient will receive an inefficiently low-quality warranty. ${ }^{12 x}$

These insights force a reconsideration of the inferences that should be drawn from the observation that sellers of a particular product all offer the same terms or, alternatively, from the observation that sellers offer different terms. As other commentators have observed, it is typical in many industries that all sellers offer identical, or at least substantially similar, form contract terms. ${ }^{129}$ The conventional economic wisdom is that such a state of affairs suggests that the terms are efficient for most or all buyers. ${ }^{130}$ Although this is a possible explanation, if the terms are low quality, it is also possible that the terms are inefficient but non-salient for most buyers. If it is commonly understood that a particular term is non-salient to most buyers, even the minority of buyers for whom the term is salient might decide to ignore or not even read the term because they can predict ex ante that all sellers will offer a low-quality version of the term. ${ }^{13 .}$ Thus, for every contract term in a particular product market, there is likely a tipping point at which a slight increase in the number of buyers for whom a term is non-salient causes most or all of the remaining buyers to ignore the term, even though it is salient for them. ${ }^{1.22}$

128 The "informed minority" argument contends that if even a minority of buyers shop for a particular attribute, all sellers in a competitive market will be forced to provide the efficient quality of that attribute. See Schwartz and Wilde, 69 Va L Rev at 1402-24 (cited in note 19); Grether, Schwartz, and Wilde, 59 S Cal L Rev at 300-01 (cited in note 48); Michael J. Trebilcock, The Limits of Freedom of Contract 120 (Harvard 1993). The problem with this argument is its implicit assumption that the uninformed majority is uninformed as to all terms and will buy whatever it is offered. In reality, if a particular contract term is salient to only some buyers, the buyers for whom the term is non-salient (the uninformed buyers) can be said to be shopping for a low price term, and thus these uninformed buyers will behave as if they prefer low-quality terms (because such terms permit the seller to offer a lower price). Thus, if the efficient contract term is "high quality," sellers have an incentive to provide a high-quality contract term (at a higher price) in order to compete for one group of buyers, but they have a competing incentive to supply a lowquality term (at a lower price) in order to compete for the other group of buyers. There is no reason to believe that sellers will cater to an "informed minority" when doing so will drive away the uninformed majority.

129 See, for example, Hillman and Rachlinski, 77 NYU L Rev at 435-36 (cited in note 2) (observing that consumers correctly perceive the "realit[y]" that a seller's "competitors usually employ comparable terms").

130 See, for example, id at 438 (claiming that businesses best understand how to allocate risks most efficiently, and that uniformity of contract terms across an industry should be expected because the best allocation of risks is likely to be similar for similar businesses).

131 See Avery Katz, The Strategic Structure of Offer and Acceptance: Game Theory and the Law of Contract Formation, 89 Mich L Rev 215, 288 (1990) (arguing that rational consumers will not bear the costs of reading form contracts because they know other consumers will not read them and terms will therefore be low quality); Rakoff, 96 Harv L Rev at 1228-29 (cited in note 4) (observing that if the widespread practice is for customers not to shop form terms, a particular customer who did so would only find that all drafting parties offer terms protective of the drafting parties).

132 A personal anecdote is relevant here. I recently complained to a purveyor of credit cards about a low-quality term buried in the fine print of a multi-page booklet describing the card's 
If, in contrast, sellers in a particular industry offer different form terms, the standard economic inference is that buyers have heterogeneous preferences, and that each set of terms offered is efficient for some buyers. But heterogeneity of terms is also possible if buyers have identical preferences for the content of certain terms but those terms are salient for some buyers and non-salient for others. If the heterogeneity of terms reflects heterogeneous preferences, all contracts might be efficient. If the heterogeneity of the terms' content reflects heterogeneity as to which terms are salient, however, contracts will only be efficient for customers for whom the terms are salient, while customers for whom the terms are non-salient will receive inefficient contracts.

3. Heterogeneous salience with adverse selection.

To complicate matters further, the nature of the terms that most often appear in form contracts suggests that buyers who find such terms salient might not be randomly distributed across the population of buyers. This could, in turn, skew sellers' choice of whether to appeal to the type of buyers who find a form term salient or the type who find a term non-salient.

Most terms embedded in form contracts allocate low-probability risks. Most products work as expected most of the time, and buyers have no more occasion to carefully consider and price the content of non-salient terms after purchase than they had before purchase. It is only infrequently that a buyer is unhappy with the performance of the product or is injured by it, and thus a warranty term or limitation on the extent of seller's liability becomes relevant, or that the seller believes the buyer has not satisfied her payment obligations and thus invokes terms that specify late fees, finance charges, collection procedures, and so on. It is even less frequent that litigation results, making relevant arbitration clauses or forum selection terms.

Whether these types of terms are ever invoked can conceivably depend on characteristics of the buyer, as well as on characteristics of the seller and the seller's product. Although circumstances will occur that cause a form term to become relevant regardless of the identity of the buyer, terms will become relevant more often for buyers in-

terms of use. A company representative told me that she had never heard this complaint and assured me that all the major firms in the industry use the same term. Assuming that both statements were true, one possible explanation is that the term is efficient. I strongly suspect a different explanation: (1) the term is non-salient to nearly all customers, who therefore have no reason to read and understand the content of the term; (2) customers for whom the term is salient assume that all sellers will offer the same term, so they have no reason to read the content of the term unless they are such marginal purchasers that the content of the term might cause them not to use credit cards; (3) few customers think they are on this margin; (4) therefore, all sellers face market pressure to offer a low-quality term. 
clined to search for product defects and problems, buyers with a low tolerance for such problems, buyers inclined toward invoking legal rights (including litigation) in case of conflict, and buyers inclined not to perform their obligations in the customary manner desired by the seller. If these buyers are both more likely than average to find form terms salient and less profitable on average to sellers-both reasonable assumptions - sellers will face an adverse selection problem. If a seller offers an efficient term that appeals to customers who find that term salient rather than offering an inefficient term at a lower price, that seller can expect to attract mostly undesirable buyers. If the adverse selection problem is severe, competition could cause all sellers to appeal to customers for whom such terms are non-salient. ${ }^{133}$ The result could be a substantial number of buyers for whom a term is salient who are unable to find any sellers offering the efficient term. ${ }^{1.4}$

This analysis suggests yet another plausible inference from the observation that all sellers in a given market offer a low-quality form term. The term might be efficient for all or nearly all buyers; it might be inefficient for some or many buyers but non-salient for most or all; or it might be inefficient for many and salient for some, but salient for buyers who tend to be undesirable customers in the view of sellers. In other words, there is very little cause for confidence that a form term is in fact efficient merely because it is dominant in a particular industry.

\section{E. Endogenous Changes in Salience}

A further complication to consider is that the status of a form term as salient or non-salient to a particular buyer is not necessarily static, but rather could change over time. This section considers the effects on the model of two dynamics that can affect the salience status of a term.

1. Experience and the consequences of reputation.

In most industries, sellers rely on repeat business from their customers and positive "word of mouth" to maintain profitability. This fact could mitigate the incentives that sellers have to offer low-quality

133 See Korobkin, 85 Cornell L Rev at 60-61 (cited in note 48).

134 Fear of adverse selection can, of course, affect sellers' behavior even when terms are salient to all buyers, as long as there is heterogeneity in buyers' preferences. For example, if some buyers prefer a mandatory arbitration term coupled with a lower price, and others prefer a higher price and no arbitration requirement, the number of sellers who choose to appeal to the latter type of buyers may be smaller than would otherwise be expected if that type of buyer is less profitable. Bounded rationality, however, can magnify the adverse selection problem because the group of buyers for which a term is salient and high quality is preferred is likely to contain a higher percentage of undesirable buyers than the larger group that merely prefers high quality. 
non-salient terms when those terms are inefficient. The idea is that employing an inefficient term can help the competitive seller to make the first sale or the monopolistic seller to maximize profit margin on the first sale, but this comes at the high cost of an unhappy customer who chooses not to patronize the seller again and complains to his friends. As long as the long-term costs exceed the short-term benefits, sellers will not, in fact, find it to be in their self-interest to offer inefficient terms. ${ }^{1.3}$ This argument implicitly relies on two assumptions: (1) terms that are non-salient to first-time buyers will become salient to repeat buyers and those with whom they communicate; and (2) sellers will desire the repeat patronage of the customers for whom nonsalient terms become salient. Both assumptions are questionable.

The types of terms that generally appear in form contracts suggest that the negative reputational consequences of inefficient nonsalient form terms are unlikely to discipline sellers to offer efficient terms. In the large majority of transactions in which the content of the boilerplate never becomes an issue, there is no reason to believe a non-salient term would suddenly become salient to a repeat buyer, or to anyone with whom the buyer communicates. ${ }^{13}$

In a small percentage of transactions, a problem or dispute occurs requiring the parties to invoke the content of one or more form terms. This experience could (but would not necessarily) cause the term at issue to become salient for an affected buyer in future transactions, and that buyer's discussions with others might cause the term to become salient for others in the future as well. If the content of the term is inefficient, this small number of buyers might be less inclined to patronize that seller in future transactions (assuming that enough other buyers already find the term salient to ensure that some sellers offer the efficient term), and perhaps their friends who learn about their experiences also will be less likely to do so. The costs of this small number of defections, however, is likely to be outweighed by the benefits gained from use of the inefficient term in contracts with the far larger number of buyers for whom the term never becomes salient. ${ }^{137}$

135 See, for example, Hillman and Rachlinski, 77 NYU L Rev at 444-45 (cited in note 2) ("[B]usinesses' concerns with their reputations often will dissuade them from attempting to exploit consumers with standard terms."); Patricia M. Danzon, Comments on Landes and Posner: $A$ Positive Economic Analysis of Products Liability, 14 J Legal Stud 569, 572 (1985) ("[R]epeat purchase undermines the argument that it is not rational for consumers to process information about low-probability events.").

136 See William M. Landes and Richard A. Posner, The Economic Structure of Tort Law 281 (Harvard 1987) ("A manufacturer will reap little consumer ill will from fooling consumers with a disclaimer that they fail to read, because product accidents are so rare anyway."); Cruz and Hinck, 47 Hastings L J at 663 (cited in note 16) ("[T]he probability of any single customer being affected by any given contract term is usually quite small.").

137 As an example, consider the cellular phone service industry, known for offering low nominal monthly prices that hide complicated pricing formulas and other "hidden" charges. Af- 
In addition, because a change in a term's status from non-salient to salient for a particular buyer could be viewed by sellers as a signal that the buyer is particularly difficult to please or quarrelsome, the seller might consider the loss of that buyer's patronage in future transactions a benefit rather than a cost. ${ }^{1.80}$ If this is not true and the seller wishes to insure the buyer's repeat patronage, the seller can waive its rights under the contract ex post (for example, by replacing a broken widget even though the contract disclaims liability), thus satisfying the buyer. ${ }^{1.34}$

\section{Advertising.}

Advertising, and similar attempts to draw the attention of buyers to a particular term, conceivably can make salient a term that otherwise would not be. Advertisements could persuade buyers that the advertised attribute is more important than buyers otherwise would have thought, convincing buyers that the term should become a focus of their limited attention. Alternatively, the mere presence of advertisements may attract buyers' involuntary attention and make the advertised attribute salient, even if buyers do not consider that attribute to be of primary importance in the purchase decision. ${ }^{140}$

A threshold problem with this premise is that in many situations no seller will have a sufficient incentive to invest in such an advertising campaign, even if the market currently supplies an inefficient term. In a perfectly competitive market, all sellers stand to benefit to the same degree from an attribute becoming salient to buyers, thus causing sellers to replace an inefficient combination of attribute and price with an efficient combination. In this circumstance, advertising is a public good, ${ }^{141}$ and no seller will wish to pay the cost of providing it.

ter signing service contracts, customers often become unhappy with the product they actually experience, leading to more than 40 percent of customers per year changing their service providers. See Barry Nalebuff and lan Ayres, Why Not?: How to Use Everyday Ingenuity to Solve Problems Big and Small 178-80 (Harvard Business 2003). Still, the industry seems undeterred.

138 See Korobkin, 85 Cornell L Rev at 60-62 (cited in note 48) (claiming that health insurance buyers who learn ex post about the gaps in coverage are likely to be sicker than the average buyer and thus that the seller will not desire their repeat patronage).

139 See Cruz and Hinck, 47 Hastings $\mathrm{L} J$ at 674 (cited in note 16) (noting that sellers can differentiate between customers ex post by giving more protection than the contract obligates to customers who complain loudly, but not to customers who do not complain but rather "lament their bad luck and foolishness" for not reading the contract at the time of purchase).

140 See Part II.C.2.

141 The features of public goods are the potential for nonrivalrous consumption and prohibitively high costs of excluding free riders. See Robert Cooter and Thomas Ulen, Law and Economics 42 (Addison-Wesley 3d ed 2000).

142 See, for example, Hanson and Kysar, 112 Harv L Rev at 1551-52 (cited in note 123); Kennedy, 41 Md L Rev at 601 (cited in note 15); Cruz and Hinck, 47 Hastings L J at 659 (cited in note 16$)$. 
If a seller has a competitive advantage in providing an efficient product attribute, however, it might be willing to invest in making the attribute salient for buyers. Assume, for example, that all buyers value red widgets at $\$ 100$ and white widgets at $\$ 50$. Producing a white widget costs all sellers $\$ 40$, and producing a red widget costs Firm $\$ 60$ and all other sellers $\$ 80$. If color is a non-salient attribute to buyers, in a competitive market all sellers will sell white widgets for $\$ 40$. If color is salient, however, sellers will provide red widgets for $\$ 80$ (plus the market rate of return on assets), and Firm will enjoy a supracompetitive profit of $\$ 20$ per widget. Similarly, some sellers might enjoy a competitive advantage in producing certain types of form terms. A seller that produces particularly sturdy widgets might be able to offer a high-quality warranty term at a lower cost than its competitors; a seller with a nationwide presence might be able to provide a forum selection clause that gives buyers a wide choice of forums at a lower cost than its competitors; and so on. If these terms are efficient, the seller with the competitive advantage will benefit if the terms become salient to buyers, thus providing that seller with an incentive to invest in encouraging salience.

Although there is no reason to believe that sellers can never change the product attributes that are salient to buyers when making purchasing decisions, ${ }^{143}$ there are a number of reasons to be skeptical that sellers will routinely succeed in such efforts. First, if the buyers most likely to find an attribute salient in response to advertising are likely to be unprofitable customers on average, sellers might choose not to promote that attribute. Thus, a firm with an in-house legal department that gives it a cost advantage in litigating rather than arbitrating disputes with its customers is not likely to launch an advertising campaign bragging that "you can sue us in court at any time without limitations." "144

Second, such marketing efforts will be costly, so sellers will have to balance the benefits of exploiting their competitive advantage against the cost of making the market responsive to it. Often, the value to a seller of making a term salient will be relatively small and

143 In fact, advertising might have produced such a shift in the area of automobile warranties. The landmark case of Henningsen $v$ Bloomfield Motors, Inc, 161 A2d 69, concerned an automaker's warranty buried in the "fine print" of the sales contract. Today, a large number of television advertisements focus on the quality of the automaker's warranty protection, and it is at least plausible that the warranties are salient to some substantial number of automobile purchasers.

144 See Goldman, $86 \mathrm{Nw}$ U L Rev at 719 (cited in note 46) (claiming that no cruise ship would advertise that it does not have a forum selection clause and that injured passengers could sue in any jurisdiction); Meyerson, $24 \mathrm{Ga} \mathrm{L} \mathrm{Rev}$ at 602 (cited in note 46) ("It is ludicrous to imagine a bank advertising, 'We have the only loan contract in town that doesn't require you to pay our attorneys fees if we successfully sue you for default."'). 
the cost of changing the way a substantial number of buyers shop for the product enormous. ${ }^{145}$ This is especially so in light of the fact that the amount of information that can be salient to buyers is subject to limitations and thus attributes usually can become salient only by squeezing out other attributes. ${ }^{146}$ If other sellers competing for buyers' attention are emphasizing other attributes, this competition could be quite expensive. In addition, in some situations, a seller's attempt to inform the public that it is breaking with the competition and offering a high-quality term might cause outrage by alerting the public to the fact that it has heretofore offered a low-quality term."

Finally, in a complex world in which products have many attributes, it seems likely that a seller could fail to make certain attributes salient no matter how many resources it expends on advertisingespecially attributes, like many form contract terms, that are unlikely ever to be invoked. A major advertising campaign stressing that "we offer the most customer-friendly forum selection clause" might cause buyers to notice forum selection clauses, but it seems highly unlikely to establish the forum selection clause as a salient term for many buyers, whatever the level of investment in the campaign.

\section{F. Conclusion}

Economic theories that predict form contracts will contain only efficient terms implicitly rest on the assumption that buyers will employ a thorough cost-benefit comparison - that is, one that is fully compensatory and non-selective-between all product alternatives that they consider. This fundamental assumption is implausible. Because of cognitive limitations, as well as external constraints on time and effort, all plausible decisionmaking approaches are necessarily boundedly rational.

Market pressure will produce low-quality non-salient attributes, regardless of whether low quality is efficient, because this allows sellers to compete on the always salient (or at least nearly always salient) attribute of price. When a term is salient to some buyers and nonsalient to others and high quality is efficient, sellers should offer different price/term combinations to appeal to one sector of the market or the other, meaning that some or many buyers will receive contracts

145 See Cruz and Hinck, 47 Hastings $\mathrm{L} J$ at 660 (cited in note 16) (noting that sellers are likely to bear the cost of advertising terms only in the atypical case of very expensive products).

146 Scholars who assume that the cause of inefficiency is insufficient exposure to information rather than limited processing capabilities assume that sellers can easily solve the problem by merely exposing buyers to relevant information. See, for example, R.H. Coase, The Choice of the Institutional Framework: A Comment, $17 \mathrm{~J}$ L \& Econ 493, 494-95 (1974) (claiming that sellers can simply explain to buyers the ways in which their terms are superior to competitors' terms).

147 See Kennedy, 41 Md L Rev at 601 (cited in note 15). 
with inefficient terms. If buyers for whom an attribute is salient tend to be unprofitable customers, fear of adverse selection may cause all sellers to appeal to customers for whom the term is non-salient. The incentive to offer low-quality non-salient terms might be mitigated to some extent by sellers' reputational concerns and the ability to make non-salient terms salient through advertising, but the potential of either of these factors to reduce the incentive to provide low-quality terms is likely to be limited and, even in the best case, will not be sufficient to completely offset that incentive.

The implication of this analysis is that, although the market should be expected to provide efficient salient contract terms to the advantage of buyers as a class and sellers as a class, no such assumption about non-salient terms is defensible. If the market for contract terms is unregulated, terms will suffer from a lemons problem, to the disadvantage of buyers and sellers. ${ }^{1.8}$ If this is to be avoided, state intervention into the otherwise private law of contract is necessary.

\section{RESPONDING TO BOUNDED RATIONALITY: ALTERNATIVES}

Form contracts will often contain inefficient terms because buyers' boundedly rational decisionmaking behavior will prevent the market from assuring that sellers offer only efficient terms. One potential policy response, of course, is for courts to enforce all form terms notwithstanding these market imperfections.

An unregulated market for form contracts should produce efficient terms to the extent to which terms are salient. Non-salient terms will tend to be low quality, but low-quality terms will sometimes be efficient (from an ex ante perspective, the likelihood is 50 percent), and both reputational concerns and competitor advertising should provide some limitations on sellers' incentives to provide inefficient lowquality terms. Private intermediaries that increase the salience of form terms to buyers and/or increase the reputational cost to sellers of providing low-quality terms might further reduce the market's tendency toward inefficiently low-quality terms. For example, if an organization provided a single rating of the overall quality of different sellers' contract terms, more buyers might find "term quality" a salient attribute.

148 While the quality implication of buyer bounded rationality is clear, it is unclear whether buyer bounded rationality results in an inefficiently large quantity of purchases. If buyers believe form terms give them more protection than the terms actually provide, then an unregulated market would produce inefficient overconsumption of goods and services accompanied by form terms, as buyers as a class would wish to purchase less quantity if they understood true quality. However, if buyers believe that form terms are low quality, current quantities purchased should be efficient given quality. If regulation were to improve the quality of terms, and buyers understood this, buyers would purchase a larger, but still efficient, quantity of the relevant goods and services. If regulation were to improve the quality of terms but buyers continued to expect lowquality terms, the result could be inefficient underconsumption. 
Finally, non-salient terms will tend to be relatively less important to buyers than salient terms, which suggests the cost of inefficient terms might be relatively low. ${ }^{199}$ Despite the likelihood that the unregulated market will produce inefficiently low-quality terms, then, it is not obvious a priori that the market would lead to worse results than available alternatives, judged either by the metric of social welfare or buyer welfare. The virtues and vices of government intervention must be compared carefully to those of non-intervention.

Three regulatory alternatives to blanket enforcement of form terms exist: (1) require buyers and sellers to negotiate fully statecontingent contracts; (2) impose legislatively determined mandatory terms on contracting parties; (3) judicially evaluate and replace form terms ex post, on a case-by-case basis. This Part critically evaluates these three policy options. The first option is impractical and, in any event, would not solve the problems created by buyer bounded rationality. The second, while plausible, cannot be a complete solution to the problem. The third would strain judicial competence and, at the extreme, would impose an unacceptable level of uncertainty on contracting parties.

This Part concludes that the best response to the problem of buyer bounded rationality is to combine elements of the second and third solutions by increasing the use of mandatory terms and, concurrently, relying on limited judicial review of seller-drafted terms. This approach seeks to capitalize on the relative institutional advantages of markets, legislatures, and courts. Part IV evaluates how well the judicial doctrine of unconscionability, as currently applied, serves this approach, and Part V proposes specific reforms to the unconscionability doctrine.

\section{A. Obligationally Complete Contracting}

One alternative to enforcing form contract terms unilaterally imposed on buyers by sellers is to require contracting parties to negotiate complete, state-contingent contracts item by item. Failure of the parties to produce completely "dickered" contracts would result in refusal by the courts to enforce the agreements.

149 This point should not be overstated, for three reasons. First, the terms most important to buyers will not necessarily be the terms for which there is the greatest difference between the buyer's value and seller's cost (and therefore subject to the greatest inefficiency). Second, the terms most important to buyers will not always be the terms that are salient (see Part II.C.2). Third, even assuming the efficiency costs of non-salient terms are low relative to the efficiency costs of salient terms, the absolute size of these costs could be quite large.

150 See Russell Korobkin, The Status Quo Bias and Contract Default Rules, 83 Cornell L Rev 608,673-75 (1998) (suggesting that courts use nonenforcement default rules to force parties to fill contractual gaps). 
Form contracts exist, of course, because of the substantial transaction cost savings that they produce. ${ }^{1.1}$ A requirement that all contracts be individually negotiated would increase transaction costs so substantially that many common and productive transactions would be rendered economically unfeasible, potentially causing commerce to grind to a halt. ${ }^{1.2}$ For this reason, no court or scholar seriously considers such a requirement.

A variation on this theme might be possible, however. Courts could require sellers to procure specific assent to each boilerplate clause in a form contract, perhaps by having buyers initialize each paragraph. ${ }^{1.53}$ An obvious drawback to this approach is that, while perhaps not impossible, it still would be quite costly. More significantly, however, a specific assent requirement would not solve the problem of inefficiency in form contract terms. If individuals are capable of considering only a limited number of attributes in a typical decisionmaking situation, ${ }^{154}$ buyers who might otherwise completely ignore or not even read non-salient form terms are likely to passively accept sellers' proposals for non-salient terms. A specific assent requirement might ensure actual notice, but it will not ensure salience. Specific assent to a single term in a sea of boilerplate might (but will not necessarily) succeed in making that term salient to a significant number of buyers by drawing attention to it, but specific assent to dozens of boilerplate terms is unlikely to have any effect on contractual efficiency.

This point is extremely important, because it underscores a difference in policy prescription that flows from an understanding that contractual inefficiency results primarily from suboptimal information processing rather than from incomplete information. Although scholars previously have recognized that contract terms might be inefficient if buyers lack sufficient information about those terms, ${ }^{1,5}$ most have assumed that buyer understanding of specific terms should be a sufficient condition for enforcement of those terms. ${ }^{1.56}$ And, as a result,

151 See Posner, Economic Analysis of Law $\$ 4.8$ at 115-16 (cited in note 25); Coase, $17 \mathrm{~J}$ L \& Econ at 494 (cited in note 146); Stephen J. Ware, Comment, A Critique of the Reasonable Expectations Doctrine, 56 U Chi L Rev 1461, 1477 (1989).

152 See Slawson, 84 Harv L. Rev at 552 (cited in note 1) ("Under what conceivable calculus of social value ... would it be worthwhile to raise the price of a ten-cent consumer product enough to cover the cost of individually negotiating the warranty of each one sold...?").

153 See Eisenberg, $59 \mathrm{~S} \mathrm{Cal} \mathrm{L} \mathrm{Rev} \mathrm{at} 311$ (cited in note 45) (suggesting that form terms be enforced only when "separately signed" by buyers).

154 See Part II.C.

155 See note 47.

156 See, for example, Slawson, 84 Harv L Rev at 545 (cited in note 1); Meyerson, $47 \mathrm{U} \mathrm{Mi-}$ ami L Rev at 1299 (cited in note 9) (concluding that buyers should be bound to form terms that they "know and comprehend"); Seita, 46 U Pitt L Rev at 130 (cited in note 9) (arguing that strong default rules should be enforced unless the consumer knows and approves of an alternate term); Meyerson, $24 \mathrm{Ga} \mathrm{L} \mathrm{Rev} \mathrm{at} \mathrm{612-13} \mathrm{(cited} \mathrm{in} \mathrm{note} \mathrm{46)} \mathrm{(stating} \mathrm{that} \mathrm{a} \mathrm{consumer's} \mathrm{actual}$ 
these scholars often focus policy prescriptions on reducing information costs. ${ }^{157}$ If buyer bounded rationality is the source of contractual inefficiency, however, inefficiency can exist even when buyers have actual and specific notice of the content of form terms, and the problem cannot be solved by legal regulations that merely reduce the cost to buyers of learning about the content of terms. ".8. To reiterate, "notice" is not the same as "salience."

\section{B. Ex Ante Mandatory Terms}

Form contracts could be superseded by legislatively enacted mandatory - that is, nonwaivable-contract terms that would govern the relationship between buyers and sellers. Rather than enforcing adhesive terms on pre-printed forms or requiring parties to negotiate or prove specific assent to each term, the state would dictate the content of such terms ex ante by enacting a set of terms to make up the fine print of various types of contracts.

Mandatory contract terms are already plentiful, of course, although they do not begin to challenge the dominance of the form contract as the source of contract law. Some mandatory terms are explicitly part of contract law. ${ }^{100}$ Others are established by state or federal

knowledge of a term justifies its enforcement).

157 See, for example, M.J. Trebilcock, The Doctrine of Inequality of Bargaining Power: PostBenthamite Economics in the House of Lords, 26 U Toronto L Rev 359, 373 (1976) (recommending legal rules governing disclosure, conspicuousness, and intelligibility of form terms in response to the problem of suboptimal information); Meyerson, $24 \mathrm{Ga} \mathrm{L} \mathrm{Rev} \mathrm{at} \mathrm{610-11} \mathrm{(cited} \mathrm{in} \mathrm{note} \mathrm{46)}$ (asserting that legal reform should focus on encouraging sellers to share information with consumers). But see Schwartz and Wilde, $127 \mathrm{U}$ Pa L Rev at 667,673 (cited in note 23) (arguing that regulation of contract terms is undesirable when consumers can "conveniently be informed" of the content of terms and that " $[t]$ he most promising method of making markets behave competitively is to provide consumers with comparative price and term information").

158 See Rachlinski, 97 Nw U L Rev at 1176-77 (cited in note 110) (noting that disclosure requirements to ensure "individuals have more information" is a cure for informational asymmetries but cognitive errors may require more invasive policy responses). But see Schwartz and Wilde, 127 U Pa L Rev at 635 (cited in note 23) (noting that many consumer protection laws require disclosure of information to consumers rather than mandating contract terms).

159 This is essentially the proposal advanced by Todd Rakoff, who argues that form contract terms should be presumptively invalid and the government should provide "gap-filler" terms to fill the resulting gaps in the parties' contractual obligations. See Rakoff, 96 Harv L Rev at 1220 48 (cited in note 4). See also Donald B. King, Standard Form Contracts: A Call for Reality, 44 SLU L J 909, 915-16 (2000) (stating that terms not discussed and agreed on by both parties should not be enforced-gap-filling provisions of the UCC should govern other matters). The Standard Form Contract Act, recently proposed by the New Jersey Law Review Commission to that state's legislature (but not yet adopted), attempts to operationalize this idea. See A 3161, 208th Legislature (NJ 1999), and A 978, 209th Legislature (NJ 2001), both online at http://www.njleg.state.nj.us (visited Aug 24, 2003). Aspects of this proposal are discussed at notes 177-82 and accompanying text.

160) See, for example, UCC $\$ 2-718(1)$ (ALI 2002) (limitations on liquidated damages provisions); id $\S 2-719$ (3) (prohibition on limitations of consequential damages for personal injury in consumer contracts). 
consumer protection statutes that regulate specific types of contracts ${ }^{161}$ or specific types of contractual terms. ${ }^{1.2}$ More still mandate certain elements of a bargain in specific contexts and are not generally thought of as being contract law at all. ${ }^{163}$ The implied warranty of habitability, for example, establishes a duty of landlords to tenants that the parties cannot contract around, either by form or dickered term. ${ }^{164}$ The law prohibits employers from firing employees for certain reasons, ${ }^{165}$ thus placing limits on the ability of employers and employees to contract for "at will" employment. ${ }^{\text {iof }}$ All fifty state governments and the federal government have enacted "mandated benefits" laws, which require providers of health insurance to contract with all of their customers for certain health care services and benefits. ${ }^{107}$

Efficiency determinations are often extremely difficult to make, because changing the content of a contract term can have secondary incentive effects on buyers or sellers that are hard to evaluate with any degree of precision. ${ }^{1.8}$ This fact explains why law-and-economics scholars usually recommend that the market determine contract terms rather than government actors. ${ }^{169}$ But buyer bounded rationality can result in the market providing sellers with a profit incentive to draft inefficiently low-quality form terms. Legislatures have no such incentive, and they can thus focus their full attention on drafting efficient terms. If the well-known drawbacks of legislative decisionmaking identified by public choice theory are considered significant obstacles

161 See, for example, Truth in Lending Act, 15 USC $\S 1601$ et seq (2000) (consumer credit cost disclosure).

162 See, for example, Magnuson-Moss Act, 15 USC $\$ 2301$ et seq (2000) (warranties for consumer products); Consumers Legal Remedies Act, Cal Civ Code $\S 1750$ et seq (West 1998) (mandatory provisions concerning attorneys' fees and cost shifting in consumer litigation).

163 For an excellent general discussion, see Kennedy, 41 Md L Rev at 590-96 (cited in note 15$)$.

164 See, for example, Cal Civ Code $\$ \S 1941,1942.1$ (West 1998) (requiring leased property to be fit for habitation unless part of the consideration for the lease is an agreement by the tenant to make repairs).

165 See, for example, Mark A. Rothstein, et al, 1 Employment Law $\S 3.10$ at 185-88 (West 1994) (describing the legal claim for discrimination in discharge); id $\S 3.1$ at 149 (describing federal statutes prohibiting employment discrimination based on race, national origin, gender, age, or disability); Mark A. Rothstein, et al, 2 Employment Law $\S 9.18$ at 296-303 (West 1994) (describing "whistleblower" and anti-retaliation statutes).

166 See Rothstein, et al, 1 Employment Law $\S 1.4$ at 12-15 (cited in note 165) (discussing the at-will employment doctrine).

167 See Korobkin, 85 Cornell L Rev at 2-3 (cited in note 48).

168 See Richard Craswell, Remedies When Contracts Lack Consent: Autonomy and Institutional Competence, 33 Osgoode Hall L J 209, 225 (1995). See also Priest, 90 Yale L J at 1310-11 (cited in note 33) (explaining how efficient warranty terms depend on the costs to manufacturers of making the product harm resistant, costs to consumers of avoiding harm, and costs to both of different varieties of insurance against harm).

169 See Schwartz, 63 Va L Rev at 1066-67 (cited in note 31) (claiming that sellers are better than courts in determining consumer preferences). 
to legislatures actually attempting in good faith to mandate efficient terms, ${ }^{171}$ legislatures can delegate the task of identifying specific terms to an expert agency that is more insulated from interest-group politics. ${ }^{17}$

Legislatures (or their expert-agency delegates) also have certain institutional advantages in promulgating contract terms relative to courts. If the goal of imposing mandatory terms is to maximize the efficiency of contracts for the greatest percentage of parties possible, legislatures are likely to be more institutionally competent to consider the preferences of the entire range of contracting parties than judges who, due to the nature of the litigation system, must establish rules in the context of considering individual disputes. ${ }^{172}$

The potential benefits of mandated terms, however, carry with them a substantial drawback. Ex ante mandatory terms, by their nature, are not precisely tailored to specific contextual situations. The less context-specific a term, the more likely that the term will serve to allocate responsibilities and risks between the contracting parties in an inefficient way. For example, the statute proposed by the New Jersey Law Revision Commission would prohibit a seller from transferring to the buyer any risk exceeding the value of the purchase. ${ }^{133}$ The proposal's report explains, as an example, that a person who rents a lawn tiller for $\$ 100$ could not be made liable for more than $\$ 100$. $^{174}$ While this might be an efficient rule for lawn tillers (assuming, for example, that lessors typically can spread the cost of insurance and that user error rarely or never damages a tiller), it might be an inefficient rule in another setting-perhaps auto rentals, assuming that auto renters can substantially affect the likelihood of damage by their choices of where to drive and park. A one-size-fits-all mandatory term cannot help but be inefficient for at least some contracts.

170 Public choice theory suggests that legislative pronouncements may be based on interestgroup politics rather than complete dedication to the public good. See Korobkin, 85 Cornell $\mathbf{L}$ Rev at 80-83 (cited in note 48) (considering the impact of public choice on "patient protection" statutes); Daniel A. Farber and Philip P. Frickey, The Jurisprudence of Public Choice, 65 Tex L Rev 873, 890-901 (1987) (describing the influence of special interests on legislation).

171 See Korobkin, 85 Cornell L Rev at 83-87 (cited in note 48) (recommending that expert commissions be appointed to determine mandatory terms in health insurance contracts).

172 In theory, legislative bodies or their agents have better access to market-wide data, which can allow them to conduct a more informed cost-benefit analysis of potential mandatory terms, than do courts attempting to resolve disputes between specific litigants. In practice, of course, it is far from clear that legislatures would determine the content of mandatory terms by references to such an efficiency criterion. For example, a recent article by Senator Russell Feingold calls for legislation prohibiting the enforcement of arbitration clauses without a single word considering the ex ante benefits of such terms to buyers in the form of lower prices or attempting to compare these benefits to the costs of mandatory arbitration. See Russell D. Feingold, Mandatory Arbitration: What Process Is Due?,39 Harv J on Legis 281 (2002).

173 Burke, 24 Seton Hall Leg J at 317 (cited in note 3).

174 Id. 
Legislatures could mitigate this problem by drafting a more complex set of rules that tailor the content of mandatory terms to casespecific facts. ${ }^{175}$ For example, there could be a different risk allocation rule for rentals of cars than for rentals of lawn tillers. Consistent with this approach, a host of bills have been introduced in the Congress in recent years that would prohibit mandatory arbitration in a variety of specific contractual contexts. ${ }^{176}$ But at some point, as distinctions become finer and exceptions to rules and exceptions to the exceptions proliferate, legislation becomes unwieldy.

The idea of mandating contract terms ex ante thus creates the following dilemma: On one hand, devising a complete set of mandatory contract terms ex ante would be possible, but the unavoidable lack of tailoring would ensure that the terms would not allocate risks and responsibilities efficiently for some parties, and possibly for many. On the other hand, although it is theoretically possible to define ex ante an efficient set of mandatory terms by tailoring the terms to an infinite number of "triggering facts," doing so would be a practical impossibility.

The New Jersey Commission's proposed statute attempts to deal with this problem by combining ex ante rules with ex post standards. For example, the proposal finds that arbitration is efficient and permits mandatory arbitration clauses, but with the caveat that arbitration fees may not be "unreasonably high." ently believed that a simple rule permitting arbitration clauses would be too general and a complex rule specifying the precise level of fees that should trigger invalidation under different circumstances would be too complicated to spell out in a statute. The result requires judges to determine, on a case-by-case basis, whether or not arbitration fees are excessive. The European Union, through its Unfair Terms in Consumer Contracts Directive, ${ }^{17 \pi}$ adopts a different approach to the problem of drafting ex ante mandatory terms. Rather than combining ex ante rules with ex post standards, the directive provides a very broad ex post standard prohibiting "unfair terms," but includes a list of specific terms that might typically be regarded as unfair that is illustrative

175 See generally Russell B. Korobkin, Behavioral Analysis and Legal Form: Rules vs. Standards Revisited, 79 Or L Rev 23, 25-30 (2000) (creating a spectrum of "rules" and "standards").

176 See, for example, Civil Rights Procedures Protection Act of 2001, S 163, 107th Cong, 1st Sess, in 147 Cong Rec S 530 (Jan 24, 2001) (employment contracts); Motor Vehicle Franchise Contract Arbitration Fairness Act of 2001, S 1140, 107th Cong, 1st Sess, in 147 Cong Rec S 719596 (June 29, 2001); Consumer Credit Fair Dispute Resolution Act of 2001, S 192, 107th Cong, 1st Sess, in 147 Cong Rec S 587 (Jan 25, 2001).

177 See Burke, 24 Seton Hall Leg J at 316 (cited in note 3).

178 Council Directive 93/13/EEC of 5 April 1993, 36 Off J Eur Communities, No L 95/29 (Apr 21, 1993). 
but not legally binding. ${ }^{177}$ The critical observation is that neither the European Union nor the New Jersey Commission attempted to specify ex ante the complete content of its rules concerning the enforceability of arbitration clauses.

Just as it is difficult for legislatures to provide completely tailored content of a specific type of term, such as dispute resolution provisions, ex ante, it would also be difficult for legislatures to provide a complete set of mandatory contract terms ex ante. Although a handful of form terms, such as arbitration, warranty, and damages-limitation clauses are common, an infinite number of possible terms could potentially appear in a form contract, many of which even a lengthy statute could not anticipate. ${ }^{1.80}$ For these less-common terms not explicitly provided for ex ante, mandatory terms are not a viable option. The New Jersey proposal also illustrates this problem. It mandates content for six types of common terms and then-borrowing from section 211 of the Restatement (Second) of Contracts ${ }^{1 \times 1}$ - provides that all other form terms are enforceable unless a reasonable buyer would have declined the transaction had he known of the content of the term. ${ }^{1.2}$

In sum, replacing seller-provided form terms with ex ante mandatory terms has the advantage of allowing legislatures or their appointed agents to choose contract terms rather than sellers, who have an incentive to provide low-quality non-salient terms (whether or not efficient), or judges, who are probably less institutionally competent than legislators to identify efficient terms. But ex ante mandatory terms cannot be perfectly tailored to the efficiency requirements of context-specific market circumstances, and legislators are unlikely to be able to promulgate ex ante content for the nearly infinite types of terms that can appear in form contracts.

These drawbacks suggest that while ex ante mandatory terms should be an element of any government response to the market failures that result from non-salient terms, they cannot and should not be expected to be the complete response. More specifically, ex ante mandatory terms are desirable when a simple rule ${ }^{183}$ or an only moderately

179 For a more thorough description, see A. Brooke Overby, An Institutional Analysis of Consumer Law, 34 Vand J Transnatl L 1219, 1263-71 (2001).

180 See Robert A. Hillman, Debunking Some Myths about Unconscionability: A New Framework for U.C.C. Section 2-302, 67 Cornell L Rev 1, 28 (1981) (asserting that "legislators cannot successfully draft legislation to encompass unforeseen circumstances").

181 For a discussion of the Restatement (Second) $\$ 211$ rule, see Part IV.A.4.

182 See Burke, 24 Seton Hall Leg J at 323-25 (cited in note 3) (discussing the New Jersey proposal's default rule).

183 For example, "forum selection clauses are never enforceable." For a defense of such a rule based on an argument that forum selection clauses are almost never efficient, at least when the buyers are consumers, see Goldman, $86 \mathrm{Nw}$ U L Rev at 716-34 (cited in note 46). 
complicated rule ${ }^{1 / 4}$ can insure that the mandated content will be efficient for a relatively large proportion of contracts. When only an exceedingly complicated rule can ensure efficient content for the large majority of contracts, and when particular terms are product- or sellerspecific and unlikely to appear in a large number of form contracts, ex ante mandatory terms will not provide a satisfactory solution to the problem of non-salience.

\section{Ex Post Mandatory Terms}

Rather than legislatures mandating contract terms ex ante, courts could replace seller-drafted terms ex post-that is, after a dispute arises between a buyer and a seller. ${ }^{1 \mathrm{kS}}$ Such retrospective review could be operationalized in a variety of ways, with differing degrees of associated costs. This section considers three specific possibilities.

\section{Fully tailored terms.}

In theory, courts could respond to disputes by enforcing terms that are efficient for the particular disputing parties from an ex ante perspective and refusing to enforce terms that are inefficient for those parties. Once a term was challenged by a buyer, the court would essentially rewrite the contract de novo. The benefit of such complete tailoring is that courts could take into account the full range of contextual factors that affect the costs and benefits of terms to both buyer and seller and include in the revised contract only efficient terms. ${ }^{1.60}$

The costs of complete tailoring obviously would be so significant as to render the enterprise impractical. For any term, no matter how efficient for most buyers, there always would be a high likelihood that a particular buyer could demonstrate it to be inefficient in her individual transaction and thus unenforceable. Thus, sellers would face penalties even when they provided the most efficient terms possible while still taking advantage of the cost savings of using a standard form. The only way to avoid this likelihood would be to custom-tailor terms for each buyer, an obvious impossibility for all but the highestvalue transactions.

184 For example, "lawsuits may be brought only in the forum state in which the seller is domiciled, unless the seller employs at least ten workers in the state in which the buyer is domiciled, in which case lawsuits may be brought in that state as well."

185 This role also could be filled by an administrative agency performing a judicial function.

186 This is the primary benefit of any ex post "standards" relative to ex ante "rules." For a discussion, see Korobkin, 79 Or L Rev at 25-30 (cited in note 175). 


\section{Tailoring to product markets.}

Ex post review would be a coherent approach if courts inquired into whether a particular term was efficient for the majority of transactions within a particular product market, rather than for a particular single transaction. Under this approach, sellers would not be penalized merely for offering standard terms to all buyers, but courts would refuse to enforce seller-drafted terms that are inefficient ex ante for most of the transactions that the form covers.

This approach is plausible, but the problem is that requiring courts to determine de novo whether particular terms are efficient or inefficient would strain the bounds of judicial competence and invite a high error rate. ${ }^{187}$ As noted above, efficiency determinations are difficult for any government institution to make. ${ }^{13}$ Courts, however, are particularly poorly positioned to make them. Asked to resolve a dispute between specific parties, courts usually will lack necessary information concerning how a certain market functions, the cost structure of its sellers, and the subjective preferences of its buyers, all of which are necessary to determine which of several possible terms is efficient. ${ }^{1 \times 0}$

Because courts called on to make efficiency determinations are likely to err frequently, asking courts to pass on the efficiency of all contract terms challenged by a buyer would create tremendous uncertainty. It would be hard for drafting parties to be confident that any of their form terms would be enforceable, thus making it difficult for sellers to estimate the costs of their obligations and set prices accordingly. Although difficult to demonstrate analytically, this large uncertainty cost would likely outweigh the benefits of judicial review of all form terms, relative to the options of enforcing all form terms or legislating mandatory terms ex ante.

\section{Tailoring, with deference.}

A more pragmatic option - that is, one that strikes a balance between the desire to abrogate inefficient form terms ex post and the

187 Many authors, dating back at least to Karl Llewellyn, have noted that a primary drawback to the judicial policing of contract terms is that courts will have substantial difficulty distinguishing efficient from inefficient terms. See Llewellyn, 52 Harv L Rev at 704 (cited in note 9). See also Hillman and Rachlinski, 77 NYU L Rev at 441 (cited in note 2); Schwartz and Wilde, $127 \mathrm{U}$ Pa L Rev at 678-82 (cited in note 23).

188 See Part III.B.

189 As Duncan Kennedy has put the point, debates about the efficiency of competing terms "all depend[] on empirical data that no one ever seems to have ready at hand." Kennedy, $41 \mathrm{Md}$ L Rev at 603 (cited in note 15). See also Stephen Ware, Paying the Price of Process: Judicial Regulation of Consumer Arbitration Agreements, $2001 \mathrm{~J}$ Disp Resol 89, 91 (reporting that there are no publicly available studies concerning whether arbitration clauses save businesses money). 
practical need for some measure of certainty among contracting parties as to their rights and responsibilities - is for courts to retain the ability to invalidate ex post form contract terms particularly likely to be inefficient, while privileging from judicial evaluation form contract terms unlikely to be inefficient. In other words, while courts evaluate a limited set of terms most likely to be inefficient de novo, they view other terms with a high degree of deference and enforce them without substantive review. The unconscionability doctrine, as it is currently applied by most courts, provides a model for this type of dichotomous judicial analysis. Courts usually search for "substantive unconscionability" only when there is evidence of a procedural defect in the bargaining process. Without evidence of "procedural unconscionability," courts generally defer completely to seller-drafted terms. ${ }^{130}$

Part IV reviews in detail the courts' current approach to the judicial review of form contracts terms, dominated by the unconscionability doctrine. It concludes that, although it is sensible for courts to use an initial procedural screen and then to conduct substantive scrutiny of contract terms identified by that screen as suspect, neither the "procedural" nor the "substantive" prong of the unconscionability doctrine, as presently understood, is particularly well-tailored to promoting social efficiency or buyer well-being. Part $\mathrm{V}$ then proposes reforms to the implementation of the unconscionability doctrine to promote a tighter fit between the doctrine and the primary cause of contractual inefficiency.

\section{Conclusion}

Requiring specific assent to all form terms would not remove inefficient terms from form contracts, as all product attributes still would not be salient to buyers. Legislatures (or expert agencies) could mandate the content of some contract terms ex ante, but such terms could not be tailored to different contracting contexts specifically enough to always be efficient. Courts could review all contract terms for efficiency, but such a process would be extremely costly and subject to error.

The most sensible approach is a combination of market, legislative, and judicial action designed to capitalize on the advantages and minimize the disadvantages of all three institutions. ${ }^{191}$ When circumstances suggest a form term is likely to be salient to buyers, courts should enforce the seller-drafted term, because in those situations

190 In some jurisdictions, courts have exhibited a willingness to find particularly egregious terms unconscionable without any evidence of "procedural unconscionability," see Part IV.A, but this is the exception rather than the rule.

191 See Figure 3. 
market forces are more likely to result in efficiency than either legislative or judicial estimations of efficiency. When terms are non-salient to buyers and party or industry eccentricities are unlikely to bear on the efficient content of those terms, legislatures should mandate their content. When terms are non-salient but the efficient content of those terms is likely to vary significantly across contracts, courts should review those terms for efficiency on a case-by-case basis, because in that situation judicial determinations are more likely to lead to efficiency than either market forces or ex ante legislative mandates.

\section{Figure 3}

Relative Institutional Competence

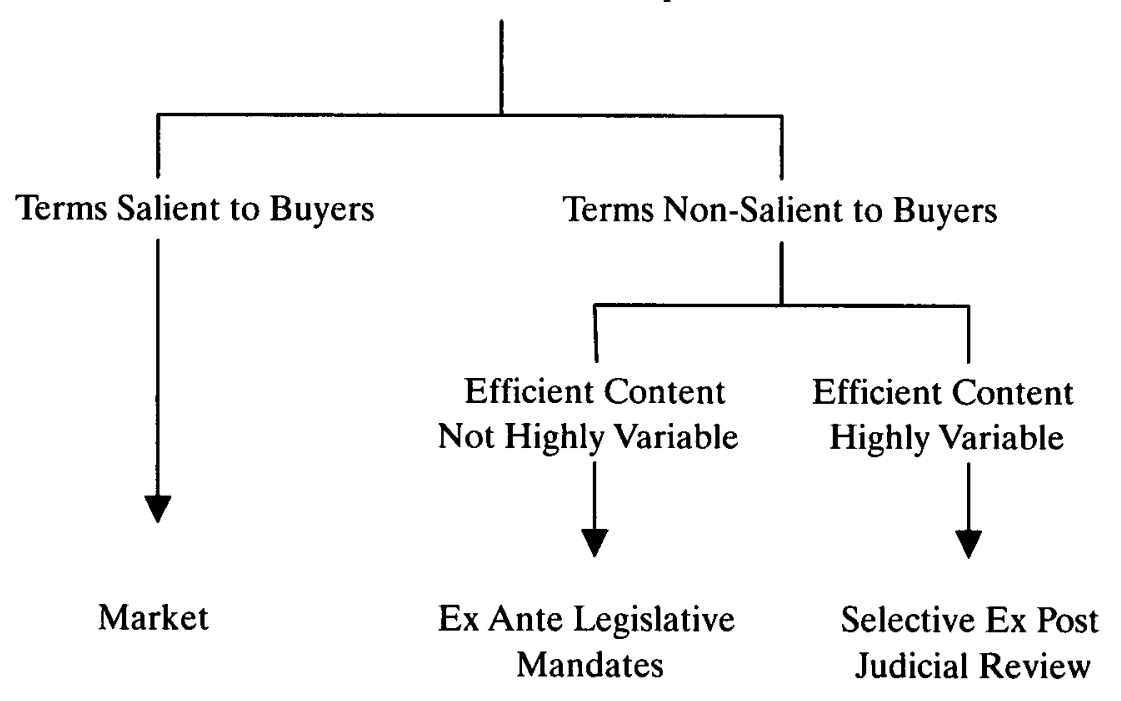

IV. THE JUdicial TREATMENT OF Form CONTRACTS

Traditionally, the terms included in a form contract signed by the buyer were enforceable as written absent a valid common law formation defense such as fraud, duress, or undue influence. ${ }^{192}$ That is, they were subject to no closer scrutiny than fully dickered contract terms. While a strong presumption of enforceability remains, courts examine form contracts with a heightened level of scrutiny in some circumstances and refuse to enforce some form terms. This Part considers whether the doctrine applied by courts is appropriately tailored to the

192 See Restatement of Contracts $\S 70$ (1932); E. Allen Farnsworth, Contracts $\S 4.26$ at $312-$ 13 (Little, Brown 2d ed 1990). 
source of contractual inefficiency, as identified in Part II, and concludes that it is not.

The equitable doctrine of unconscionability, revitalized by its enactment as part of the Uniform Commercial Code (UCC) ${ }^{103}$ and subsequently expanded by analogy by courts in most states to non-sales contracts, ${ }^{1 / 4}$ is the primary doctrinal implement used by courts to reject terms embedded in form contracts. The doctrine permits courts to deny enforcement of any contract or contract clause it determines was "unconscionable" at the time it was made." Although the UCC does not provide a definition of the term unconscionability, and courts do vary in how they interpret the term, most courts have held that the doctrine may be invoked only on a finding of both imperfections in the bargaining process, known as "procedural unconscionability," and an unfairly one-sided term, referred to as "substantive unconscionability."

A useful way to think about this dual-pronged approach is that a court's inquiry into the enforceability of a substantive term is triggered by the identification of a defect in the bargaining process that renders the substance of the contract particularly suspect, usually assumed to mean undesirable for the buyer. Courts have been willing to

193 See UCC $\$ 2-302$.

194 See Restatement (Second) of Contracts $\$ 208$ (1981); Weaver v American Oil Co, 257 Ind 458,276 NE2d 144, 145-48 (1971) (striking clause as "unconscionable" in a non-sale-of-goods context after determining that the clause would have been unconscionable under UCC \$ 2-302 had it appeared in a contract for the sale of goods).

195 The UCC specifically provides that, as an equitable doctrine, the unconscionability determination is made by courts as a matter of law rather than by juries as a matter of fact. UCC $\S 2-302$ comment 3. See also County Asphalt, Inc v Lewis Welding and Engineering Corp, 444 F2d 372,378 (2d Cir 1971) (holding that the court, not the jury, should decide the issue of unconscionability, which is an equitable doctrine); UCC \$ 2-302(1).

196 See, for example, Harris v Green Tree Financial Corp, 183 F3d 173, 181 (3d Cir 1999); Rosenberg v Merrill Lynch, 170 F3d 1. 17 (1st Cir 1999); Andersons, Inc v Horton Farms, Inc, 166 F3d 308, 322 (6th Cir 1998); Williams v Walker-Thomas Furniture Co, 350 F2d 445, 449 (DC Cir 1965); Armendariz v Foundation Health Psychcare Services, Inc, 24 Cal 4th 83, 6 P3d 669, 767 (2000); Iwen v US West Direct, 293 Mont 512, 977 P2d 989, 995 (1999); Powertel, Inc v Bexley, 743 S2d 570, 574 (Fla App 1999); Dorsey v Contemporary Obstetrics and Gynecology Inc, 113 Ohio App 3d 75, 680 NE2d 240, 243 (1996). See generally Leff, 115 U Pa L Rev at 487 (cited in note 5) (coining the terms "procedural" and "substantive" unconscionability). This generalization that both procedural and substantive unconscionability are necessary, like every generalization that can be made about the application of the unconscionability doctrine, has exceptions. See, for example, East Ford Inc $v$ Taylor, 826 S2d 709, 715 (Miss 2002) (holding that when a term is found procedurally unconscionable, substantive unconscionability analysis is unnecessary), cert denied, 123 S Ct 1302 (2003); Brower v Gateway 2000, Inc, 246 AD2d 246, 676 NYS2d 569 (NY App Div 1998) (finding arbitration term unconscionable based solely on substance, with no finding of procedural unconscionability); Sosa v Paulos, 924 P2d 357, 361 (Utah 1996) ("Gross disparity in terms, absent evidence of procedural unconscionability, can support a finding of unconscionability."), quoting Resource Management Co v Weston Ranch, 706 P2d 1028, 1043 (Utah 1985); Gillman v Chase Manhattan Bank, NA, 73 NY2d 1, 534 NE2d 824, 829 (1988) (suggesting that procedural imperfections may not be necessary if a term is substantively "outrageous"). 
find procedural unconscionability and thus investigate the substance of form terms either when a buyer's acceptance of the form terms was not truly voluntary ${ }^{197}$ or a buyer was unfairly surprised ${ }^{198}$ by the content of the terms in the form he signed. This Part first critically examines the factors that courts have ruled satisfy the procedural prong of the unconscionability doctrine. It then examines and critiques what courts have determined constitutes substantive unconscionability.

197 See, for example, Entergy Mississippi, Inc v Burdette Gin Co, 726 S2d 1202, 1207 (Miss 1998), quoting Bank of Indiana NA v Holyfield, 476 F Supp 104, 109 (SD Miss 1979); John Deere Leasing Co v Blubaugh, 636 F Supp 1569, 1573 (D Kan 1986) ("The indicators of procedural unconscionability generally fall into two areas: (1) lack of knowledge, and (2) lack of voluntariness."), quoting Holyfield, $476 \mathrm{~F}$ Supp at 109.

198 See, for example, Ting $v A T \& T, 182 \mathrm{~F}$ Supp 2d 902, 929 (ND Cal 2002) (finding that an agreement "possessed the 'surprise' necessary for a finding of procedural unconscionability").

199 Although "unconscionability" is the doctrinal label most often invoked by courts considering the enforceability of form contract terms, courts sometimes invoke other doctrinal labels as well, such as "reasonable expectations," "public policy," or "contra proferentem." This Article does not separately address each of these doctrines, because they provide little additional assistance in understanding the specific factors courts consider when deciding whether to enforce form terms qua form terms.

The doctrine of "reasonable expectations" and its variation described in Section 211 of the Restatement (Second) of Contracts have been incorporated into unconscionability analysis by most courts and are, therefore, considered in this Part as they relate to procedural unconscionability. See Part IV.A.4.

Courts often inquire as to whether a form contract term is unenforceable because it is contrary to public policy. In many cases in which the term "public policy" is invoked, a form term is at issue but the fact that term is presented to the buyer in a standard form is not crucial. For example, courts will refuse to enforce any term that contravenes public policy as expressed in some legislative action, and it so happens that such terms often are included in form contracts. See, for example, Hawkins v Peart, 2001 UT 94, 37 P3d 1062, 1064, 1066 (2001) (holding that a form contract releasing defendant from liability for future injury to a minor violates public policy because various statutes demonstrate that the legislature has a protective intent toward minors); Armendariz, 6 P3d at 683 (stating that a remedy limitation for statutory claims violates public policy). Courts also have held that form terms that disclaim liability for negligence are unenforceable as violations of public policy where the contract concerns the public interest. See, for example, Tunkl v Regents of University of California, $60 \mathrm{Cal} 2 \mathrm{~d}$ 92, 383 P2d 441 (1963). Although these cases sometimes list whether the term is presented on a standard form among the factors relevant in the analysis, see id at $445-46$, the courts' reasoning suggests it is unlikely that an otherwise-unenforceable term would be saved merely because it was fully dickered. See, for example, Hiett v Lake Barcroft Community Association, 244 Va 191, 418 SE2d 894, 897 (1992) (“"[T]o hold that ... one party [may put others] at the mercy of its own [negligent] misconduct ... can never be lawfully done. Public policy forbids it."), quoting Johnson's Administratrix v Richmond and Danville Railroad, 86 Va 975, 11 SE 829, 829 (1890); Dalury v S-K-I Ltd, 164 Vt 329, 670 A2d 795, 797-98 (1995) (explaining that a public policy analysis of an exculpatory clause turns on whether defendant's business concerned the public interest). Whether a term violates "public policy" in either of these senses is distinct from the issue considered in this Article of whether courts should refuse to enforce form terms because they are form terms.

In some cases, courts invoke the term "public policy" in their evaluation of form terms and then analyze the factors that are usually considered in an unconscionability analysis-most often, whether there was unequal bargaining power. See, for example, Shell Oil Co v Marinello, $63 \mathrm{NJ}$ 402,307 A2d 598,601 (1973) (stating that contracts are void as against public policy when "there is grossly disproportionate bargaining power"); Rozeboom v Northwestern Bell Telephone Co, 358 NW2d 241, 242 (SD 1984) (stating that the enforcement of an adhesive term of a monopolist 


\section{A. Procedural Unconscionability}

\section{The adhesive nature of form contracts.}

In some cases, courts point to the adhesive nature of form contracts $^{201}$ as evidence that the terms therein are "involuntary" and thus procedurally unconscionable..$^{201}$ As previously noted, in contrast to the Platonic ideal of a contract in which all terms are subject to bargaining, form contracts are usually offered on a take-it-or-leave-it basisperhaps the price is negotiable, but often even this is not subject to bargaining. Quite frequently, the buyer lacks access to any employee of the seller who has the authority to alter the terms. ${ }^{212}$ Thus, courts are quite correct when they observe that buyers often have only the two

against a customer with no bargaining power would violate public policy). In these cases, the judicial analysis is essentially identical to an unconscionability analysis, and the relevant factors are already considered in this Part.

Courts also often invoke the doctrine of contra proferentem in the context of form contracts and thus rule that ambiguous terms should be interpreted against the drafting party. See, for example, New Castle County v National Union Fire Insurance Co of Pittsburgh, 243 F3d 744, 750 (3d Cir 2001) (noting that insurance policies are contracts of adhesion, and explaining that because customers have "little to say" about the terms in insurance policies, any ambiguity is construed against the drafting party). Although contra proferentem is employed most commonly in the context of insurance contracts, it is used in other contexts as well. See, for example, In re Parker, 269 BR 522, 530 (D Vt 2001) (residential lease); Yang Ming Marine Transport Corp v Oceanbridge Shipping International, Inc, 48 F Supp 2d 1049, 1057 (CD Cal 1999) (bill of lading); Southern Atlantic Financial Services, Inc v Middleton, 349 SC 77, 562 SE2d 482, 486 (SC App 2002) (mortgage agreement). The doctrine only applies, however, when the term at issue is ambiguous. This Article, in contrast, is concerned primarily with the enforceability of form contract terms that are clear on their face.

200 The dominant definition of an adhesion contract is a contract in which terms are nonnegotiable. Rudbart v North Jersey District Water Supply Commission, 127 NJ 344, 605 A2d 681, 685 (1992) (defining a contract of adhesion as a "standardized printed form" offered on a "takeit-or-leave-it basis"). See also note 4 . Some courts, however, have defined an adhesion contract as one in which the terms are non-negotiable and the buyer cannot obtain the desired goods or services from any other source. See, for example, Steven v Fidelity and Casualty Co of New York, 58 Cal 2d 862, 377 P2d 284, 297 (1962).

201 See, for example, Circuit City Stores, Inc v Adams, 279 F3d 889, 893 (9th Cir 2002) (finding an arbitration clause "procedurally unconscionable because it is a contract of adhesion"); Ting, 182 F Supp 2d at 929 (concluding that case law favors plaintiff's position that a finding that a contract is adhesive is "tantamount to a finding of procedural unconscionability"); Iwen, 977 P2d at 996 (finding "no meaningful choice" on the part of the buyer because the contract was presented on a take-it-or-leave-it basis); Entergy Mississippi Inc, 726 \$2d at 1208 (finding that an indemnity clause was "essentially a contract of adhesion" and was therefore procedurally unconscionable); Stirlen v Supercuts, Inc, 60 Cal Rptr 2d 138, 145-46 (1997) (finding that an employment contract was a contract of adhesion and thus procedurally unconscionable). The majority of courts, however, find that the fact that a contract is adhesive is not alone enough for a finding of procedural unconscionability. See, for example, Dean Witter Reynolds, Inc v Superior Court, 211 Cal App 3d 758, 259 Cal Rptr 789, 796 (1989) ("[W]e are not prepared to hold that [oppression and adhesiveness] are identical.").

202 See Rakoff, 96 Harv L Rev at 1225 (cited in note 4) (noting that the institutional structure of business results in the salesman lacking authority to bargain and that "there may in fact be no one at any level who is willing to bargain"). 
options of adhering to the seller's terms or not purchasing the seller's product. ${ }^{2,3}$

As Part I of this Article illustrates, however, and as many commentators have noted, ${ }^{2 / 4}$ there is nothing about the adhesive nature of a contract itself that suggests the contract is particularly likely to contain inefficient terms. The suggestion by some courts that adhesive contracts are particularly prone to terms that are undesirable for buyers arises from a fundamental misunderstanding about how the market disciplines sellers. If buyers conduct a complete cost-benefit analysis and can shop amongst competing sellers, the market will provide them with efficient product attributes at the lowest possible price. ${ }^{205}$ If buyers conduct a complete cost-benefit analysis and cannot or do not shop, the market should still provide them with efficient product attributes, albeit at a higher price. ${ }^{216}$ The fact that a contract is offered on an adhesive basis does not suggest that its terms are particularly likely to be inefficient and thus bad for buyers as a class.

\section{Unequal bargaining power.}

Courts more often base findings of procedural unconscionability on the adhesive nature of form contracts coupled with perceived inequalities in bargaining power between buyer and seller. ${ }^{2177}$ The implicit claim is that sellers use their relative bargaining strength to force buyers to accept term combinations that make buyers worse off than they would be if bargaining power were more equal between the parties. Unequal bargaining power as defined by courts, however, rarely suggests an unusually high likelihood of inefficient contract terms. With limited exceptions, courts' reliance on this factor demonstrates a mis-

203 See, for example, Cooper v MRM Investment Co, 199 F Supp 2d 771, 778 (MD Tenn 2002) ("Plaintiff had no choice. She either had to accept the job on the terms outlined ... or she had to find another job."); Armendariz, 6 P3d at 690 ("[The arbitration agreement] was imposed on employees as a condition of employment and there was no opportunity to negotiate."); Iwen, 977 P2d at 995 (“[Defendant's] advertising order is a standardized form agreement, the terms of which [plaintiff] was unable to negotiate and for which his only choice was to accept or reject.").

204 See, for example, Kennedy, 41 Md L Rev at 616 (cited in note 15).

205 See Part I.A.

206 See Part I.B.

207 See, for example, Fujimoto $v$ Au, 95 Hawaii 116, 19 P3d 699, 739 (2001); Durdahl v National Safety Associates, Inc, 988 P2d 525, 529 (Wyo 1999) (enforcing agreement because appellants provided no evidence concerning the relative bargaining powers of the parties); Malan Realty Investors, Inc v Harris, 953 SW2d 624, 628 (Mo 1997) (enforcing agreement because there was no evidence defendant was under a bargaining disadvantage); Shell Oil Co, 307 A2d at 601 (declining to enforce contract between Shell Oil and service station, and noting that "where there is grossly disproportionate bargaining power ... courts will not hesitate to declare void as against public policy grossly unfair contractual provisions").

$208 \mathrm{See}$, for example, Williams, 350 F2d at 449-50 (arguing that a party with "little bargaining power" does not give "consent" to terms, and thus "the court should consider whether the terms of the contract are so unfair that enforcement should be witheld"). 
understanding both of the sources and consequences of bargaining power.

a) Monopoly or oligopoly. Courts frequently allege that unequal bargaining power resulting from a seller's market power allows the seller to force onerous contract terms on buyers and thus supports a finding of procedural unconscionability. ${ }^{219}$ It is true that when a buyer can purchase a product only from a single monopolist seller or not at all, the seller enjoys bargaining leverage not available to sellers in competitive markets. If a widget maker is a monopolist, buyers can threaten to exit the market, but they cannot exercise leverage by threatening to buy from another seller.

As Part I.A.2 describes, however, even monopolists have an incentive to offer efficient terms, because by doing so they are able to maximize monopoly profits. ${ }^{210}$ Assuming that most buyers would be willing to pay $\$ 150$ for a high-quality warranty that costs the seller only $\$ 100$ to provide, the monopolist will maximize its income by providing the warranty. Doing so would enable it to raise its monopoly price by $\$ 150$ while increasing its costs by only $\$ 100$. If a monopolist offers an inefficient non-price term, the problem is most likely the non-salience of the term, not the seller's monopoly."

Many markets, of course, are neither fully competitive nor dominated by a single monopolist, but the analysis presented thus far is identical if the market is best characterized as an oligopoly. In the landmark case of Henningsen $v$ Bloomfield Motors, ${ }^{212}$ the court reviewed a form contract for the sale of an automobile that included a

209 See, for example, Andersons, 166 F3d at 324 (finding no procedural unconscionability because the plaintiff "essentially admits that it had at least some alternative buyers"); Entergy, $726 \mathrm{~S} 2 \mathrm{~d}$ at 1208 (finding an indemnification term procedurally unconscionable because of the seller's monopolistic position and refusal to negotiate terms); Rozeboom, 358 NW2d at 242-45 (finding a term unconscionable because the seller was a monopoly and the buyer could obtain the product "from only one source"); Allen v Michigan Bell Telephone Co, 18 Mich App 632, 171 NW2d 689, 693 (1969) (finding an adhesive term procedurally unconscionable because the telephone company was the only service provider).

210 A qualification is in order here. A seller with market power will have an incentive to provide low-quality terms, whether or not efficient, if that seller is prevented by other legal rules from adjusting price. For example, price-regulated utilities, landlords subject to rent-control laws, and employers who pay the minimum wage will have an incentive to increase profits by indiscriminately reducing costs via low-quality terms.

211 This statement, while generally true, will not be true in all cases, because it assumes that buyers who do not value the term in question at more than its cost are randomly distributed amongst the class of buyers, which might not be the case. For example, if all inframarginal buyers would pay more for a warranty than the terms cost, but all marginal buyers would prefer to do without the warranty, it is possible, depending on the precise shape of the demand curve, that the monopolist would choose not to offer the warranty term - even though it would make most of its customers better off - in order to avoid losing the marginal customers who would forgo purchasing its product if the monopolist added the warranty and raised prices to cover the additional cost.

$$
21232 \text { NJ 358, } 161 \text { A2d } 69 \text { (1960). }
$$


warranty disclaimer. The court identified as a procedural concern the fact that all three of the major American automobile manufacturers used the same industry-drafted form contract. ${ }^{213}$ According to the court, this made the parties' bargaining positions "grossly unequal.".1/4 But it is unlikely that this fact caused the parties to contract for an inefficient warranty term. If buyers valued a high-quality warranty more than it cost manufacturers to provide it and buyers priced the warranty term as part of their purchase decision, manufacturers would have had an incentive to abandon the industry form contract in an effort to steal customers from rivals. ${ }^{215}$ It is possible that the benefits of using the same terms as others in the industry overshadowed any possible competitive advantage that one manufacturer could gain by offering a more efficient term. ${ }^{216}$ But if this were the case, why would the oligopolistic group of manufacturers not jointly rewrite the shared form contract term, thus providing a more efficient product and increasing profits? If the low-quality term at issue in Henningsen was in fact inefficient, this was more likely caused by a lack of salience of warranty terms among buyers than by oligopoly conditions.

b) Relative size. Courts sometimes find that a buyer was the victim of unequal bargaining power on the basis of evidence that the seller is a large company whereas the buyer is an individual or a smaller company. ${ }^{217}$ These courts imply that a seller's stronger market

213 Id at 87.

214 Id at 94. See also Ting, 182 F Supp 2 d at 929 (basing a finding of procedural unconscionability in part on the observation that most long-distance carriers provide similar terms).

215 See also American General Finance, Inc v Branch, 793 S2d 738, 748,750 (Ala 2000) (finding the fact that virtually all lenders provide borrowers with the same standard terms to be indicative of "overwhelming bargaining power").

216 For an analysis of how firms in an industry might benefit from the network externalities of using common contract terms, see Marcel Kahan and Michael Klausner, Standardization and Innovation in Corporate Contracting (or "The Economics of Boilerplate"), 83 Va L Rev 713, 73336 (1997); Michael Klausner, Corporations, Corporate Law, and Networks of Contracts, 81 Va L $\operatorname{Rev} 757,761$ (1995). For an analysis of how contracting parties might derive psychological value from using standard terms, see Russell Korobkin, Inertia and Preference in Negotiation: The Psychological Power of Default Rules and Form Terms, 51 Vand L Rev 1583, 1605-26 (1998).

217 See, for example, Arnold v United Companies Lending Corp, 204 W Va 229, 511 SE2d 854,861 (1998) ("The relative positions of the parties, a national corporate lender on one side and elderly, unsophisticated consumers on the other, were 'grossly unequal."'); $A$ \& $M$ Produce Co v FMC Corp, 135 Cal App 3d 473, 186 Cal Rptr 114, 125 (1982) (finding unequal bargaining power and thus procedural unconscionability based on the fact that FMC had tens of millions of dollars in annual sales whereas A \& M only employed five people permanently and fifty seasonally). Of course, other courts have held that relative size of the parties is not a relevant factor. See, for example, Mayflower Transit Co, Inc v Ann Arbor Warehouse Co, 892 F Supp 1134, 1140 (SD Ind 1995) ("Although we concede that the relative sizes of Mayflower and its local agents are unequal, that disparity in size does not necessarily translate into a gross disparity in bargaining power."). 
position (although not necessarily a monopolistic one) relative to a buyer can enable the former to impose one-sided terms on the latter."

Size disparities between trading partners are even less likely than the presence of monopoly power to signal the presence of inefficient contract terms. The strength of a party's relative bargaining position is defined not by its size but by the availability of other contracting options. ${ }^{219}$ The maximum amount that a buyer will pay for a product (including the contract terms that accompany it) depends on the relative value he places on that product compared to substitute products. ${ }^{220}$ The minimum amount the seller will accept for a product depends on what other buyers will pay for it, or for other products the seller might produce with the same resources. ${ }^{221}$ If there are many potential buyers bidding for the complete inventory of automobile dealers' new cars, for example, those dealers will have a strong bargaining position relative to car buyers and be able to extract relatively higher prices, measured either in cash or in favorable contract terms. But if few buyers feel a need to purchase a new car and dealers have large inventories, buyers will be able to extract more favorable prices and/or terms from the sellers. In other words, size is beside the point when it comes to evaluating bargaining power.

There might be a correlation between the size of a party and bargaining power, however, because large companies on average have more and better alternatives if no contract is formed than do small companies or individuals. And large companies, like monopolists, no doubt will attempt to take advantage of the fact that they have better outside options than their contracting partners. This is a difficult problem to remedy, however, as there is no accepted general theory about how the gains-in-trade that a transaction creates should be divided between the parties ${ }^{222}$-in rare cases is it divided evenly. More importantly, even if a large seller enjoys bargaining power relative to its customers, as in the case of monopoly, there is no reason to think that this fact alone increases the likelihood that the contract will include inefficient terms. The seller is far more likely to use its superior leverage to

218 See Friedrich Kessler, Contracts of Adhesion: Some Thoughts about Freedom of Contract, 43 Colum L Rev 629,640 (1943) (suggesting that form contracts could enable "powerful industrial and commercial overlords . . to impose a new feudal order . . on a vast host of vassals").

219 See Russell Korobkin, A Positive Theory of Legal Negotiation, 88 Georgetown L J 1789, 1796-97 (2000); Roger Fisher and William Ury, Getting to Yes: Negotiating Agreement without Giving In 102 (Houghton Mifflin 2d ed 1991) (Bruce Patton, ed) (arguing that "the relative negotiating power of two parties depends primarily upon how attractive to each is the option of not reaching agreement").

220 Korobkin, 88 Georgetown L J at 1794-97 (cited in note 219).

221 Id.

222 See id at $1816-29$. 
charge a higher price for efficient terms and thus capture a larger percentage of the cooperative surplus that the transaction creates. ${ }^{223}$ Thus, it is unlikely that the existence of a size disparity between contracting parties is even a weak predictor of the presence of inefficient contract terms.

c) Importance of the seller's product. Just as courts sometimes assert that sellers have bargaining power because of their size or overall financial resources, they sometimes declare a bargaining advantage for sellers when the product being offered is particularly important to buyers. ${ }^{224}$ For example, in Armendariz v Foundation Health Psychcare Services, Inc, ${ }^{225}$ the California Supreme Court recently invalidated an arbitration clause in an employment contract. The court noted that the pressure to accept the clause for "all but the most sought-after employees may be particularly acute, for the arbitration agreement stands between the employee and necessary employment, and few employees are in a position to refuse a job because of an arbitration agreement. 2026

This reasoning suffers from the same flaws as does the claim that large corporations enjoy superior bargaining power relative to smaller companies or individuals. As important as employment might be, no particular job is "necessary" for an individual as long as there is competition among employers. In a competitive employment market, if arbitration clauses are more costly than valuable to a given job-seeker, that job-seeker should be able to locate an alternative employment opportunity with a more desirable combination of terms (that is, no arbitration clause and a lower salary). Several courts, in upholding arbitration clauses in employment contracts, have noted just this fact.

If arbitration clauses are undesirable to employees on balance and salient, even an employer who enjoys bargaining power should eliminate the arbitration clause and offer a lower salary. The salary floor provided by minimum wage laws may contradict the general

223 See Part IV.A.2.a.

224 See, for example, Seigneur v National Fitness Institute, Inc, 132 Md App 271, 752 A2d 631, $638(2000)$ (stating that "[t]o possess a decisive bargaining advantage over a customer, the service offered must usually be deemed essential in nature," and providing as examples of such essential services schools, housing, hospitals, and public utilities).

22524 Cal 4th 83, 6 P3d 669 (2000).

226 Id at 690 . See also Adams, 279 F3d at 893 (noting that employees are not in a position to modify the terms of the contract); Cooper, $199 \mathrm{~F}$ Supp $2 \mathrm{~d}$ at 779 (finding that, in the employment context, an employee "simply has no choice" but to accept adhesive terms).

227 See, for example, Morrison v Circuit City Stores, Inc, 70 F Supp 2d 815, 821-22 (SD Ohio 1999) ("[S]everal other electronic retailers exist in the Cincinnati area, and ... Plaintiff could have applied for positions with these retailers."); Stadtlander v Ryan's Family Steakhouses, Inc, 794 S2d 881, 889 (La App 2001) ("[W]e conclude that the worker, who could have found a similar position elsewhere, could have avoided the arbitration agreement had she objected to it by simply choosing to work elsewhere."). 
analysis in a particular case and encourage employers to provide inefficient terms to minimum-wage employees as a second-best method of exploiting bargaining power, ${ }^{22 x}$ but courts do not limit their holdings to minimum-wage employees.

d) Situation-specific monopoly. There is one type of situation in which unequal bargaining power is particularly likely to signal the presence of inefficient terms: when, after agreeing on a price, sellers establish a situation-specific monopoly and then provide nonnegotiable form terms to buyers. ${ }^{229}$ In the typical situation, a seller operating in a competitive environment publicizes a product's price and/or some other visible features, which encourages a potential buyer to make an investment in time or money in preparing to purchase the product. Then, after the buyer's investment of time or money has been made, the seller presents a set of adhesive form terms that the buyer must sign or forfeit his initial investment.

As an example, consider the facts of Sun Trust Bank v Sun International Hotels, $L t d^{220}$ A traveler from Florida made an advanced reservation at the defendant's hotel over the internet. ${ }^{221}$ When she arrived at the hotel in the Bahamas, she was asked to sign a form contract that included a forum selection clause, which specified that any litigation between the parties must take place in the Bahamas. ${ }^{2.2}$ The district court invalidated the forum selection clause, not because it was contained in a pre-printed form or because it was adhesive, but because of when it was presented. As the court observed, "while [the hotel's] guests may be afforded sufficient opportunity to read the forum selection clause, they have no objectively reasonable opportunity to consider and reject it. ${ }^{2233}$

The court's concern with the forum selection clause in Sun Trust Bank is justified because, in that context, buyers' ability to shop amongst hotels - or even to determine whether staying at the hotel would maximize utility compared to not traveling at all-was compromised. Although the defendant's hotel operates in a competitive

22x Minimum wage laws prevent employers from reducing salary to low-wage employees to compensate for high-quality terms. In such a case, however, the source of the potential for inefficient terms is the floor on the price of labor, not the importance of a job to the employee.

229 See, for example, Sun Trust Bank $v$ Sun International Hotels, Ltd, 184 F Supp 2d 1246, 1252 (SD Fla 2001) (discussing a non-negotiable forum selection clause presented to buyer upon arrival at overseas hotel); Shell Oil, $307 \mathrm{~A} 2 \mathrm{~d}$ at 601 (noting that when service station dealer has invested in building his business and clientele he has little choice but to "sign on the dotted line" when it is time to renew his lease with an oil company); Powertel, 743 S2d at 575 (observing that a cellular phone customer presented with an arbitration term after initiating service would lose her investment with the provider were she to cancel her service).

230) 184 F Supp 2d 1246 (SD Fla 2001).

231 Id at 1252 .

232 Id.

233 Id at 1261. 
market, it becomes a monopolist vis-à-vis an individual buyer after the buyer makes a reservation and invests in traveling to the hotel's location. At this point, shopping for a different hotel is theoretically possible, but doing so becomes far more expensive than shopping amongst hotels prior to travel. This allows the hotel to charge a higher effective price at the counter than it could have charged when the plaintiff made her reservation.

Unlike a traditional monopolist, however, the hotel cannot provide efficient terms and raise the price more than the cost of those terms, because it already pledged a specific nominal price at the time when it was in competition with other sellers. The effective price can be increased only via the terms that have not yet been negotiatedthose in the form contract. In this situation, the seller's incentive is to provide low-quality terms, whether or not such terms are efficient. Adhesive terms that are extremely onerous to buyers might cause some buyers to suffer the transaction costs associated with switching sellers to avoid those terms. But for terms that are only mildly onerous to buyers, the rational response of the buyer is to sign the form and accept the terms.

Ironically, although situation-specific monopolies created after parties agree on a price are the only situations in which "unequal bargaining power" is particularly likely to signal the presence of inefficient terms, courts usually uphold the form terms in such contracts without even inquiring into the terms' substantive content. In the landmark cases of Pro CD v Zeidenberg ${ }^{2.4}$ and Hill $v$ Gateway, ${ }^{2,5}$ the Seventh Circuit upheld form terms included inside the packaging of computer software and hardware respectively on the grounds that the buyers, who could not access the terms until after purchasing the merchandise, could have returned it to the sellers if they did not wish to accept the adhesive terms. ${ }^{2.36}$ After the purchase, however, the buyers had already invested in the particular products, and returning them would have required expending additional time and effort. Although the sellers were not monopolists at the time of sale, they enjoyed a situation-specific monopoly vis-à-vis customers who had already purchased their merchandise. Of course, they could not have taken advantage of this by charging a higher price, because the price term had already been agreed upon (and paid). Unable to renegotiate price, the sellers had an incentive to try to capture benefits of their monopoly position by providing low-quality terms.

23486 F3d 1447 (7th Cir 1996).

235105 F3d 1147 (7th Cir 1997).

236 Pro CD, 86 F3d at 1452; Hill, 105 F3d at 1150 . See also Brower, 676 NYS2d at 573-74 (declining to find an arbitration clause included with a mail-ordered computer procedurally unconscionable). 


\section{Lack of sophistication and poverty.}

Courts also sometimes find involuntariness sufficient to support a finding of procedural unconscionability when the buyer is poor, uneducated, or unsophisticated relative to the seller. ${ }^{237}$ A finding of lack of sophistication often rests on the buyer's disadvantaged educational background or lack of experience in the type of transaction at hand and acts, in a sense, as a finding of transactional incompetence by the court. $^{2.38}$ The implicit conclusion is that the unsophisticated buyer is bullied by the seller into accepting terms that leave him worse off than he otherwise would be. ${ }^{239} \mathrm{~A}$ buyer's poverty can lead courts to the same conclusion: that his lack of sophistication caused him to accept an undesirable term. ${ }^{241}$

There are at least three reasons why, in theory, a seller might offer inefficient terms to unsophisticated buyers. First, unsophisticated buyers might be incapable of determining what value they would experience from a certain term. ${ }^{241}$ If buyers cannot determine whether a term is valuable or not, they cannot price its content as part of their purchase decision, thus giving sellers an incentive to provide a low-quality term. This argument seems spurious on its face, as there is no obvious reason to believe that the poor or uneducated are unable to identify what product attributes are subjectively valuable or not valuable to them.

Second, poverty might be correlated with the availability of few contracting options and thus little bargaining power. ${ }^{242}$ For example, a

237 See, for example, John Deere Leasing, 636 F Supp at 1574 (finding procedural unconscionability in part because "there was clearly a 'disparity in sophistication' between John Deere Leasing and the defendant, a farmer"); Leonard v Terminix Intern Co, 2002 Ala LEXIS 316, *19 (declining to enforce an arbitration agreement in part because plaintiffs were neither sophisticated nor wealthy); Denlinger, Inc v Dendler, 415 Pa Super 164, 608 A2d 1061, 1066 (1992) (enforcing a term because plaintiff was a sophisticated businessman); Kugler v Romain, 58 NJ 522 , 279 A2d 640, 652 (1971) ("The need for application of the [unconscionability] standard is most acute when the professional seller is seeking the trade of those most subject to exploitation - the uneducated, the inexperienced and the people of low incomes.").

238 See, for example, Weaver, 276 NE2d at 145 (finding that plaintiff, who had left high school after one and one-half years, "was not one who should be expected to ... understand the meaning of technical terms").

239 See Jones v Star Credit, 59 Misc 2d 189, 298 NYS2d 264, 265 (NY Sup Ct 1969) (registering concern for the protection of the "uneducated and often illiterate individual ... against overreaching by the small but hardy breed of merchants who would prey on them").

240 See, for example, Williams, $350 \mathrm{~F} 2 \mathrm{~d}$ at 448 (noting that the seller knew the buyer had to support seven children on government assistance); Jones, 298 NYS2d at 264 (noting that buyers were welfare recipients).

241 See, for example, Schwartz, 63 Va L Rev at 1076 (cited in note 31) ("It is now commonly assumed that many people, in particular the poor, cannot competently maximize their utility.").

242 See Leonard, 2002 Ala LEXIS 316 at *22 (noting that plaintiffs, who were not "sophisticated or wealthy consumers with equal bargaining power" would have had to pay at least $\$ 1,000$ in added costs to turn down the seller's adhesive contract and switch to a competitor). 
buyer without private transportation-or, in today's economy, an internet connection - might accept less-favorable terms from a seller than someone without this disadvantage because shopping alternative suppliers is more costly. ${ }^{243}$ Another way of putting this is to say that if a buyer is too poor to shop widely, a nearby seller enjoys something akin to monopoly power in that particular circumstance.

Even if true, however, this does not make poverty an indicium of inefficient contract terms, because monopolists are best off taking advantage of their position to raise price rather than impose inefficiently low quality. ${ }^{24}$ Of course, the poor are particularly likely to be price sensitive, and might prefer low-quality terms to higher prices. But, where this is the case, low-quality terms are efficient by definition, which means that courts that refuse to enforce those terms and thus force sellers to substitute higher-quality terms combined with higher prices would make buyers worse off.

Third, unsophisticated buyers might have particular difficulty pricing a term as part of a complex purchase decision involving many product attributes due to factors such as low levels of education ${ }^{245}$ or literacy. ${ }^{246}$ An extreme example illustrates the point: In Frostifresh Corp v Reynoso, ${ }^{247}$ a door-to-door appliance seller convinced a buyer who spoke only Spanish to sign a contract with form terms written in English. ${ }^{248}$ Presumably, the English terms were non-salient to the buyer, whereas the terms might have been salient to an English speaker.

As long as sellers offer the same form terms to all buyers, the fact that a particular buyer is unsophisticated should not affect the incentives of sellers. A widespread lack of education or sophistication among a seller's customer base, however, might make terms in a form contract more likely to be non-salient than if those customers were

243 In two studies of new car sales practices, Ian Ayres found that Chicago-area car dealers offered African-Americans prices that were, on average, higher than those they offered to whites. Although Ayres believes part of the discrepancy may be explained by simple racism, he thinks that part of the explanation may also be that sellers might use race as a signal of wealth and, thus, of the ability to shop around for a better price. See Ian Ayres, Fair Driving: Gender and Race Discrimination in Retail Car Negotiations, 104 Harv L Rev 817, 845 (1991); Ian Ayres, Further Evidence of Discrimination in New Car Negotiations and Estimates of Its Cause, 94 Mich L Rev $109,138-40$ (1995).

244 See Part I.A.2.

245 See, for example, Williams, 350 F2d at 449 (asking whether "each party to the contract, considering his obvious education or lack of it, had a reasonable opportunity to understand the terms of the contract").

246 See, for example, Johnson v Mobil Oil Corp, 415 F Supp 264, 268-69 (ED Mich 1976) (refusing to enforce a form term where the buyer was "practically illiterate" and thus did not give his "voluntary, knowing assent").

24752 Misc 2d 26, 274 NYS2d 757 (D Ct NY 1966), revd, 54 Misc 2d 119, 281 NYS2d 964 (NY App Term 1967).

248274 NYS2d at 758. 
better educated and more sophisticated, thus increasing the likelihood that sellers will provide inefficiently low-quality terms. And there will often be a positive correlation between the level of sophistication of one customer of a particular seller and other customers of that seller-one suspects, for example, that many of the customers of the door-to-door Frostifresh salesman did not speak English. Thus, the lack of sophistication of a particular buyer might indicate a higherthan-average likelihood that inefficiently low-quality form terms are present. But even in the most optimistic case, the logic is extremely attenuated. The fundamental problem that makes inefficient terms possible is not the relative lack of sophistication of buyers, but that some terms are non-salient.

\section{Unfair surprise/lack of notice.}

Some courts have ruled that form terms unknown to the buyer are unenforceable if the buyer is ignorant of even the existence of terms and this ignorance is reasonable. The doctrinal explanation is that contract terms must be "reasonably communicated" to be valid and that this requirement is not met when the buyer has no reason to know of the presence of such terms. ${ }^{24 y}$ The usual situation involves a document meant to serve two purposes, the first functional and the second as a means of communicating contract terms, where the latter purpose is not obvious to the buyer. ${ }^{2 \mathrm{2}}$ In the standard casebook example, a bailor gives a bailee a claim check that the bailee must present to reclaim his property. ${ }^{2.1}$ Unknown to the bailor, the claim check contains, on its reverse side, language that purports to limit the bailee's liability for the loss of or damage to the property. ${ }^{2.2}$

Although claim-check cases might seem somewhat quaint in the twenty-first century, courts employ similar reasoning in finding unenforceable contract terms printed on the backs of tickets for transport or admission when the seller does not warn the buyer that terms can be found there. ${ }^{2.3} \mathrm{~A}$ uniquely modern analog of the claim

249 See Silvestri v Italia Societa Per Azioni Di Navigazione, 388 F2d 11 (2d Cir 1968) (establishing that terms must be "reasonably communicated" to purchasers).

250 See, for example, Shankles v Costa Armatori, SPA, 722 F2d 861, 865 (1st Cir 1983) (analyzing whether the outside of a ticket conspicuously warned purchasers that terms were enclosed).

251 See Klar v H\&M Parcel Room, Inc, 270 AD 538, 61 NYS2d 285 (1946). See also McAshan v Cavitt, 149 Tex 147, 229 SW2d 1016 (1950); Healy v New York Central and Hudson River Railroad, Co, 153 AD 516, 138 NY 287 (1912).

252 See, for example, Klar, 61 NYS2d at 289 ("In the mind of the bailor the little piece of cardboard ... did not arise to the dignity of a contract.").

253 See, for example, Ward v Cross Sound Ferry, 273 F3d 520 (2d Cir 2001) (concluding that a term on a ferry ticket is unenforceable when a passenger purchased the ticket only minutes before boarding the boat and was then required to hand the entire ticket back to the carrier's 
check is a "browse-wrap" license, in which a computerized document (often a web page) provides instructions to the user on how to download the seller's software, and secondarily informs the user of the existence of contract terms (often located in another cyberspace location). ${ }^{254}$ At least two courts have found software sellers' terms unenforceable due to lack of assent on the buyers' part when a reasonable buyer could use the seller's product without noticing that it contained contract terms.

The more difficult problem for courts has been how to treat circumstances in which a buyer knows that the seller has presented him with a set of form terms but fails to read the terms. The traditional rule is that the buyer has a duty to read any form contract that he signs and, therefore, cannot later claim that he was ignorant of its contents. This "duty to read" rule is consistent with the general principle that contracts are interpreted based on the parties' objective manifestations of intent rather than their actual, subjective intent, ${ }^{257}$ and it is an understandable judicial response to what otherwise could be an unmanageable moral hazard problem. If buyers could preserve the right to challenge ex post any contract term of which they were unaware ex ante, they would have a perverse incentive to avoid learning the content of all terms.

The problem with the duty-to-read approach is that it trades a moral hazard problem for the type of lemons problem that arises

agent); O'Brien v Okemo Mountain, Inc, 17 F Supp 2d 98 (D Conn 1998) (finding that a term on the back of a ski lift ticket is unenforceable where the front of the ticket did not instruct the buyer to read the back).

254 See, for example, Kaustuv M. Das, Forum Selection Clauses in Consumer Clickwrap and Browsewrap Agreements and the "Reasonably Communicated" Test, 77 Wash L Rev 481, 497-500 (2002) (explaining the characteristics of "browsewrap" agreements).

255 Specht v Netscape Communication Corp, 306 F3d 17 (2d Cir 2002); Ticketmaster Corp v Tickets. Com, Inc, 2000 US Dist LEXIS 4553, *8 (CD Cal). Courts routinely find assent to "clickwrap" contracts, in which software buyers must click on a box on the computer screen indicating that they assent to the seller's terms before being able to use the software. See Das, 77 Wash L Rev at 500 \& 179 (cited in note 254) (discussing and listing cases that have addressed the question of forum selection clauses in clickwrap agreements).

256 See, for example, Upton v Tribilcock, 91 US 45, 50 (1875):

It will not do for a man to enter into a contract, and, when called upon to respond to its obligations, to say that he did not read it when he signed it, or did not know what it contained. If this were permitted, contracts would not be worth the paper on which they are written. But such is not the law. A contractor must stand by the words of his contract; and, if he will not read what he signs, he alone is responsible for his omission.

The rule applies even for illiterate buyers. See, for example, Johnnie's Homes, Inc v Holt, 790 S2d 956, 960 (Ala 2001); Secoulsky v Oceanic Steam Navigation Co, 223 Mass 465, 112 NE 151, 151 (1916).

257 See generally Hotchkiss v National City Bank, 200 F 287, 293 (SD NY 1911) (Hand) ("A contract has, strictly speaking, nothing to do with the personal, or individual intent of the parties, [but] is an obligation attached by the mere force of law to certain acts."); Oliver Wendell Holmes, The Common Law 309 (Little, Brown 1881). 
whenever a term is non-salient. ${ }^{2.8}$ To the extent buyers do not read form terms notwithstanding the duty to read, either because the costs of reading terms exceeds the expected benefits or the costs of pricing terms exceeds the expected benefits, those terms will necessarily be non-salient. This in turn creates an incentive for sellers to make the terms low quality, whether or not low-quality terms are efficient.

Section 211 of the Restatement (Second) of Contracts attempts to solve this problem. It provides that a buyer's lack of actual knowledge of the content of a form's terms can indicate a lack of assent to the contract as a whole, and thus serve as a defense to contract formation, but only if the offending term is so unexpected and odious that the buyer would have refused to sign the contract had he known of the term and the seller "has reason to believe" the buyer would so react. ${ }^{2.9}$ The Restatement test can help courts to identify terms likely to be inefficient, but if the doctrine's goal is either to ensure social efficiency or protect buyers as a class, the test is both under- and overinclusive. The approach is underinclusive because it protects buyers only from the most outrageously inefficient of terms. If a low-quality term would save the seller less in production costs than buyers would be willing to pay for a high-quality term, the low-quality term will be both inefficient and reduce consumer surplus, even in the case of inframarginal buyers who nonetheless would choose to sign the contract. ${ }^{200}$ The approach is potentially overinclusive because it focuses on individual buyers, rather than buyers as a class. Thus, in theory, a court could invalidate a term if it is grossly inefficient for a single buyer, given that buyer's preferences and the seller's costs, even if the term is efficient for every other buyer and thus justified overall on a costbenefit basis.

The "reasonable expectations" doctrine, ${ }^{261}$ which permits courts to invalidate form terms that defeat the expectations of reasonable consumers, avoids the under- and overinclusiveness problems of the Restatement test, but it has substantial shortcomings of its own. First, it begs the question of whether it is ever "reasonable" not to have actual

258 Compare Akerlof, 84 Q J Econ at 488-90 (cited in note 126).

259 Restatement (Second) of Contracts $\$ 211(3)$. The Restatement rule reflects the belief of Karl Llewellyn that assent to a contract should be understood as specific assent to negotiated terms and to form terms that are not unreasonable. See Rakoff, 96 Harv L Rev at 1198-1200 (cited in note 4 ).

$26 x)$ In a competitive market in which all buyers value form terms identically, any inefficient term should cause a knowing buyer to refuse to sign the contract, because some other seller could be expected to provide a preferable combination of terms and price. In the case of a monopolist, however, it could be the case that providing an unknown inefficient term would enable the seller to maximize profits.

261 See generally Robert E. Keeton, Insurance Law Rights at Variance with Policy Provisions, 83 Harv L Rev 961 (1970). 
knowledge of form terms - a question on which jurists have disagreed. ${ }^{262}$ Second, if reasonable expectations are defined by prevailing custom, as some courts have claimed, ${ }^{263}$ the doctrine could entrench and perpetuate inefficient low-quality terms that become commonplace because they are non-salient to most buyers.

In any event, the Restatement test and the reasonable expectations doctrine appear to have been almost completely forgotten by courts, at least outside of the realm of insurance contracts. ${ }^{2 \pi t} \mathrm{The}$ clear modern trend is for courts instead to consider a buyer's "surprise" with the content of a term as a possible basis for finding procedural unconscionability.

In their procedural unconscionability analysis, courts seem to have attempted to split the difference between the moral hazard problem (which would arise if buyers' ignorance were permitted to work to their advantage) and the lemons problem (which would arise if sellers could enforce terms unknown to buyers) by excusing buyers for their ignorance only when terms are not featured prominently on preprinted forms. Consequently, buyers are rarely if ever successful when challenging form terms that are in bold type, ${ }^{266}$ capital letters, ${ }^{267}$ set off

262 Compare the majority opinion and dissent in Wheeler v St. Joseph Hospital, 63 Cal App 3d 345, 133 Cal Rptr 775 (1976). In that case, the majority struck an arbitration clause as beyond the reasonable expectations of an ordinary person when a contract was signed but not read by a hospital patient. Id at 786 . The dissent complained that the arbitration clause was visible and readable. Id at 797 (Gardner dissenting).

263 See, for example, Sparks $v$ St. Paul Insurance Co, 100 NJ 325, 495 A2d 406, 414 (1985) (finding that terms in insurance policies must be consistent with "commercially reasonable standards" to be enforceable).

264 James J. White reports that as of 1997 only forty-three published judicial opinions had interpreted Section 211(3) of the Restatement, twenty-five of those were penned by Arizona courts, and most of those dealt with insurance coverage disputes. James J. White, Form Contracts under Revised Article 2, 75 Wash U L Q 315, 324-25 (1997). A handful of cases, mostly from Arizona, have applied Restatement $\S 211$ outside of the insurance coverage context. See, for example, Broemmer v Abortion Services of Phoenix Ltd, 173 Ariz 148, 840 P2d 1013 (1992) (applying $\S$ 211 to an arbitration clause in an abortion contract). Non-insurance disputes decided on the basis of the reasonable expectations doctrine are similarly rare in recent years, although they appear occasionally. See, for example, Kloss v Edward D. Jones and Co, 310 Mont 123,54 P3d 1,7-8 (2002) (finding that because the arbitration clause in a brokerage contract conflicted with the customer's reasonable expectations, unconscionability analysis was not necessary). California courts routinely proclaim that, to be enforceable, contract terms cannot be unconscionable or conflict with buyers' reasonable expectations, but all recent cases that state this rule go on to analyze the facts of the case under the unconscionability rubric alone. See, for example, Armendariz, 6 P3d at 689.

265 See, for example, Ting, 182 F Supp 2d at 929-30 (finding surprise where typical customer would not expect new contract terms in a mailing); Villa Milano Homeowners Association v II Davorge, 84 Cal App 4th 819, 102 Cal Rptr 2d 1, 7 (2001) (finding surprise where the term appeared on page sixty-seven of a seventy-page document); Kinney $v$ United Healthcare Services, Inc, 70 Cal App 4th 1322, 83 Cal Rptr 2d 348, 353 (1999) (finding surprise where, inter alia, an employee had not had the opportunity to read terms in the employee handbook).

266 See, for example, Bernstein v GTE Directories Corp, 827 F2d 480, 482 (9th Cir 1987); Parkerson v Smith, 817 S2d 529, 543 (Miss 2002). 
with a different color type face (usually red), ${ }^{2 n t}$ or alluded to on the first page of the contract ${ }^{264}$-at least on the basis that they were unfairly surprised by or did not assent to the term in question. On the other hand, buyers have successfully challenged terms printed in microscopic type, ${ }^{271}$ written in language confusing to laypersons, ${ }^{271}$ hidden deep within a long series of form terms (especially if buyers are given insufficient time to read the contract carefully), ${ }^{272}$ or presented with insufficient notice that the document contained contract terms. ${ }^{273}$

The salience of product attributes depends in part on whether they attract attention, and whether terms attract attention depends in part upon their readability. By classifying terms that are difficult to read as procedurally unconscionable, courts undoubtedly identify some non-salient terms for further substantive review. But the doctrine is substantially underinclusive, because it focuses on one symp-

267 See, for example, Parkerson, 817 S2d at 542-43 (finding no unconscionablility where the clause was conspicuous and in capital letters); M.A. Mortenson Inc v Timberline Software Corp, 140 Wash 2d 568, $998 \mathrm{P} 2 \mathrm{~d} 305,315$ (2000) (noting that the terms were not "hidden in a maze of fine print" but were rather in capital letters); Wilk Paving, Inc v Southworth-Milton, Inc, $162 \mathrm{Vt}$ $552,649 \mathrm{~A} 2 \mathrm{~d} 778,783$ (1994) (noting that the front page of the contract included in large capital letters an advisory that additional terms were on the back side).

26x See, for example, Transamerica Oil Corp v Lynes, Inc, 723 F2d 758, 764 (10th Cir 1983) (noting that terms were in red print).

261) See, for example, Effron v Sun Line Cruises, 67 F3d 7 (2d Cir 1995) (enforcing a term where the front of a cruise ship ticket advised the buyer, "IMPORTANT NOTICE-READ BEFORE ACCEPTING"); Parkerson, 817 \$2d at 543 (discussing an arbitration agreement on a separate document that the buyer signed); Lake Ridge Academy v Carney, 66 Ohio St 3d 376,613 NE2d 183, 189 (1993) (noting that the challenged term appeared on the front of a one-page contract).

270 See, for example, Blubaugh,636 F Supp at 1574 (noting that the term in question was in "minute print ... and was in such light grey type as to be illegible"); East Ford, Inc $v$ Taylor, 826 S2d 709, 716-17 (Miss 2002) (noting that the arbitration clause was printed in less than one-third the size of other terms), cert denied, 123 S Ct 1302 (2003): Philadelphia Indemnity Insurance Co v Barerra, 200 Ariz 9, 21 P3d 395, 402 (2000); McCarlhy Well Co v St. Peter Creamery, Inc, 410 NW2d 312,316 (Minn 1987) (describing the text of the contract as "impenetrable").

271 See, for example, Blubaugh, 636 F Supp at 1574 (noting that the contract was written in "legalistic language that a party with no training in law or finance could not possibly decipher"); Holyfield, $476 \mathrm{~F}$ Supp at 111 (noting that the terms of a lease were not explained to defendants); Kinney, 83 Cal Rptr $2 \mathrm{~d}$ at 353 (finding that the arbitration clause "language ... is so extensive as to render it difficult for a lay person to read and understand").

272 See, for example, Villa Milano Homeowners Association, 102 Cal Rptr 2d at 7 (noting that because contract terms "are 70 pages long and the arbitration clause appears on pages 67 to $68[$.$] . . . it is unlikely the arbitration clause popped right out to the purchaser's attention");$ Kinney, $83 \mathrm{Cal}$ Rptr $2 \mathrm{~d}$ at 353 (noting that an arbitration clause was included by the employer in a "large three-ring binder" and that the employee was "pressured to sign the [contract] that same day").

27.3 See, for example, Ting, 182 F Supp 2d at 912-13 (finding that AT\&T's contract modification mailed to customers in an envelope containing the label "ATTENTION: Important Information concerning your AT\&T service enclosed" and beginning with the phrase "[p]lease be assured that your AT\&T service or billing will not change ... there's nothing you need to do" would encourage customers to throw away the term sheet rather than read it).

274 See Part II.C. 
tom of the problem rather than on the problem itself. Whereas the doctrine is concerned with whether terms are difficult for buyers to read, the larger problem is that they may be non-salient to buyers whether or not they are read. If a term is non-salient for buyers, sellers will have the incentive to imbue it with low-quality content whether or not this is efficient, irrespective of whether the term is easily readable or even customarily read by buyers. The doctrine is also potentially overinclusive. If a particular term is salient for buyers, buyers can inquire into the content of that term before making their purchase decision, even if the term is in small print, buried in long paragraphs of legalese, or otherwise difficult to discern in the form text.

\section{B. Substantive Unconscionability}

As noted above, most courts will refuse to enforce a form contract term if it has elements of both procedural and substantive unconscionability. ${ }^{2.5}$ The types of facts courts have found to violate the procedural aspect of the test are relatively clear, even if some seem irrelevant to the purpose of the inquiry and others, while not irrelevant, are poorly tailored to the fundamental problem of non-salience. What precisely constitutes substantive unconscionability in the eyes of jurists defies clear description, however. Courts often state that a substantively unconscionable term is one that is "overly harsh" or "onesided, ${ }^{, 276}$ is "so one-sided as to be oppressive,", is "unreasonably favorable to the drafter,", formly decline to offer any formulation of how to determine whether this standard is met. ${ }^{20}$

When finding a term substantively unconscionable, courts nearly always focus their attention entirely on explaining why the term is extremely beneficial to sellers and/or detrimental to buyers. In so doing, they generally fail to consider offsetting benefits to buyers in the form of lower prices. Even more importantly, courts usually fail to consider that if the benefits of a term to sellers exceed the costs to buyers, the resulting package of product attributes, including price, will be more desirable for buyers as a class than if the term in question were mandated to be high quality. In other words, the glaring flaw in substantive

275 See note 196 and accompanying text.

276 See, for example, Armendariz, 6 P3d at 690.

277 See, for example, Rosenberg, $170 \mathrm{~F} 3 \mathrm{~d}$ at 17.

278 See, for example, Harris, 183 F3d at 181.

279 See, for example, Ferguson v Countrywide Credit, Inc, 298 F3d 778, 784-85 (9th Cir 2002); Ting, 182 F Supp 2d at 928.

280 See, for example, Ex Parte Foster, 758 S2d 516, 520 n 4 (Ala 1999) (noting that, because there is no "explicit standard" for unconscionability determinations, "each case must be decided on its own facts"). 
unconscionability jurisprudence is that courts focus on the utility of the challenged low-quality term to the litigating buyer ex post, rather than on the utility of the entire contract to buyers ex ante compared to a counterfactual contract in which the challenged term was high quality and other terms (including price) were adjusted in light of this. ${ }^{2 \times 1}$

In recent years, a large plurality, if not a majority, of published judicial opinions concerning the enforceability of terms in form contracts have concerned arbitration clauses, ${ }^{222}$ in which the form contract requires that any legal claim of the buyer's arising from the contract must be pursued through private arbitration rather than public adjudication. Thus, arbitration clause jurisprudence is a good source of insight into the unconscionability doctrine..$^{203}$ In recent years, most courts (but not all ${ }^{234}$ ) have upheld the enforceability of arbitration clauses generally, ${ }^{2 \mathrm{xs}}$ but many have struck down such clauses when the specific arbitration clause at issue appears preferential to the seller: for example, if the clause requires the buyer to arbitrate but allows the seller to litigate some or all of its claims, ${ }^{246}$ if the clause limits the types of dam-

281 The official comments to UCC $\$ 2-302$ do provide that unconscionability should be judged based on the circumstances at the time the contract was made, see UCC $\$ 2-302$ comment 1 , but explicit judicial consideration of the benefits of terms to buyers ex ante are unusual.

282 A Westlaw search for HE((CONTRACT W/2 ADHESION) "FORM CONTRACT") and DA(AFT 12/31/1998), conducted in June 2002, using both "all state" and "all fed" databases, returned ninety-seven cases dealing with unconscionability, fifty-two of which concerned arbitration provisions.

283 The United States Supreme Court has held that courts may not treat arbitration clauses differently than other contract terms, but they may consider challenges to arbitration clauses based on general contract law defenses such as unconscionability, fraud, or duress. See Doctor's Associates, Inc v Casarotto, 517 US 681, 687 (1996).

284 Sec, for example, Cooper, $199 \mathrm{~F}$ Supp 2d 771 (invalidating a standard arbitration clause as unconscionable).

285 See, for example, Doctor's Associates, 517 US 681; Munoz v Green Tree Financial Corp, 343 SC 531, 542 SE2d 360 (2001); Southern Energy Homes, Inc v Gary, 774 S2d 521 (Ala 2000); Kindred v Second Judicial Court, 116 Nev 405, 996 P2d 903 (2000); In re Oakwood Mobile Homes, Inc, 987 SW2d 571 (Tex 1999); In re H.E. Butt Grocery, 17 SW3d 360 (Tex App 2000 ).

286 See, for example, Ferguson, 298 F3d at 785 (stating that an arbitration clause that tends to exempt the claims drafter from arbitration is most likely to be unconscionable); Ticknor $v$ Choice Hotels International, Inc, 265 F3d 931, 940-41 (9th Cir 2001) (finding an arbitration clause allowing the drafter to bring claims in court unconscionable); American General Finance, Inc, 793 S2d at 749 (citing the exemption of a drafting party from the duty to arbitrate to be an indicium of unconscionability); Armendariz, 6 P3d at 692 (finding that a unilateral obligation to arbitrate is "itself so one-sided as to be substantively unconscionable"); Iwen, 977 P2d at 995-96 (declaring an arbitration clause allowing only the drafting party to seek a legal remedy unconscionable); Flores $v$ Transamerica Homefirst, Inc, 93 Cal App 4th 846, 113 Cal Rptr 2d 376, 382 (2002) (finding an arbitration clause lacking a "modicum of bilaterality" invalid); Kinney, 83 Cal Rptr $2 \mathrm{~d}$ at 355 (applying the "modicum of bilaterality" test); Stirlen, 60 Cal Rptr $2 \mathrm{~d}$ at 152 (holding an arbitration clause providing the employer more rights and the employee fewer rights unconscionable). But see Munoz, 542 SE2d at 365 (declining to find an arbitration clause unconscionable solely because it allows the creditor to pursue foreclosure claims in court). 
ages recoverable in arbitration, ${ }^{207}$ if the clause precludes class action lawsuits, ${ }^{228}$ or if the clause does not permit adequate opportunities for discovery. ${ }^{2 \times 9}$ Courts have been particularly sympathetic to claims that arbitration is prohibitively expensive considering the plaintiff's resources $^{2 \times 1}$ or the value of the plaintiff's claim.

Assuming that courts wish to use the unconscionability doctrine to promote social welfare or protect buyers as a class, whether an arbitration clause is disadvantageous to the buyer when considered in isolation is too narrow a question to ask. The proper question is whether the costs to buyers exceed the benefits to sellers.

Defenders of arbitration claim it saves sellers money by eliminating the risk of aberrant jury decisions, limiting adverse publicity that can stem from litigation, minimizing litigation costs by streamlining discovery and largely avoiding appeals, among other reasons. ${ }^{2 \cdot 2} \mathrm{De}-$

287 See, for example, Ting, 182 F Supp 2d at 929; Armendariz, 6 P3d at 675 (involving a clause limiting employee's damages to back pay); Iwen, 977 P2d at 996 (discussing a clause limiting damages for a phone book advertisement to the cost of placing the advertisement); Powertel, 743 S2d at 576 (involving a clause prohibiting punitive damages).

288 See, for example, Ting, 182 F Supp 2d at 930-31; Leonard, 2002 Ala LEXIS 316 at *8; Szetela v Discover Bank, 97 Cal App 4th 1094, 118 Cal Rptr 2d 862, 866-68 (2002), cert denied, 123 S Ct 1258 (2003); Bolter v Superior Court, 87 Cal App 4th 900, 104 Cal Rptr 2d 888, 894 (2001); Ramirez v Circuit City Stores, 76 Cal App 4th 1229, 90 Cal Rptr 2d 916, 920 (1999); Powertel, 743 S2d at 576. Compare Jean R. Sternlight, As Mandatory Binding Arbitration Meets the Class Action, Will the Class Action Survive?, 42 Wm \& Mary L Rev 1,119-21 (2000) (arguing that prohibitions on class actions in contractual arbitration provisions should not be enforced).

289 See, for example, Hooters of America, Inc v Phillips, 39 F Supp 2d 582, 614-15 (D SC 1998) (finding an arbitration clause unconscionable where, among other factors, employee had limited discovery opportunity); Kinney, 83 Cal Rptr 2d at 354-55 (arguing that because the employer possessed most of the relevant evidence, limitations on discovery disadvantaged the employee).

290 See, for example, Cooper, 199 F Supp 2d at 781 (noting that the plaintiff would have been unable to pay arbitration fees).

291 See, for example, Comb v Paypal, Inc, 218 F Supp 2d 1165, 1177 (ND Cal 2002) (concluding that an arbitration provision would result in excessive cost because plaintiffs would be required to share in arbitration expenses when none of the plaintiffs' claims exceeded \$310); Leonard, 2002 Ala LEXIS 316 at *25 (invalidating an arbitration provision where "expenses of pursuing [the] claim far exceeds the amount in controversy"); Mendez v Palm Harbor Homes, Inc, 111 Wash App 446, 45 P3d 594, 604-05 (2002) (invalidating an arbitration clause that would require the plaintiff to "spend up front well over $\$ 2,000$ to try to vindicate his rights under a contract to buy a $\$ 12,000$ item in order to resolve a potential $\$ 1,500$ dispute"). See also, generally, Green Tree Financial Co v Randolph, 531 US 79, 82-83 (2000) (noting that an arbitration clause's silence with respect to costs that a party will have to bear in arbitration is not enough to invalidate the clause). For a detailed analysis of how federal courts respond to the argument that arbitration clauses in employment disputes make bringing claims prohibitively expensive, see generally Michael H. LeRoy and Peter Feuille, When Is Cost an Unlawful Barrier to Alternative Dispute Resolution? The Ever Green Tree of Mandatory Employment Arbitration, 50 UCLA L Rev 143 (2002) (finding a circuit split on the question and noting that the outcome depends largely on whether courts compare the costs of arbitration with court filing fees or with the full cost of litigation).

292 See, for example, Ware, $2001 \mathrm{~J}$ Disp Resol at 90 (cited in note 189) (explaining the arguments as to why arbitration saves money relative to litigation); Stephen J. Ware, The Effects of 
pending on the significance of these savings in a particular market, the benefit to buyers of even a one-sided arbitration clause, in the form of lower prices, might outweigh the costs of waiving their rights to invoke the jurisdiction of the public courts. ${ }^{293}$ To take one example, buyers would no doubt prefer that an arbitration clause be "bilateral" (both parties must resolve claims through arbitration) rather than "unilateral" (buyer must arbitrate claims but seller may litigate in court), all other things being equal. But if it is more cost-effective for sellers to pursue certain types of claims in court rather than through arbitration, ${ }^{244}$ buyers might be better off with a unilateral arbitration clause and, consequently, a lower price. ${ }^{295}$ It is possible, of course, that arbitration clauses are sometimes-or even perhaps always-inefficient. But courts rarely address this issue directly.

Two qualifications to this conclusion are appropriate. First, judges occasionally hint obliquely that their findings of substantive unconscionability might be based in part on their determination that the term in question is inefficient. For example, in finding an arbitration clause in a credit card contract unconscionable because the provision eliminated the possibility of class action suits, one court observed that the problematic provision "serves as a disincentive for [the credit card company] to avoid the type of conduct that might lead to class action litigation in the first place." ${ }^{247}$ In other words, the court appeared to suggest that the contractual limitation might create a moral hazard problem on the part of the seller. If so, the cost to buyers of the term might be greater than any resulting savings to the seller, thus reducing the efficiency of the transaction. In a recent case, AT\&T defended against a claim that its one-sided arbitration provision was unconscionable by arguing that by keeping its costs down it could charge customers less. ${ }^{2 y x}$ The court stated that it declined to find it was in the

Gilmer: Empirical and Other Approaches to the Study of Employment Arbitration, 16 Ohio St J Disp Resol 735, 746-50 (2001) (arguing that employers can benefit from employment arbitration through lower average awards and lower average process costs).

293 This is perhaps even more true for buyers of limited means, who are likely to be the most price-sensitive consumers of the underlying product ex ante.

294 For an explanation of why this might be true, see Ware, 2001 J Disp Resol at 97-98 (cited in note 189 ).

295 See Conseco Finance Corp v Wilder, 47 SW3d 335, 343 (Ky App 2001) (in upholding a one-sided arbitration clause, observing that "[a]rbitration is meant to provide for expedited resolution of disputes, but the claims the agreement permits [the defendant] to litigate - basically claims asserting its security interest -may be litigated expeditiously").

296 Compare Ware, $2001 \mathrm{~J}$ Disp Resol at 93 (cited in note 189) (chastising scholars who oppose the enforcement of arbitration clauses for failing to acknowledge that "harsh terms yield lower prices").

297 Szetela, 118 Cal Rptr 2d at 868. See also Powertel, 743 S2d at 576 (considering as a factor in a finding of substantive unconscionability the fact that elimination of a class action remedy removes deterrent effect that the threat of a class action suit has on a seller).

298 Ting, 182 F Supp 2d at 931 n 16. 
public's interest for companies to disclaim legal liability in order to lower the cost of doing business. ${ }^{299}$ Although somewhat opaque, the court's reasoning could be read as a conclusion that consumers in general would be better off paying more for telephone service and enjoying broader legal rights than paying less and enjoying more limited rights.

On more infrequent occasions, courts make clear that efficiency is at least one factor underlying a finding of substantive unconscionability. For example, one court claimed that a term was "patently unreasonable" because it allocated the risk of loss to the party least able to prevent the loss. ${ }^{3.0}$ It is important to underscore, however, that such hints of ex ante efficiency analysis are rare in published decisions finding unconscionability.

Second, even though courts ask the wrong question when examining contracts for substantive unconscionability, they might reach the proper result more often than not if there is a positive correlation between the existence of extremely one-sided terms and overall contractual inefficiency. For example, California courts have held that, to be enforceable, arbitration clauses must be bilateral unless the seller can prove that requiring buyers to arbitrate while retaining its ability to access the courts is justified by "business realities.", Theoretically, providing sellers with a preferential ability to litigate in court is desirable for both buyers and sellers if the benefits to sellers of such an exception to the "rule" of arbitration exceed the costs to buyers. But it is plausible that if a seller (a) believes that arbitration is generally efficient ex ante, but (b) cannot explain why it feels the need to draft a loophole applicable only to itself, then the exception most likely is not efficient."

299 Id (noting that AT\&T presented no evidence that any savings resulting from the contract term limiting remedies would be passed on to consumers).

$300 A \& M$ Produce, 186 Cal Rptr at 125.

301 Hints of an ex ante efficiency analysis appear in published opinions more often when courts enforce form terms. For example, upholding a forum selection clause in a form contract accompanying a cruise ticket, the United States Supreme Court observed that such clauses could save litigants costs associated with confusion as to the appropriate forum and that such clauses reduce cruise fares (although the Court did not attempt to compare the value of fare savings to the costs of the forum restriction). See Carnival Cruise Lines v Shute, 499 US 585, 594 (1991).

302 Armendariz, 6 P3d at 691. See also Stirlen, 60 Cal Rptr $2 \mathrm{~d}$ at 152 (finding a unilateral arbitration term unconscionable because no commercial justification for the term was offered).

303 See Armendariz, 6 P3d at 692 ("If the arbitration system established by the employer is indeed fair, then the employer as well as the employee should be willing to submit claims to arbitration."). 


\section{Conclusion}

Courts usually enforce terms provided in pre-printed form contracts, but they occasionally invalidate such terms, and they nearly always do so by way of the unconscionability doctrine. The two-step framework adopted by most courts requiring both procedural and substantive unconscionability for the term to be invalidated is reasonable if understood as encouraging courts to look first for indicia of market failure and second for evidence that the term is undesirable. But neither test is implemented in a way that is well-tailored to the problem that boundedly rational consumer choice processes provide sellers with incentives to offer low quality when terms are non-salient.

Some factors that courts have identified as demonstrating procedural unconscionability, such as the existence of a situation-specific monopoly, an uneducated buyer, or the printing of terms that makes them difficult to read, might be positively correlated with terms being non-salient and therefore possibly inefficient. At best, however, these factors are weak indicators of non-salience, and are significantly under- and overinclusive.

Substantive unconscionability analysis generally results in courts inquiring into how undesirable a term is for a plaintiff ex post, rather than whether the package of terms and price is efficient and desirable for buyers ex ante relative to other economically feasible combinations of terms and price. Terms identified as substantively unconscionable by courts using this approach might also bear a positive correlation to terms that are inefficient, ${ }^{3 / 4}$ but the fit is unlikely to be very precise. Thus, although it is possible that social welfare is better served by judicial use of the unconscionability doctrine than it would be by blanket enforcement of all form terms, the fit between problem and solution seems quite far from optimal.

\section{MODIFYING THE UNCONSCIONABILITY DOCTRINE}

In light of the incentives for sellers to draft form contract terms that are low quality rather than efficient and the inherent difficulty of enacting mandatory contract terms that anticipate all potential form terms and are efficient in all circumstances, ex post judicial review of form contract terms, as provided by the unconscionability doctrine, is

304 In an article studying thirty years' worth of case outcomes, Daniel Ostas claims that contract terms that allocate costs inefficiently are likely to be found unconscionable. Daniel T. Ostas, Predicting Unconscionability Decisions: An Economic Model and an Empirical Test, 29 Am Bus L J 535, 559-66 (1991). The validity of the conclusion depends on the ability of the author to correctly determine which terms are efficient and which are inefficient merely from the facts available in judicial opinions. Nonetheless, his analysis suggests that perhaps judges are biased against inefficient terms in general, even if their description of the doctrine does not suggest that case outcomes are likely to separate efficient from inefficient terms. 
appropriate. Because the market should ensure that certain form terms are efficient while offering no such assurance for other terms, it is also sensible for courts to screen contracts for terms that are likely to be inefficient and apply substantive scrutiny only to those terms. Thus, the division of the unconscionability doctrine into procedural and substantive prongs is also appropriate. The factors that courts use as indicia of procedural unconscionability are not the factors that imply the market cannot be relied upon to guarantee efficiency, however. And the courts' approach to substantive unconscionability analysis is not well-suited to separating terms that are detrimental to buyers as a class from those beneficial to buyers as a class.

Both prongs of the doctrine can be improved substantially by modifying the list of factors that trigger courts' findings of unconscionability. Because the factors that trigger findings of either procedural or substantive unconscionability are entirely judge-made rather than specified by statute, courts can legitimately modify their approach to identifying unconscionability without legislative approval.

Modifying the unconscionability doctrine to create the closest possible fit between the doctrine and either social welfare or buyer welfare requires adherence to four principles:

(1) Employ the screening device of "procedural unconscionability" to sort contract terms into two groups: those highly likely to be efficient, and those most likely to be inefficient.

(2) Use "substantive unconscionability" analysis to identify the terms in the latter category that actually are inefficient.

(3) In order to minimize "false positives"-decisions that terms are unconscionable when they are, in fact, efficient-defer to terms included in form contracts in inconclusive cases.

(4) In order to provide sellers with an incentive to draft efficient terms even when those terms are non-salient, provide substantial remedies to victims when terms are found unconscionable by courts.

This Part operationalizes these principles.

A. Non-Salience as the Touchstone of Procedural Unconscionability

1. Salience as the procedural screening device.

When a contract term is salient to buyers and thus priced as part of their purchase decisions, sellers must provide an efficient version of 
the term to remain competitive. When a term is non-salient to buyers, however, market pressure will force sellers to provide a low-quality version of the term. The term provided might be efficient, of course, but there is no a priori reason to believe it will be. Thus, before considering the possibility of invalidating a form contract term, courts should initially inquire into whether a challenged term is salient or non-salient. Salient terms should be enforced as presumptively efficient, and non-salient terms should be subjected to further substantive analysis.

Because salient form terms should always be efficient whereas non-salient terms will only sometimes be inefficient, form terms should be enforced when it is uncertain whether they are salient or non-salient. Thus, courts should require buyers to bear the burden of proving non-salience. This burden of proof presents an evidentiary challenge for buyers who seek judicial invalidation of terms, but one that is no worse than that faced by litigants in other contexts. Trademark infringement lawsuits provide an example. To prove trademark infringement, the plaintiff must prove that "an appreciable number of reasonable buyers" are likely to be confused by the similarity between the defendant's and plaintiff's marks. ${ }^{\text {s.t }}$ As proof, plaintiffs routinely submit surveys of actual and potential customers of the product in question, which can then be challenged by defendants' expert witnesses. ${ }^{3,1}$ Alternatively, plaintiffs can present as evidence the testimony of consumers who were actually confused. ${ }^{314}$

When the salience of form contract terms is at issue, buyers might present studies that demonstrate what percentage of customers in a particular market reported considering the term in question when making their purchase decision, selected one seller over another because of the content of that term, or were even aware of the content of that term in their particular contract. Although this type of investment in litigation often will not be cost-justified for a plaintiff challenging a single contract, it might be indicated more frequently in class action lawsuits. Where market studies are infeasible, plaintiffs might offer weaker, but undoubtedly relevant, evidence, such as testimony concerning the salience of a particular term by a number of different buyers. Sellers could, of course, counter this with conflicting testimony, re-

306 See J. Thomas McCarthy, 3 McCarthy on Trademarks and Unfair Competition $\S 23.2$ (West 2002).

307 See, for example, Mutual of Omaha Insurance Co v Novak, 836 F2d 397, 400 (8th Cir 1987); Exxon Corp v Texas Motor Exchange Inc, 628 F2d 500, 506-07 (5th Cir 1980); McDonald's Corp v McBagels, Inc, 649 F Supp 1268, 1277-78 (SD NY 1986).

$30 \times$ See, for example, Sara Lee Corp v Kayser Roth Corp, 81 F3d 455, 466 (4th Cir 1996) (finding evidence of confusion "nearly overwhelming" based on testimony of six buyers and store employees). 
quiring the court to make an informed although imperfect estimate as to the extent of the salience of the term in question.

Focusing the procedural unconscionability inquiry on the question of salience in this way clearly invites an intensely factual inquiry, thus making it difficult for courts to resolve disputes on motions for summary judgment, at least when salience is in dispute. But this problem would be no worse than it is under current doctrine, which requires courts to consider factual evidence concerning the "commercial setting, purpose and effect" of challenged contract terms.

\section{Salient to how many?}

In today's complex world, most products will have dozens, if not hundreds, of distinct attributes. Because individuals are likely to be able to process only five to ten of these under usual circumstances, ${ }^{311}$ and because, in general, form terms are particularly likely to be nonsalient relative to other product attributes, ${ }^{3 \prime \prime}$ many form contracts will have terms that are salient to few, if any, buyers. Other terms, however, will be salient to a significant percentage of buyers and non-salient to a significant percentage of buyers. In this circumstance, for how many buyers must the term be salient for a court to uphold the term without further substantive review?

In theory, if a term is non-salient to any non-trivial percentage of buyers-understood as enough buyers to support one or more sellers - contracts involving those buyers might include an inefficient version of the term. Because nearly all terms (excluding perhaps price) will be non-salient to some buyers, however, the value of employing a screen to narrow the field of terms subject to substantive review would be severely undermined if a high threshold for such review were not employed. In order to preserve the value of substantial certainty in contract law and to focus judicial resources on examining the terms most likely to be inefficient, courts should require a buyer to prove that the term in question is non-salient to a substantial majority of buyers. This threshold might be relaxed somewhat by courts upon a showing that the term is subject to adverse selection, such that buyers for whom the term is salient are undesirable customers. In the presence of an adverse selection risk, the likelihood is greater that sellers will appeal to buyers for whom the term is non-salient, and thus offer low-quality term content regardless of its efficiency.

309 UCC \$ 2-302(2). See also John D. Calamari and Joseph M. Perillo, The Law of Contracts \$ 9-39 at 404 (West 3d ed 1987) (concluding that "[m]any cases have held that [this] provision mandates an evidentiary hearing or a full fledged trial on the merits").

310 See Part II.B.

311 See Part II.C. 
3. Salience to the buyer(s) challenging the term.

The proper application of the salience screen requires courts to ignore whether a form term is salient to the complaining plaintiff personally. The existence of a pre-printed form contract with adhesive terms implies that the joint costs to buyers and sellers of negotiating individualized terms outweighs the potential benefits of doing so. This means that if a term is salient for every buyer except for "Customer," sellers who provide terms on a standardized form will offer an efficient version of the term to all, including Customer, so that they can compete for all the other buyers. In this situation, market forces should assure that Customer will benefit from standardization, even though, if bargaining costs were not an issue, the seller theoretically could provide a low-quality term to Customer with no compensating concessions on price or other attributes. Thus, the fact that a term is non-salient to Customer personally does not suggest that the market will provide low quality whether or not low quality is efficient, and it should not trigger substantive scrutiny of the term."

In the opposite situation, in which a term is non-salient to every buyer except for Customer, courts should not allow a seller to avoid substantive scrutiny of the term merely by demonstrating that it was salient to Customer. Sellers will foist on a large population of buyers for whom a term is non-salient a low-quality version of that term, even though doing so means risking the loss of Customer's patronage. The fact that a seller provides terms on a standard form implies that altering terms for a single buyer with eccentric concerns would not be cost justified. If this were not the case, of course, the seller would hold itself out as willing to negotiate terms. Thus, the lack of salience of a term to all buyers except Customer will lead sellers to offer the same lowquality term, whether or not efficient, leaving Customer without any alternatives. If Customer is not a marginal buyer whose entire potential consumer surplus is destroyed by the inefficient term, she will purchase the product along with the low-quality term, even though the term is both salient to her and inefficient. ${ }^{3.13}$ Thus, the salience of a par-

312 Compare Rakoff, 96 Harv L Rev at 1251 (cited in note 4) (arguing that whether a particular consumer "shopped" a term should not be a legally relevant consideration). This conclusion also means that the proposed approach to applying the unconscionability doctrine does not provide buyers with a perverse incentive to ignore.

313 If Customer is a marginal buyer whose entire consumer surplus is destroyed by the inefficient term, she is not likely to purchase the product. In theory, she might purchase the product if she believes that there is a high probability that the court will refuse to enforce the inefficient term and that she can win a judicial ruling at a low-enough cost that her consumer surplus will not be destroyed through litigation. Given the high cost of litigation, it seems highly unlikely that these requirements would ever hold. If the consumer surplus available from a given term would ever exceed the costs of litigation, it seems likely that sellers would negotiate that term, rather than offer it via a pre-printed form. 
ticular term to Customer alone cannot serve as a seller's defense to an unconscionability claim.

Ironically, if a buyer for whom a particular term is salient (a) knows that she is an inframarginal buyer, and thus would prefer to purchase the good even if it is accompanied by an inefficient term, and (b) suspects that the term is non-salient to most other buyers, she might reasonably decide not to even read the term herself, because learning the content of the term would not affect her purchase decision. Consequently, the reading of form terms might be subject to a tipping point effect: If a term is non-salient to most buyers, it is likely that virtually no buyers will read that term. It is this problem, perhaps, that courts implicitly recognize when they base a procedural unconscionability finding on homogeneity of terms within an industry, despite a lack of evidence that the plaintiff attempted to shop or read the term, ${ }^{3 / 4}$ though courts uniformly fail to articulate the problem this way. ${ }^{315}$

\section{B. Substantive Unconscionability Analysis: Ex Ante Efficiency}

Form terms that are non-salient will be low quality, but this, of course, does not mean that they necessarily will be inefficient. In many cases, allocating low-probability risks to buyers, limiting buyer remedies, expanding seller remedies, or limiting litigation options of one or both parties will be efficient, as benefits to the parties jointly in the form of reduced costs of producing or providing the product will exceed the joint costs of lost benefits, reduced flexibility, or undesirable incentives. Thus, form contract terms that are non-salient cannot be rejected as unenforceable on this basis alone; they should be evaluated on the basis of their ex ante social efficiency. Specifically, as part of their "substantive unconscionability" analysis, courts should examine whether the benefits of a low-quality term to the seller in the form of savings in production, distribution, and sales costs exceed the value of an alternative term to potential buyers. If they do, the term is efficient (and better for buyers as a class than the alternative term). If they do not, the term is inefficient (and its enforcement would make buyers as

314 See, for example, Henningsen, 161 A2d at 87 (noting the warranty disclaimer was part of a form contract used by 93.5 percent of car manufacturers).

315 Notice that using a salience screen as the first step in the unconscionability analysis as proposed in this section will not create a perverse incentive for buyers to ignore even salient terms in reliance on judicial protection. If a term is salient to most buyers, courts will defer to the content of that term provided by the market, so individual buyers for whom the term is salient have an incentive to price that term as part of their purchase decision. If a term is salient to few buyers, an individual buyer for whom the term is salient (and who knows he is an inframarginal purchaser) has no incentive to price the term as part of his purchase decision, but this incentive is no different than the incentive he would have if courts deferred entirely to the content provided in form contracts. 
a class worse off than they would be if a high-quality term were substituted).

In the best of circumstances, this inquiry could be resolved by reference to specific evidence. For example, courts could compare studies of buyers' willingness to pay for a high-quality term relative to a low-quality term (presumably provided by plaintiffs) with projections of the marginal savings to the seller from providing the lowquality term (presumably provided by defendants). When such direct evidence is unavailable, however, courts will have to rely on more general theoretical principals, familiar to all law-and-economics scholars. For example, efficient allocations usually assign risks to the party best able to avoid a potential loss or able to avoid the loss most cheaply, in order to provide the maximum incentive for that party to take the necessary precautions. ${ }^{316}$ If a risk is largely unmanageable, efficiency demands that the risk be assigned to the party best able to predict its likelihood of occurring so as to be able to insure against it, or to the party able to insure against the risk at the lowest cost. ${ }^{317} \mathrm{Im}$ portantly, courts cannot resort merely to an examination of industry custom, as uniformity among sellers concerning non-salient terms is the expected result of market pressure whether or not the chosen term is efficient.

When a court determines that a term is inefficient, it should invalidate the term as unconscionable. Although this approach would alter somewhat the doctrinal definition of unconscionability, the modified approach does justice to the moral connotation of the word "unconscionable" if one considers the obligation of sellers to buyers as a class rather than to a single buyer. Providing terms that reduce social welfare and make buyers as a class worse off than they otherwise would be is unconscionable behavior, although it often is not labeled as such under the prevailing application of the unconscionability doctrine. Providing a term that increases social welfare and makes buyers as a class better off, but leaves a particular buyer worse off ex post is not unconscionable behavior, although it is often labeled as such under current jurisprudence (and clearly is unfortunate for the unlucky buyer).

316 See, for example, $A \& M$ Produce $v$ FMC Corp, 135 Cal App 3d 473, 186 Cal Rptr 114, 125 (1982) (concluding that the risk of loss caused by a machine should be borne by the manufacturer-seller, who is best able to prevent a loss from occurring, rather than by the buyer).

317 See, for example, Posner, Economic Analysis of Law $\$ 4.5$ at 104-10 (cited in note 25).

318 See Part II.D.1. 


\section{The Presumption of Enforceability}

Judicial determinations of which contract terms are efficient and which terms are inefficient are subject to a high likelihood of error. ${ }^{319}$ The substantial institutional competence problem manifested by judges attempting to reach conclusions about industry-wide benefits and costs in the context of an individual dispute is not so severe as to suggest all form terms should be automatically enforced. The problem is severe enough, however, that a modified unconscionability doctrine should seek consciously to minimize the likelihood of judges determining that form terms are inefficient when they are actually efficient; that is, "false positives" should be minimized.

In many instances, whether a term embedded in a form contract is or is not efficient will be unclear: Evidence will be incomplete, or some pieces of evidence will imply efficiency while others will imply inefficiency. To minimize judicial false positives, courts should interpret the unconscionability doctrine to include an implicit presumption against invalidating terms included in form contracts - even when the court has determined that the term is non-salient to a substantial majority of buyers. Judges should only invalidate terms embedded in form contracts when the evidence that the term is inefficient satisfies a "clear and convincing" standard.

The presumption in favor of enforceability has the benefit of promoting a large measure of certainty concerning contractual rights and responsibilities. Sellers as a group, as well as buyers, are better off if the law provides an incentive for them to provide efficient terms, so everyone benefits from a doctrine that empowers courts to strike down clearly inefficient terms. But sellers and buyers are harmed if their contractual obligations are routinely unclear at the time of contracting, making it difficult to price goods and plan for future contingencies.

\section{Remedies for Unconscionability: Incentives for Sellers}

As the unconscionability doctrine evolved from the courts' equity jurisdiction, most courts believe that the doctrine gives judges broad latitude to determine appropriate remedies for violations. ${ }^{3211}$ The Uniform Commercial Code is in agreement, providing that, upon a finding of unconscionability, courts may "refuse to enforce the contract ... [,]

319 See Part III.C.2.

320 See, for example, County Asphalt v Lewis Welding and Engineering Corp, 444 F2d 372, 379 (2d Cir 1971) (noting that equitable relief is granted "according to the 'conscience' of the chancellor"); Williams v Walker-Thomas Furniture Co, 350 F2d 445, 448 (DC Cir 1965) (suggesting that a court should give a party who sues under an unconscionable contract "only such as he is equitably entitled to"), quoting Scott v United States, 79 US (12 Wall) 443, 445 (1870). 
enforce the remainder of the contract without the unconscionable clause," or "limit the application of any unconscionable clause.", In current unconscionability jurisprudence, there is no clear consensus concerning which of these remedies is most appropriate.

Of the remedial options generally considered appropriate by courts, reformation of the offending term is the least disruptive to the contracting parties. ${ }^{322} \mathrm{~A}$ court seeking to reform an unconscionable term effectively rewrites that term, but the contractual relationship between the buyer and seller otherwise proceeds as the contract provides. For example, finding an arbitration clause specifying arbitration with the International Chamber of Commerce unconscionable because of the high fees charged by that organization, one appellate court remanded the case to the trial court with instructions to substitute another less expensive arbitrator, ${ }^{323}$ rather than refusing to enforce the arbitration clause or the entire contract. In older cases, upon finding that a seller charged an unconscionable price, courts have ordered the price term of a contract changed. ${ }^{34}$

The primary problem with the reformation remedy is that it provides no incentive for sellers to resist the market pressure to provide low-quality non-salient form terms even when low-quality terms are inefficient. ${ }^{325}$ Most buyers will abide by the form term rather than challenge it, giving the seller a windfall. In the unusual case that the term is challenged and found unconscionable by a court, the seller is no worse off than it would have been if it had provided an efficient term initially. ${ }^{326}$ Consequently, unconscionable terms will be avoided only when courts intercede in private contracting arrangements and invali-

321 UCC \& 2-302(1).

322 The California Supreme Court, which has considered the subject of unconscionability remedies in the greatest detail, recently ruled that California courts may invalidate clauses, terms, or entire contracts based on an unconscionability finding, but that they may not reform contracts by rewriting terms. See Armendariz, 6 P3d at 695 .

323 Brower v Gateway 2000, Inc, 676 NYS2d 569, 575 (NY App Div 1998). See also Leonard v Terminix International Co, 2002 Ala LEXIS 316, *26 (Woodall dissenting) (calling for an arbitration term to be reformed to require the seller to pay costs of arbitration rather than invalidating the arbitration term on the grounds that the costs to the buyer of arbitrating would exceed the costs of the claim).

324 See Frostifresh, 281 NYS2d 964 (reversing lower court decision limiting seller's recovery to the cost of a refrigerator-freezer and allowing seller to recoup cost plus reasonable profit); Jones v Star Credit Corp, 59 Misc 2d 189, 298 NYS2d 264, 268 (NY Sup Ct 1969) (reforming and limiting a price term to the amount buyer had already paid).

325 See, for example, Arthur Allen Leff, Unconscionability and the Crowd-Consumers and the Common Law Tradition, 31 U Pitt L Rev 349, 354-56 (1970) (calling unconscionability litigation an undesirable method of dealing with unfair terms because sellers will change their business practices only slightly, if at all, as the result of an unfavorable ruling).

326 See Perez v Globe Airport Security Services, Inc, 253 F3d 1280, 1287 (11th Cir 2001), vacd, 294 F3d 1275 (11th Cir 2002) ("If an employer could rely on the courts to sever an unlawful [portion of an arbitration term] and compel the employee to arbitrate, the employer would have an incentive to include unlawful provisions in its arbitration agreements."). 
date terms. Given both the high cost of litigation and the recommended presumption of enforceability in unclear cases, ${ }^{327}$ a remedy of reformation would ensure that inefficient terms would be commonplace in form contracts.

Most frequently, courts invalidate the unconscionable term (or portion of a term), thus leaving the parties to rely on the remaining form terms or law-provided, gap-filling default terms. Whether the threat of this remedy provides an incentive to sellers not to overreach depends on the content of the default terms in question. If the default term is extremely undesirable to a seller, that seller will have an incentive to draft a replacement form term that is efficient and thus would not run a risk of being found unconscionable by a court. If the default is acceptable to the seller, however, it would have an incentive to draft a low-quality form term, even if inefficient, knowing that it will enjoy the benefits of that term when buyers do not litigate, and that the worst-case scenario would be for a court to replace the form term with the relatively unobjectionable default.

Somewhat less frequently, courts refuse to enforce an entire term (or set of terms) even when only a portion of it is unconscionable ${ }^{328}$ or even refuse to enforce an entire contract when parts of it are unconscionable. ${ }^{32 y}$ Providing this remedy to the victim of an unconscionable term is obviously the most draconian of the plausible remedial options, and it is most disruptive to the relationship between the buyer and seller. Depending on what elements of the contract have been performed and what has led to the litigation between the parties, refusing to enforce the entire contract could strip the seller of contractual protections it wrote into the boilerplate or prevent the seller from seeking contractual remedies against the buyer, requiring it instead to resort to quasi-contract principles. But non-enforcement substantially increases sellers' incentives to attempt to provide efficient terms in the first instance, ${ }^{3,0}$ even when the terms are non-salient to most buyers. $^{331}$

327 See Part V.C.

328 See Ferguson $v$ Countrywide Credit Industries, Inc, 298 F3d 778, 788 (9th Cir 2002) (invalidating entire arbitration contract where several clauses were found unconscionable); Ting $v A T \& T, 182$ F Supp 2d 902, 936 (ND Cal 2002) (refusing to enforce all "Legal Remedies Provisions" of a contract where terms were "permeated with unconscionability and illegality"); $A r$ mendariz, 6 P3d at 696-97 (invalidating an entire arbitration contract where several clauses were found unconscionable); Pittsfield Weaving Co, Inc v Grove Textiles, Inc, $121 \mathrm{NH} \mathrm{344,430} \mathrm{A2d} 638$ (1981) (refusing to enforce an arbitration requirement where the contract required that all disputes be filed with an arbitrator in an unreasonably short period of time).

329 See, for example, Bank of Indiana v Holyfield, 476 F Supp 104, 111 (SD Miss 1979) (refusing to enforce a lease contract for livestock where the plaintiffs received a "tremendous return" and the entire risk of loss of the livestock was allocated to the defendant).

330 See, for example, Hillman, 67 Cornell L Rev at 28 (cited in note 180) (speculating that the threat of an unconscionability finding might deter sellers from including suspect terms in 
Few courts have analyzed in detail or even attempted to explain their choice of unconscionability remedies, but those that have done so have relied on the contractual doctrine of severability, ${ }^{3,2}$ most often invoked to sever illegal from legal portions of a contract. ${ }^{33}$ The principle underlying the severability doctrine is that the parties' contractual relationship should be maintained to the maximum extent possible if the parties are innocent of wrongdoing. ${ }^{3.4}$ Thus, if the core purpose of a contract is legal but a collateral term is illegal, courts will invalidate only the illegal term rather than the entire contract. ${ }^{3.55}$ Relying on the analogy to illegal terms, some courts have found it prudent to invalidate only the unconscionable portion of the contract, rather than an entire term or the entire contract. ${ }^{3.6}$

The severability doctrine does not require deference to parties who knowingly include illegal terms in their contracts, however. As one court has observed, to do so would only encourage overreaching by drafting parties. ${ }^{377}$ This reasoning applies with even greater force to unconscionability, because courts are much more poorly suited to determine whether or not a term is efficient than they are to determine whether a term is illegal. In light of this, and especially if deference is given to seller-drafted terms that are not clearly inefficient, ${ }^{338}$ it is important for courts to provide sellers with the maximum incentive not only to attempt to draft efficient non-salient form terms, but also to invest time and resources in doing so.

Providing such an incentive requires courts, on a finding of unconscionability, to severely limit enforcement of the contract in question to deter other sellers from similar bad faith or carelessness. Put in

their contracts).

331 See Craswell, 33 Osgoode Hall L J at 217 (cited in note 168) (noting, in the case of coercion, that non-enforcement can be an appropriate remedy when the defendant has the ability to avoid the conditions that give rise to the plaintiff's claim, but only reformation is appropriate when the defendant has no control over those conditions).

332 Armendariz, 6 P3d at 695-99 (invalidating entire arbitration contract because unconscionable provisions were too numerous to sever and noting that courts have tended to invalidate the entire contract rather than sever the illegal term in order to create incentives for the drafting party to avoid including questionable terms).

333 Perez, 253 F3d at 1286-87 (discussing severability of illegal arbitration provisions). See generally Data Management Inc v Greene, 757 P2d 62, 64-65 (Alaska 1988) (discussing three different approaches to severability of illegal terms).

334 See Armendariz, 6 P3d at 697 (noting that courts tend to employ the doctrine of severability where there is no evidence of "bad faith").

335 See id at 697 (noting that courts generally sever an illegal term if the remaining portions of the contract are not tainted).

336 See Data Management, $757 \mathrm{P} 2 \mathrm{~d}$ at 64 (arguing that courts should invalidate only the illegal term in order to strike a balance between "protecting the rights of the parties to enter into contracts" and "the need to protect parties from illegal contracts").

337 Id at 65.

338 See Part V.C. 
different terms, courts should recognize a right of buyers to be free of unconscionable contracting behavior, and this right should be protected with a "property rule" rather than a "liability rule.",

Whether this principle counsels for non-enforcement of the entire contract or only a portion of it will depend on the nature of the litigation that gives rise to the unconscionability determination. In Armendariz, the California Supreme Court found that an arbitration clause in a form employment contract contained several unconscionable provisions and thus refused to enforce the entire clause. ${ }^{3.11} \mathrm{Be}$ cause the employee plaintiffs were seeking to sue the employer for discrimination, ${ }^{341}$ it would have provided no benefit to the victimized employees for the court to hold the entire employment contract was unenforceable. Thus, the court created the greatest possible deterrent effect by invalidating the entire arbitration agreement, but not the complete employment contract. However, when a seller attempts to use an unconscionable term as a sword rather than a shield-for example, by relying on an unconscionable collection term to sue a buyer for damages - courts will maximize deterrence by refusing to enforce the entire contract. Because sellers in a product market often use identical or similar form terms, judicial use of the non-enforcement remedy against one seller will have a strong deterrent effect on other sellers as well.

Although the need to provide the maximum incentive for sellers to ensure that even non-salient form terms are efficient suggests that non-enforcement should be the default remedy for a finding of unconscionability, it is appropriate for courts to order more limited remedies when sellers fail in a good faith attempt to provide efficient terms.

This Article has emphasized the problem of buyer bounded rationality, because it is buyer behavior that provides incentives for sellers to draft efficient or inefficient form terms. ${ }^{32}$ But sellers, like buyers, are boundedly rational rather than fully rational decisionmakers. Designing efficient contract terms requires sellers to estimate their likely costs or cost savings under various possible terms and compare those to the expected value to buyers as a class of various possible terms. Evidence that a seller made an honest but failed attempt to conduct such an analysis rather than focusing single-mindedly on minimizing its costs should result in the invalidation of only the unconscionable portion of the term at issue. The level of effort in pursuit

339 See generally Richard Craswell, Property Rules and Liability Rules in Unconscionability and Related Doctrines, 60 U Chi L Rev 1 (1993) (observing that remedies for unconscionability can be classified according to the property rules/liability rules dichotomy).

341) 6 P3d at 697.

341 Id at 674 .

342 See note 53. 
of efficient terms necessary to support a more lenient remedy should depend on the economic value of the contract at issue. A large corporation with hundreds of millions of dollars in sales and an in-house legal department should be expected to invest more resources and conduct a more sophisticated analysis when drafting form contracts than a small business with $\$ 500,000$ in annual sales and a single lawyer on retainer.

\section{E. Conclusion}

There is no perfect solution to the problem that sellers have an incentive to provide low-quality non-salient terms in form contracts. A second-best approach to the problem requires a legal doctrine that recognizes the source of contractual inefficiency and focuses judicial attention on the form terms most likely to be inefficient. In addition, the doctrinal design should attempt to minimize false positives (terms that a court invalidates but are actually efficient) and false negatives (terms upheld by courts that are inefficient). By modifying the factors that serve as indicia of procedural and substantive unconscionability, by granting deference to form terms in close cases, and by providing substantial remedies to victims when terms are found to be unconscionable in spite of this deference, the unconscionability doctrine can be an element of a second-best solution. To be sure, a modified unconscionability doctrine will not guarantee the disappearance of all contractual inefficiency, but it will result in greater social welfare, and thus in greater welfare for buyers as a class, than the doctrine as it is currently applied by courts.

\section{CONCLUSION: "RATIONALITY" AND INSTITUTIONAL COMPETENCE}

Interdisciplinary behavioral science research presents substantial evidence that individuals employ decisionmaking processes that will often deviate from the predictions of narrow versions of rational choice theory. ${ }^{\text {a. }}$ The evidence that individuals systematically use heuristics in decisionmaking behavior that can result in the failure to maximize expected utility in particular cases raises two distinct questions of interest to legal scholars: (1) is boundedly rational decisionmaking "rational" behavior or the consequence of cognitive limitations, and (2) what are the implications of bounded rationality for the law?

As to the first question, some devotees of rational choice theory might wish to describe boundedly rational decisionmaking of the type

\footnotetext{
343 See generally Korobkin and Ulen, 88 Cal L Rev at 1075-126 (cited in note 49) (collecting the results of the studies).
} 
discussed in this Article as, in fact, fully rational decisionmaking under the constraints of information costs. ${ }^{344}$ The plausibility of this characterization depends, I believe, on context.

People are not computers, and we lack the memory and computational ability to conduct a thorough weighted-adding analysis of highly complex problems. An example commonly used to illustrate this point is the game of chess. The goal of the chess player is to checkmate the opponent. The player can maximize his chances of achieving this goal, and thus his utility, by comparing every possible series of moves he could make and the counter moves with which his opponent could respond. Unfortunately, there are more than $10^{120}$ possible combinations of moves in a game of chess ${ }^{345}$-more than humans can processforcing even master players to adopt simplified strategies for choosing moves. No matter how much effort a chess player is willing to exert, he cannot optimize. $^{346}$ It follows that, at least in extreme cases, buyers do not choose to trade off accuracy of decisions to reduce effort; no other options are available. Calling cognitive limitations a "transaction cost" in this type of situation would wrongly imply that buyers could make the choice to achieve higher levels of accuracy if only they were willing to pay the price, when these limitations are, in fact, immutable. ${ }^{3.77}$

In the context of simpler choice problems for which buyers could conduct something like a weighted-adding analysis, cognitive limitations could be understood more plausibly as a type of transaction cost. Evidence suggests that when faced with the moderately complex type of choice problem that buyers routinely experience, most individuals would have difficulty achieving the theoretical level of accuracy that a non-selective and compensatory decisionmaking approach could produce. $^{348}$ This fact alone, however, does not demonstrate that the failure

344 For example, Grether, Schwartz, and Wilde discuss information acquisition and information processing as two costs of decisionmaking that rational consumers making decisions must balance against the benefits that they can provide. See $59 \mathrm{~S} \mathrm{Cal} \mathrm{L} \mathrm{Rev} \mathrm{at} \mathrm{287-88} \mathrm{(cited} \mathrm{in} \mathrm{note}$ 48). See also Posner, Economic Analysis of Law $\$ 1.3$ at $17 \&$ n 1 (cited in note 25) (calling "bounded rationality" consistent with the economic model of "rationality"). This view is by no means universal in the law-and-economics community. See, for example, Posner, 112 Yale $\mathrm{L} J$ at 865 (cited in note 33) (stating that law-and-economics contract law scholarship "purports to assume that individuals are rational in the sense of neoclassical economics," and thus that "their cognitive capacity is infinite").

345 See Herbert A. Simon, Theories of Bounded Rationality, in Herbert A. Simon, 2 Models of Bounded Rationality: Behavioral Economics and Business Organization 408, 413 (MIT 1982).

346 Id at 415 (explaining that chess players adopt "stopping rules" to limit their search).

347 See Herbert A. Simon, A Behavioral Model of Rational Choice, 69 Q J Econ 99, 99 (1955).

348 See, for example, Laurence Paquette and Thomas Kida, The Effect of Decision Strategy and Task Complexity on Decision Performance, 41 Org Beh \& Human Dec Processes 128, 132-39 (1988) (finding that, in the context of a particular problem-solving task, a weighted-adding strategy would theoretically identify more correct answers than an elimination-by-aspects strategy, but that subjects instructed to use the former strategies did not achieve significantly higher levels 
to make accurate choices is not the result of individuals' decisions that the marginal costs of accuracy in terms of effort exceed the marginal benefits. A well-educated buyer could construct a spreadsheet that lists all relevant alternatives and attributes, weighs the attributes, assigns relative utilities to each alternative on each attribute, and then compares the expected utility of each alternative; those who are less facile with decision-analysis techniques could hire professionals to conduct such an analysis for them. The cost of either of these alternatives in time, effort, money, and perhaps emotional stress ${ }^{349}$ will outweigh the marginal benefits of conducting a thorough weightedadding analysis - at least for most everyday decisions - thus suggesting that use of a simplifying heuristic would be indicated from a cost/benefit perspective.

In this situation, is it accurate to describe an individual's decision to sacrifice accuracy in order to minimize effort as a "rational" choice? The answer to the question posed in this way is surely "yes." "31 But to end the analysis here surely would fail to take notice of something unique about the problem that differentiates it from situations in which obtaining information is costly. Employing simplifying heuristics is a rational approach to decisionmaking only because of our cog-

of accuracy than did subjects instructed to use the latter strategy); Kevin Lane Keller and Richard Staelin, Effects of Quality and Quantity of Information on Decision Effectiveness, $14 \mathrm{~J}$ Consumer Rsrch 200, 208-09 (1987) (finding that when more than 6.8-8 attributes per alternative were described but the usefulness - for the purpose of identifying the correct choice - of the information conveyed by the set of attributes as a whole was held constant, subjects' decision accuracy decreased). Compare with Bettman, Luce, and Payne, $25 \mathrm{~J}$ Consumer Rsrch at 187 (cited in note 51) (claiming that the information-processing approach to consumer decisionmaking endorses "the notion that decisionmakers have limitations on their capacity for processing information").

349 See, for example, Eisenberg, 47 Stan L Rev at 216 (cited in note 45) ("That actors limit search and processing does not necessarily mean that they fail to rationally maximize their total utility in making decisions. An actor's total utility from a decision depends not only on the substantive merits of the decision, but also on the costs of the decisionmaking procedure."). See also Schwartz, 55 Am Psychologist at 85 (cited in note 78) (speculating that increases in clinical depression might be based on the expectation that, with so many choices available, people believe that their lives should be perfect rather than "good enough").

350) See George J. Stigler, The Economics of Information, $69 \mathrm{~J}$ Polit Econ 213 (1961) (positing that individuals search for information until the marginal cost of continued search exceeds the marginal returns, at which point the search ends); Hogarth, Judgement and Choice at 71 (cited in note 58) (noting that both acquiring and processing information have associated costs).

351 See Hillman and Rachlinski, 77 NYU L Rev at 436 (cited in note 2) ("The consumer, engaging in a rough but reasonable cost-benefit analysis ... understands that the costs of reading, interpreting, and comparing standard terms outweigh any benefits of doing so and therefore chooses not to read the form carefully or even at all."); Sunstein, 112 Yale $\mathrm{L} \mathrm{J}$ at 75 (cited in note 111) ("[W]hen the probability [of harm] is really low, it may be sensible to treat it as if it were zero."); Meyerson, 24 Ga L Rev at 597-98 (cited in note 46) ("[S]ubordinate terms will not be known because the cost of acquiring the necessary information exceeds the expected gain to the consumer from that information."); Grether, Schwartz, and Wilde, $59 \mathrm{~S} \mathrm{Cal} \mathrm{L} \mathrm{Rev} \mathrm{at} 279$ (cited in note 48). 
nitive limitations. ${ }^{352}$ In describing the tradeoff of accuracy for reduced effort, why should we privilege the rationality of the exchange over the cognitive limitations that make the tradeoff necessary? In the end, the question of whether boundedly rational decisionmaking demonstrates "rationality" or "cognitive limitation" is incoherent; the answer is "both."

Ultimately, it is important for legal scholars not to become too bogged down in the philosophical question of whether bounded rationality is or is not "rational." Human decisionmaking is what it is, and the challenge of primary importance is not how to classify it but how to devise appropriate legal institutions in response. The large body of evidence that human decisionmaking and choice deviates systematically from the usual law-and-economics assumptions of utility maximization, self-interest, and (often) wealth maximization, ${ }^{3.4}$ requires consequentialists to replace their default preference for unregulated private markets ${ }^{355}$ with a greater initial agnosticism concerning the relative institutional competence of markets and government intervention. Both markets and various government institutions will be imperfect, and the question of which - or what combination of the two-has the greatest likelihood of promoting human happiness needs to be approached on a case-by-case basis. The fact that individuals acting alone in an unregulated market are unlikely to maximize the satisfaction of their preferences does not suggest, of course, that government will make matters any better. But it does suggest that it is not obvious a priori that government will make matters worse. The careful and creative use of legal institutions has the potential to be beneficial.

In the case of standard form contracts, buyer bounded rationality suggests that the enforcement of all form terms will not create socially

352 See, for example, Bettman, Luce, and Payne, 25 J Consumer Rsrch at 193 (cited in note 51) (noting that limited processing capacity means that consumers must be selective in their use of information).

353 Attempting to avoid this precise definitional debate, Herbert Simon described boundedly rational decisionmaking as "reasonable" but not "rational." See Hogarth, Judgement and Choice at 63 (cited in note 58).

354 See generally Korobkin and Ulen, 88 Cal L Rev at 1060-70 (cited in note 49) (describing different conceptions of rational choice theory).

355 See, for example, Ware, 56 U Chi L Rev at 1483 (cited in note 151) (claiming that inefficiencies created by the free market "are probably less than those that would result from government intervention"). Gerd Gigerenzer contends that bounded rationality cannot properly be labeled optimization under constraints or the manifestation of cognitive limitations, but rather bounded rationality is "ecologically rational" behavior that emerges from the structure of the human mind and the structure of the environments in which the mind operates. See Peter $\mathrm{M}$. Todd and Gerd Gigerenzer, Bounding Rationality to the World, $24 \mathrm{~J}$ Econ Psych 143, 145-48 (2003); Gerd Gigerenzer, Striking a Blow for Sanity in Theories of Rationality, in Mie Augier and James G. March, eds, Models of a Man: Essays in Memory of Herbert A. Simon (forthcoming 2004). 
optimal contracts or contracts that are optimal for buyers. Government design of contract terms, either ex ante or ex post, is likewise an imperfect option. The best approach is an amalgam of market and government institutions, with each institution favored when its relative competence is greatest. The design of salient contract terms is best left to the private market because sellers have profit incentives to draft efficient terms. The design of non-salient terms is better assigned to government institutions because the market will not create pressure toward efficiency and state actors, as imperfect as they will be, at least can aim at the proper target. When the costs and benefits of particular terms are substantially similar across the range of contractual contexts in which the term will appear, legislatures and/or agencies mandating terms ex ante have a competitive advantage over courts; when costs and benefits are highly context specific, the advantage is reversed. In the latter circumstance, a judicial review process based upon a modified application of the unconscionability doctrine can improve upon the status quo and can be accomplished legitimately within the legislated boundaries of that doctrine.

An appreciation of buyer bounded rationality should undermine confidence that unregulated markets will force sellers to provide the efficient level of any type of product attribute - not merely form contract terms. The policy prescriptions presented in this Article are tailored to its particular subject matter, however, and extensions of the argument to claim that increased regulation of non-term product attributes is warranted should be made cautiously, for two reasons.

First, particular characteristics of non-term product attributes might make market failure relatively less likely than in the case of form terms. For example, other types of attributes might be more likely to be salient because they are more important to buyers, do not concern low-probability occurrences, do not present emotion-laden tradeoffs, or are not as difficult to compare across sellers. ${ }^{3.6}$ Alternatively, sellers might be better able to make non-term attributes salient through advertising, or sellers who provide such attributes of inefficiently low quality might suffer a greater risk of reputational harm.

Second, the institutional competence of government institutions (legislatures, administrative agencies, and courts) to determine nonterm attributes might be different than their competence to determine contract terms. Legislatures and agencies might have a greater ability to mandate some types of product attributes - health and safety features, for example - than others. Although judges usually enforce form contract terms as written, courts have always reviewed such terms, and

356 See generally Part II.C.2.

357 See generally Part II.E. 
the established doctrine of unconscionability provides a ready tool for this endeavor. Courts are not in the habit of reviewing the acceptability of many other product attributes (again, safety attributes might be an exception), and this likely would raise questions concerning their institutional competence to do so.

With these cautions noted, the logic of this Article does suggest a need for further analysis of the relative institutional competence of markets and regulation in a variety of contexts beyond the particular issue of form contract terms. 


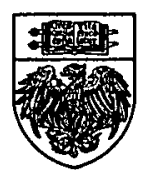

